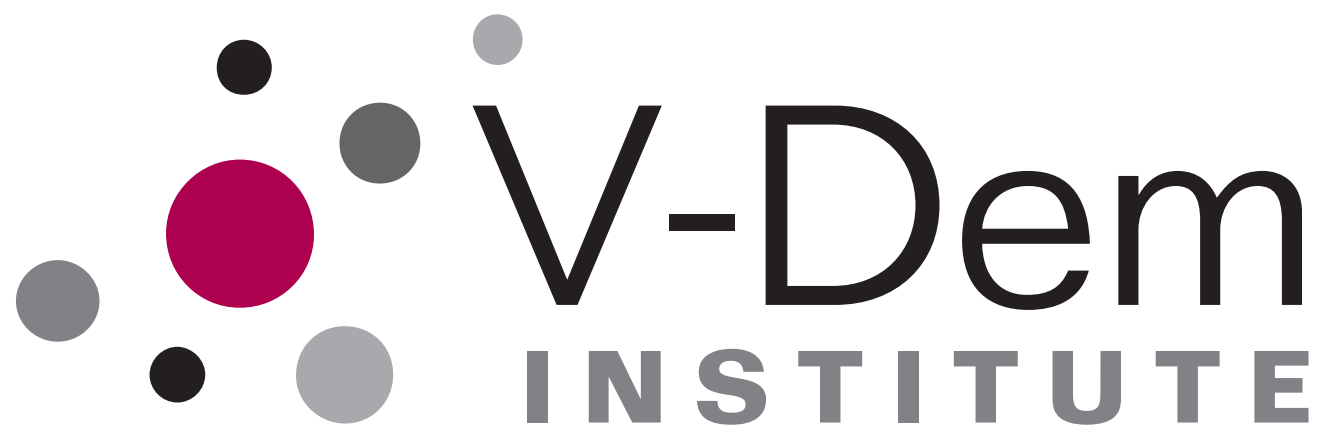

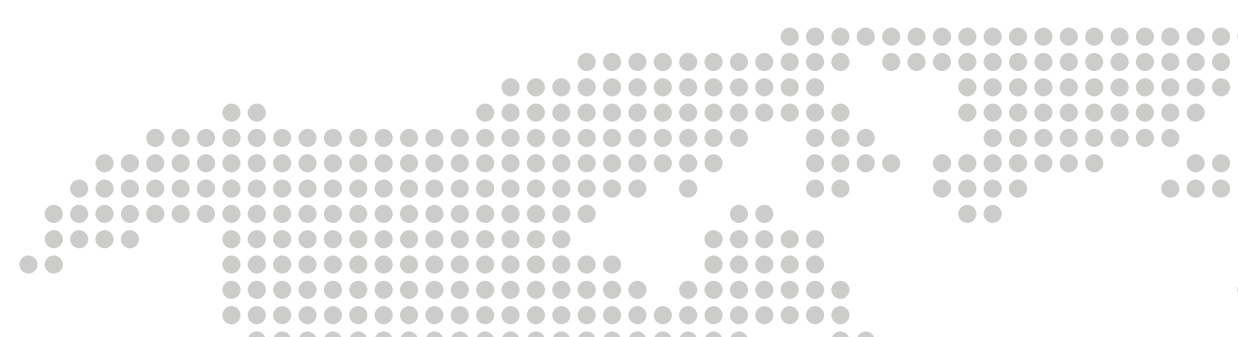

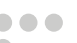

:
0000000 190000000 0

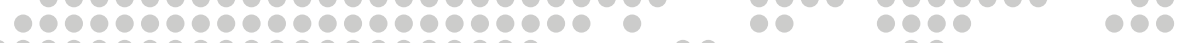

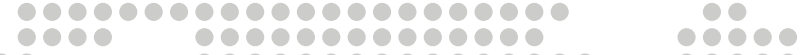

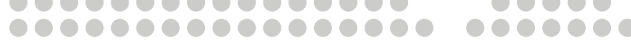
0000000000000000000000000

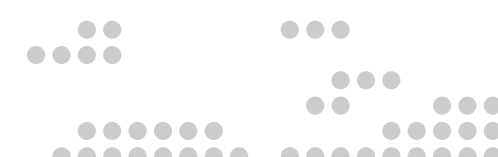
ores 1080

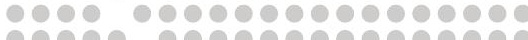

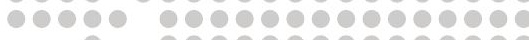
100

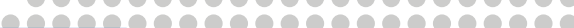

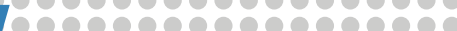

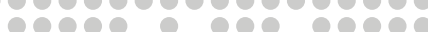
riber

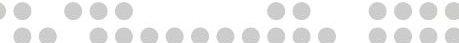

Party Institutionalization and Welfare State Development

Magnus B. Rasmussen Carl Henrik Knutsen

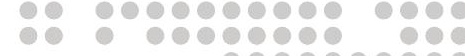

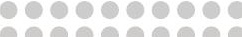

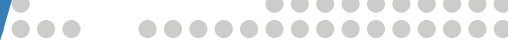

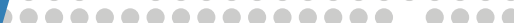

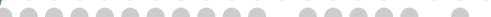

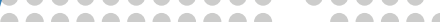

ropos or

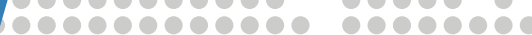

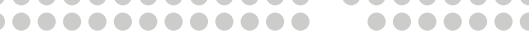
100000000000000000 100000000000000

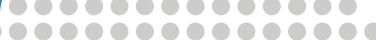
30000000000000000000

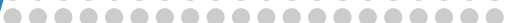
00000000000000000

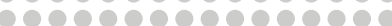



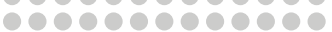
100
00000000

0000000

000000

090000

10000

000

000

10

10

O

0

00000000000

0000000000

000000000

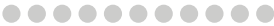

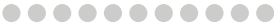

90900000000

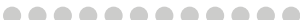
оере8е

6е88080

0000000

0000000

100000

000000

1000

100 
Varieties of Democracy (V-Dem) is a new approach to conceptualization and measurement of democracy. It is co-hosted by the University of Gothenburg and University of Notre Dame. With a V-Dem Institute at University of Gothenburg with almost ten staff, and a project team across the world with four Principal Investigators, fifteen Project Managers (PMs), 30+ Regional Managers, 170 Country Coordinators, Research Assistants, and 2,500 Country Experts, the VDem project is one of the largest ever social science research-oriented data collection programs.

Please address comments and/or queries for information to:

V-Dem Institute

Department of Political Science

University of Gothenburg

Sprängkullsgatan 19, PO Box 711

SE 40530 Gothenburg

Sweden

E-mail: contact@v-dem.net

V-Dem Working Papers are available in electronic format at www.v-dem.net.

Copyright (C) 2017 by authors. All rights reserved. 


\title{
Party Institutionalization and Welfare State Development ${ }^{*}$
}

\author{
Magnus B. Rasmussen \\ Institute for Social Research, Oslo Norway \\ Department of Political Science, University of Stavanger \\ Carl Henrik Knutsen \\ Department of Political Science \\ University of Oslo
}

\footnotetext{
* We would like to thank Svend-Erik Skaaning, Francesc Armat, Kalle Moene, Lars Svåsand, Georg Picot, Henning Finseraas, Bjørn Høyland, Johannes Lindvall, Haakon Gjerløw, Anders Sundell, Carsten Jensen, Andreas Kotsadam, Tore Wig, Sirianne Dahlum, and attendees at the Conference for Global Challenges - Nordic Experiences, University of Oslo, 21 March 2017, at SAMPOL institutional seminar, Department of Comparative Politics, Bergen University, 19 April 2017, the Carsten Jensen seminar, Institute for Social Research, Oslo and the American Political Association Annual Meeting 2017, San Francisco for very helpful comments and suggestions. This research project was funded by the Research Council Norway, "Young Research Talent" grant, pnr 240505, PI: Carl Henrik Knutsen. Rasmussen's work was founded by the Research Council Norway "TREfF" grant, pnr 257603. Knutsen's work on this research project was also supported by Riksbankens Jubileumsfond, Grant M13-0559:1, PI: Staffan I. Lindberg, V-Dem Institute, University of Gothenburg, Sweden
} 


\begin{abstract}
We propose that the extent to which political parties are institutionalized shapes welfare state development. Institutionalized parties allow politicians to overcome coordination problems, avoid capture by special interests, and form stable linkages with broad social groups. These features both enable and incentivize politicians to pursue generous and universal welfare policies. Employing recent measures of party institutionalization and welfare law features, we test implications from our argument on data covering 169 countries and extending back to 1900 . Even when accounting for country- and year-fixed effects and institutional features such as electoral system, regime type and state capacity, we find robust evidence that party institutionalization leads to more extensive, universal, and generous welfare arrangements. The relationship is more pronounced in democracies, but exists also in autocracies. When disaggregating party institutionalization and evaluating mechanisms, the linkages that institutionalized parties form with social groups constitute one important, but not the only relevant, factor.
\end{abstract}




\section{Introduction}

We argue that political parties more strongly prefer and have better capabilities to provide encompassing, generous, and universal welfare policies if they are highly institutionalized. By detailing this argument and putting its implications through demanding tests on extensive data material, we link different central patterns observed by scholars of political development:

One key feature of political development during the $20^{\text {th }}$ century was the increased prevalence of policies pertaining to most, if not all, citizens within the boundaries of the state. From education to health care to pensions, new policies arose to cover needs of the broader population, and not only narrow elite groups or people living in a particular region (Huntington, 1968; Lindert, 2004). Policies, in various areas, turned more universal. Concurrently, politics in many countries also turned more universal, both regarding which social groups participated in public decision making and regarding geographical scope, with a shift in emphasis from the local to the national level in many countries (see Somanathan 2001). The capacity of many states increased (Fukuyama, 2015), suffrage was expanded (also in countries where elections were far from free and fair; e.g., Miller, 2015) and new constitutions and various national-level institutions were developed (e.g., Elkins, 2010). Key in this process was the development of political parties competing and otherwise operating on the national arena, both in democratic (e.g., Mainwaring \& Scully, 1995; Schattschneider, 1942) and many autocratic countries (e.g., Geddes, 1999; Magaloni, 2006).

Despite these broad trends, countries across the world differ in the scope and depth of universalistic policy making (Mares \& Carnes, 2009; Scruggs \& Allan, 2008). Differences in national-level institutions, such as competitive elections and franchise rights (e.g., Acemoglu \& Robinson, 2006; Boix, 2003; Lindert, 2004), the electoral system (e.g., Jurado \& Leon, Forthcoming; Persson \& Tabellini, 2004; Rogowski, 1987), or state and administrative quality (e.g., Orloff \& Skocpol, 1984; Rothstein, Samanni, \& Teorell, 2012) help explain this variation. Adding to these insights, we highlight that features of political parties also play a key role:

Party institutionalization, we argue, enables parties to widen their circle of constituents, elicit and aggregate information about constitutents' demands, and bargain and overcome veto players inside and outside the party organization. These features shape both the incentives and the capabilities of parties to adopt universal social policies (in different areas). Our proposed mechanisms involve both "bottom-up" processes, related to how institutionalized parties filter information and aggregate the preferences of broad constituencies into national politics, and "top 
down processes", related to how such parties transform local demand into national policy solutions and effectively implement these, even in the face of opposition by narrow interest groups.

In proposing our argument, we pursue an institutionalist approach that combines mesolevel theorizing - centering on the institutions of parties, the incentives of politicians, and their relationships with key constituencies - with macro-level implications. Building on previous work on candidate capture by narrow or local interests (Ehrlich, 2007; Martin \& Swank, 2008), dominant regime parties (Kim \& Gandhi, 2010; Magaloni, 2006), programmatic versus clientelistic party linkages (Kitschelt, 2000; Shefter, 1977), and risk as a source of welfare demand (Moene \& Wallerstein, 2001), we develop a novel argument on how institutionalized national parties contribute to encompassing (in terms of risk areas covered), universal, and generous welfare states.

Recent datasets with relevant measures of party institutionalization and of national welfare policies allows for testing our hypotheses on extensive data material - covering most countries globally, back to 1900. Thus, we can also investigate how well the theorized relationships travels across space and time, and conduct demanding tests by, e.g., controlling for country- and yearfixed effects. The relationships between party institutionalization, on the one hand, and encompassing, universal and generous welfare state policies, on the other, turn out highly robust. They also appear strong in quite different contexts, including in both democratic and autocratic regimes, although the relationship is stronger in democracies. The results hold up when accounting for different plausible alternative explanations, for example concerning how electoral systems, working class parties and organizations, civil society participation, or state capacity shape welfare state development.

In Section 2 we discuss the concept of party institutionalization and review relevant literature, before we detail our argument. In Section 3 we describe data sources, measures, and research design. Section 4 contains the empirical analysis, whereas Section 5 concludes with a discussion on how our study contributes to hitherto distinct literatures. 


\section{Theory}

\section{Party institutionalization}

The literature on political parties distinguishes two key aspects of party systems, namely their internal and external characteristics (see Bernhard et al., 2016, p. 5). The external dimension is often captured by the concept of "party system institutionalization" (e.g., Hicken, Kuhonta, \& Weiss, 2015) highlighting features such as how stably aligned voters and legislators are to particular parties. We focus here on the internal dimension, often referred to as "party institutionalization".

When parties are institutionalized, decisions within parties are taken according to clear, stable rules and informed through well-organized contact points and networks linking party elites with broad constituencies outside the core organization. Thus party institutionalization implies the allocation of decision making power to core, national-level party institutions, well-specified and organizationally determined roles for decision-makers, hierarchical arrangements that allow, e.g., for disciplining actors that stray from the party line, organizational complexity that allows for division of labor and effective outreach to different geographical areas, and mass constituencies aligned with the party through relatively stable forms of linkages, typically built around a clearly expressed policy program.

Optimally, measures of party institutionalization should reflect this broad and multifaceted concept (and that parties could score relatively low/high on different features). More specifically, measures should capture 1) different features of party organizations, including the core national organization and the existence of branches operating throughout the territory, 2) how parties function in coordinating and disciplining key actors aligning with the party and 3) how parties link up to constituencies outside the core organization. (We return to issues of measurement in Section 3).

When parties lack these traits, we consider them to have low degrees of institutionalization, and decision-making power thus rests elsewhere than in the party organization, typically in the hands of particular individuals or narrow social groups. (The same holds true also in polities that lack political parties entirely). One example is "personalized rule" (e.g., Geddes 1999) where the leader, and his/her closest friends and family, sometimes exercise power in a near-monopolistic manner, even if the leader formally belongs to a political party (see also Bernhard et al. 2016). 
As Bernhard et al. (2016) observe, studies on parties, party systems and institutionalization occur in two largely parallel literatures on parties in democracies and autocracies, respectively. Regarding the first, political scientists have long proposed that parties play crucial roles in affecting the functioning and stability of democracies (see, e.g., Huntington, 1968; Schattschneider, 1942). More recent work has highlighted how parties shape economic and other policies, also those pertaining to public goods provision (Croissant \& Volkel, 2012; Hicken, Kollman, \& Simmons, 2016; Hicken \& Simmons, 2008; Kitschelt, 2000; Kitschelt \& Kselman, 2013; Levitsky, 1998; Randall \& Svåsand, 2002). Indeed, a handful of studies have studied features of parties, in democracies, and outcomes fairly closely related to those we analyze below: While studying the nationalization of party systems (in terms of their distribution of votes across the territory) rather than the institutionalization of parties, Jurado (2014) finds that this feature relates positively to social spending. Further, the domination of parties by activist as opposed to leadership has been linked to welfare state retrenchment (Schumacher, 2012; Schumacher, De Vries, \& Vis, 2013).

Regarding the second literature, several studies propose that parties in autocracies have important consequences for outcomes such as political stability and regime change (e.g., Boix \& Svolik, 2013; Brancati, 2014; Brownlee, 2009; Magaloni, 2006; Svolik, 2012). Further, (regime) party features influence which policies are pursued, and subsequent outcomes in areas such as investment or economic growth (Gehlbach \& Keefer, 2011; Keefer, 2007; Wright, 2008).

Yet, we follow Bernhard et al. (2016), who study the relationship between strong parties and economic growth, in contending that - at an abstract level - many (though not all) features associated with party institutionalization are fairly comparable across (regime) contexts and may have quite similar effects on policy-making. As we expand on below, we expect that some of the noted features of party institutionalization affect welfare state policies in the same direction in both democracies and autocracies, while other features should play a more prominent role in democracies. Yet, we highlight that our theory moves at a general level, and that we do not exclude that there are other, relevant moderating factors, such as governing party ideology. ${ }^{1}$

\footnotetext{
${ }^{1}$ In general, "left-leaning" parties in government may be more eager to expand welfare state arrangements. But, some of the mechanisms that we discuss below are expectedly at work also for institutionalized "right-wing" parties that form linkages with fairly broad social groups (in addition to rich, narrow groups such as large-scale landowners). Especially for life-course related risks such as old-age or sickness, both low and high income workers are likely to demand insurance (Esping-Andersen, 1999); employees are likely to become sick or old (unlike, e.g., unemployment risks which are more class- or occupation-dependent). Hence not only working-class parties face demands to introduce welfare policies. We leave a thorough discussion and systematic study of moderating factors pertaining to ideology and identities of social groups to future research. But, we account for, e.g., government ideology in our robustness tests.
} 


\section{The incentives and capabilities of parties to pursue social policies}

Citizens face various types of economic risks, particularly as workers: Since most people are risk averse they often prefer policy-makers to alleviate these risks (see, e.g., Moene and Wallerstein 2001). With comprehensive social and economic developments - such as industrialization, urbanization and the opening up of closed sectors to trade - often come demands that parties implement policies to deal with the increased risks that these processes entail (Mares, 2005). These demands can, however, be met by quite different kinds of policies. For example, demands for parties to deal with risks related to involuntary unemployment can be met by local constricted schemes, such as workfare programs at the municipality level. Alternatively, policy-makers can introduce national schemes, thus also covering citizens living in areas where local schemes are not adopted. We discuss below how political parties vary in their incentives to create national welfare states that encompass multiple risks and in how capable they are in effectively implementing them.

Yet, even if parties decide that a nation-wide social policy is desirable, the choice of who is to benefit remains. Should the program only cover a specific part of the workforce (such as public servants or manufacturing workers in one sector), should it be means-tested and strictly targeted to the poor, or should benefits accrue to all citizens? When political parties depend on narrow interests for electoral success or, more generally, for maintaining office, a relatively effective strategy is to introduce particularistic policy measures that channel resources to these groups instead of universal measures (which advantage also large groups of politically irrelevant citizens). This logic is applicable to a range of policies (Bueno de Mesquita, 2003), but social policy programs are particularly relevant instances (see Knutsen \& Rasmussen, fortchoming). Parties with broader constituencies should, everything else equal, prefer more universal programs than parties relying on narrower constituencies, either geographically - in which case local programs may be preferred - or particular social groups - in which case national programs may be targeted on these groups (e.g., Haggard \& Kaufman, 2008; Knutsen \& Rasmussen, fortchoming; Shefter, 1977).

In addition to the preferences over policy designs, the capacity of political actors to develop and implement effective policies matters for outcomes. While a party might want to focus on national solutions to work-life risks, it could still be unable to pursue such policies effectively. There may be different reasons for this, including a lack of capacity to control the behavior of candidates, who sometimes face strong incentives to renegade from the party line (Ansolabehere, 
Snyder, \& Stewart, 2001), or an insufficient organizational apparatus for eliciting information about what a viable policy design looks like in practice.

Given these hurdles, we cannot assume that all parties are likely to favor, or have the ability to handle, various citizens' demands for risk-mitigating schemes through national-level universal social policies (see also Kitschelt 2015). Moreover, even in cases where broad-based coverage of various risks is in place, the generosity of the program can vary dramatically. In some instance de jure, programs may either be de facto inoperative or only channel limited resources to those formally entitled to benefits (Rasmussen, 2016). Below, we detail how differences in party institutionalization contribute to explain variation in the extensiveness, universality, and generosity of national welfare policies.

\section{Why institutionalized parties lead to welfare state development}

Our theory consists of two parts, and both link (different) features of party institutionalization to the incentives and capacities of parties to pursue universal welfare policies in various areas. In the first, "bottom-up" part of the argument, we focus on how demands from groups of citizens are aggregated up into the party system. We also discuss how demands from organized interests such as unions or employer associations will be treated differently depending on level of party institutionalization. The second, "top-down" part addresses how institutionalized parties can override particular political elites or social groups that may act as veto players (e.g., Huber and Stephens 2001; Tsebelis 2002) on implementing comprehensive (and expensive) welfare legislation.

Regarding bottom-up mechanisms, parties differ in how well they can predict and aggregate voter preferences (see, e.g., Kim \& Gandhi, 2010; Magaloni, 2006). We highlight how institutionalized parties establish local branches and linkages with civil organizations such as trade unions or religious organizations. These formal organizational and network features are vital for effectively catching and interpreting the needs and demands of broad (and quite different) groups of citizens. Institutionalized parties, in both autocratic and democratic contexts, tend to establish such linkages, even if the more specific motivation for the party could be co-optation of potentially revolting industrial workers under autocracy and voter mobilization under democracy (Kim \& Gandhi 2010, 648). Let us elaborate:

Parties with extensive systems for preference aggregation are more likely to register signals from a broad array of groups. When parties create strong national organizations and 
extensive local branches, they become identifiable focal points for members and various voters, enabling parties to interact also with disadvantaged groups of workers such as land workers or unskilled urban workers in service industries (such groups are numerous in most countries, see Ansell \& Samuels, 2014). Institutionalized parties are also likely to establish connections to broad civil society organizations, one example being trade unions, allowing these organizations to signal their preferences (Kitschelt 2013). When parties have weak preference aggregation systems (or when parties are absent), the voices of less resourceful citizens tend to go unnoticed. In the absence of strong national organizations and local branches, parties are less likely to learn the preferences of citizens in diverse and distant regions, allowing elite groups with more resources, who presumably do not want to pay for universal and generous social policy programs, to overshadow broader and less resourceful groups (see, e.g., Przeworski, 2010).

Given the accountability links between political agents and voters - especially the need for broad support to win re-election in competitive multi-party contests - we anticipate such bottom-up mechanisms to be particularly strong for institutionalized parties in democracies. Yet, as we discuss below, we anticipate them to be at work (although to a lesser extent) also in autocratic contexts.

Demands from the local interests must, however, be adjusted and weighted against the ideological position of the party as whole. Institutionalized parties will try to represent different local groups, but do so with national solutions (Hicken, Kollman, \& Simmons, 2016). This expectation partly stems from the notion that institutionalized parties with local organizations are better able to separate signals from noise, and their information-processing capacities make them less likely to overly focus on one particular signal. Organizational complexity, in the form of permanent, strong local and national organizations and dense civil society connections, are vital for parties to be informed by, and be able to aggregate, the preferences of various unorganized and organized interests.

Conversely, absent any form of parties linking leaders to the preferences of mass constituencies, such as under many monarchical or military regimes, or when party organizations are weak, leaders may prefer discretionary spending on private goods to their narrow support coalition (Bueno de Mesquita 2003). Welfare policies in instances of low party institutionalization should thus be non-existent, or, when they exist, concentrated to key, narrow groups that the regime truly needs to co-opt, such as military officers. 
Regarding top-down mechanisms, they relate to the importance of party institutionalization for effectively disciplining individual candidates as well as overpowering - or striking deals with - powerful social groups opposing the introduction of welfare schemes.

In many political systems, several politicians or social groups have the standing to de facto veto legislation or implementation of new policies that do not serve their interests (e.g., Ehrlich, 2007; Tsebelis, 2002). One example of a group that could lose out from the enactment of, e.g., a universal unemployment benefits system is large-scale landowners, who anticipate taking much of the associated tax burden but little of the benefits (Ansell \& Samuels 2014). Individual members of parliament (MP) with a formal affiliation to a party, but with an independent power base and diverging policy preferences, can also act as veto players. When facing such MPs, who often prefer working for targeted policies benefiting their personal constituency, the ability to call on party discipline is key for enabling national and universal policy solutions.

How can parties, which may gain electoral or other benefits from pursuing universal welfare policies, overcome such veto players? We propose several mechanisms through which institutionalized parties can overcome resistant social groups or individual politicians with strong incentives to stray from the party line (see also Bernhard et al. 2016):

First, institutionalized parties should avoid renegade politicians through screening candidates according to, e.g., their ideological position and tendency to be opportunistic. Wellestablished, party-centered selection processes, focusing on shared ideology, should help in ensuring party unity (Carreras, 2012). Second, institutionalized parties are enduring. Insofar as this is known by all relevant actors, political actions should be taken with at least one eye towards their long-term consequences. When this is combined with a well-functioning organizational apparatus, which provides fora for bargaining and tools for subsequent monitoring, party leaders, individual politicians and other powerful actors can strike comprehensive "deals that involve intertemporal tradeoffs and [enforce] those deals through time" (Bernhard et al., 2016, p. 8; see also Boix \& Svolik, 2013; Gerring \& Thacker, 2004; Hicken \& Simmons, 2008; Svolik, 2008). ${ }^{2}$ Thus, even if individual parliamentarians, for example elected from very wealthy or rural districts, should oppose comprehensive, universal welfare legislation, a stable institutionalized party may

\footnotetext{
2 In democracies, institutionalized parties adopting long time-horizons may also affect whether future welfare payments are perceived as credibly by voters. If voters can choose between receiving an immediate good (e.g., reduced taxes or discretionary short-term payments) or an insurance against some possible future risk (a welfare benefit), the credibility of the promises of the latter is key (Iversen, 2005). If parties are either unable to carry forth policy promises, or can be easily swayed to shift policy, voters will have little incentives to vote for parties that promise future welfare benefits; parties that promise, e.g., tax reductions are more likely to be the preferred alternative. This suggests that institutionalized parties (in democracies) have stronger electoral incentives to expand welfare programs than non-institutionalized parties
} 
allow party leaders to bring on board such politicians by credibly promising other policy- or personal gains. In sum, institutionalized parties should be better able to overcome veto points and build broad coalitions behind generous, universal welfare policies.

Finally, institutionalized parties, with their streamlined national and subnational organizational apparatuses, help with effectively implement comprehensive welfare policies. We discussed above how institutionalized parties can elicit and process information from different groups. The very same informational capacity, resting in effective operations on the ground and a well-functioning national organization to aggregate information, should allow institutionalized parties to transform these demands into policies that are amenable to effective implementation, for example by taking into consideration different practical obstacles for registration of beneficiaries and monitoring of payments. Conversely, if weakly institutionalized parties anticipate that they lack the informational and organizational apparatus for properly designing and implementing (costly) welfare schemes, they may not risk their "political capital" on such ventures.

\section{Expectations and scope conditions}

The discussion above suggests three general hypotheses:

H1) Countries where parties are generally more institutionalized develop more encompassing (in terms of risks areas covered) welfare states than countries with less institutionalized (or no) parties.

H2) Countries where parties are generally more institutionalized develop more universal welfare policies than countries with less institutionalized (or no) parties.

H3) Countries where parties are generally more institutionalized develop more generous welfare policies than countries with less institutionalized (or no) parties.

While our theoretical argument suggests that party institutionalization should affect the three features of welfare states in tandem, testing the three hypotheses separately provides a stronger overall test for our argument. It is less likely that any spurious factor should drive three relationships, which are all predicted by our theory, than one (specific or composite) relationship.

The "standard context" studied by the welfare state literature is the early industrialized and highly developed OECD democracies (see Haggard and Kaufmann 2008). Much of this 
literature has focused on working class parties (and trade unions) as agents of welfare state development, and is inextricably linked to the historical rise of these organizations and movements in these mostly Western European countries. ${ }^{3}$ Yet, the differences in party organization, stability and links to voters that we have highlighted differ, and should matter, both within developed and developing countries.

The features of parties that we focus on differ also between relatively democratic regimes and between relatively autocratic regimes. Yet, we anticipate that the theorized relationships between party institutionalization and welfare state features should be somewhat stronger in democracies than in autocracies. Some of the proposed bottom-up mechanisms presumably operate more strongly in democracies, as the fortunes of politicians are more clearly linked to demands by broad groups of constituents through contested elections. Still, many autocratic regimes hold multi-party elections, and although these elections are not always contested (e.g., Levitsky \& Way, 2010) autocratic regime parties still care about mass demands for various reasons (see, e.g., Miller, 2015; Wintrobe, 1998). For example, industrial workers constitute one group has strong mobilization capacity (Kim \& Gandhi 2010) and could spearhead revolutions if disgruntled. Further, we fail to see any clear reason for why the top-down mechanisms should differ much between democratic and autocratic settings. For these reasons, we anticipate party institutionalization to matter for welfare state development also in autocracies.

We have thus laid out a theory of party institutionalization and welfare state features that should be relevant across different contexts (although we can certainly not exclude that there are relevant moderating factors, e.g. related to ideology or the specific identity of social groups linking up with institutionalized parties, as discussed). Hence, we will empirically assess our theory by employing samples that pool historical information from all countries with available information. Yet, this also makes it incumbent on us to assess empirically how generalizable our argument seems to be. While we cannot assess all relevant moderating factors, in part due to lack of comparable, cross-national data, we test for several relevant contextual factors that could moderate the proposed relationships between party institutionalization and welfare state features.

\footnotetext{
${ }^{3}$ Yet, even within this group of countries, the worker movements (comprising both unions and social-democratic parties) have never been strong enough to single-handedly shape politics (Bartolini, 2000). Still, even in states with few or weak left governments, universal welfare policies have been introduced to a surprisingly large degree, and the introduction of universal welfare arrangements in Scandinavia preceded the electoral rise of the left (Baldwin, 1990).
} 


\section{Data and Empirical Specification}

\section{Party institutionalization index}

We employ the V-Dem Party Institutionalization Index (PI) as our key independent variable. PI is presented in detail and validated in Bizzarro et al. (2017). Briefly, PI records features of the main parties in a political system (easing comparisons between, e.g., one- and multi-party systems), and assessments are thus made at the country-level. PI aims to capture "1) the scope of party institutionalization in a country, 2) the proportion of parties that reach a threshold of minimal institutionalization, and 3) variations in the depth of this institutionalization - focusing on the links parties establish with voters and elites." (Bizzarro et al. 2017: 2).

Being part of V-dem, PI covers more than 170 countries (see Coppedge et al., 2016a,b), with time series from 1900 to the present. V-Dem indicators are typically coded by five country experts on ordinal five-point scales (see Appendix Table A1 for question wording), before final scores, at the interval level, are aggregated by the V-Dem measurement model. This model leverages various types of information to account for differential item functioning and ensure cross-coder consistency, as well as cross-country and inter-temporal comparability (see Pemstein et al. 2017).

More specifically, PI draws on five indicators (Bizzarro et al., 2017: 6-9). v2psorgs, considers how many parties have permanent organizations. v2psprbrch considers number of parties with permanent local party branches. $v 2$ psplats concerns how many parties have publicly available, and distinct, party platforms (manifestos). v2pscohesv assesses the degree of party legislative cohesion, capturing the extent to which political elites submit to the position of their parties when voting on important bills. Finally, v2psprlnks considers the most common form of linkage between parties and their constituents, with clientelistic linkages assumed to signal a low degree of party institutionalization and programmatic policy linkages, assumed to reflect high party institutionalization. ${ }^{4}$

PI is aggregated by summing across standardized versions of these five indicators, and then normalizing the resulting additive measure to $0-1$ by using its cumulative density function. An additive index allows for partial substitutability between indicators, meaning that a low value

\footnotetext{
${ }^{4}$ Including the indicator on party-constituent linkages allows capturing the extent to which parties are firmly rooted as mass parties with (stable) links to wider constituencies, core to our argument (and the concept of party institutionalization; see Bizzaro et al., 2016 for a discussion). Yet, we discuss below how this indicator might generate concerns about conceptual overlap with our dependent variable, and conduct tests that purge the relationship for its impact.
} 
on one indicator can be compensated, but only partly, by high values on other (Goertz, 2006). The aggregation thus reflects our argument in that different aspects of party institutionalization, such as a strong central organization or stable links with mass constituencies, may have some independent effects on the outcomes of interest. ${ }^{5}$

Figure 1 shows that (average) party institutionalization increased throughout the $20^{\text {th }}$ century, but at different speeds - and starting from different levels - in different regions. Western Europe and North America have historically displayed comparatively high levels, and Africa and the Middle East comparatively low. East and South-East Asia experienced sharp increases after WWII, whereas Latin America experienced its sharpest increase in PI in the 1980s. Eastern Europe and Central Asia has experienced several periods of declining PI. When considering between-country- and within-country variation over time, the pattern is even more mixed. Figure 2 displays PI for four countries, from different regions, with very dissimilar trajectories. Norway has had high and fairly stable scores across the time series. The Philippines, in contrast, has experienced relatively low levels of PI, especially during American colonial rule and Japanese occupation, but also decades later during Marcos' strong-man rule. While PI spiked with democratization in 1986, it has remained comparatively low, and has dropped very recently. Botswana had extremely low PI under British colonial rule, but experienced a dramatic increase with de-colonization in 1966. Botswana's high PI score has persisted thereafter, under multi-party elections and a Botswana Democratic Party government. Bulgaria experienced increasing, and very high, PI with Communist rule after WWII. PI then declined with the fall of one-party rule and introduction of multi-party politics.

\footnotetext{
${ }^{5}$ We should thus expect a link between an indicator and welfare state outcomes even when controlling for the other indicators.
} 


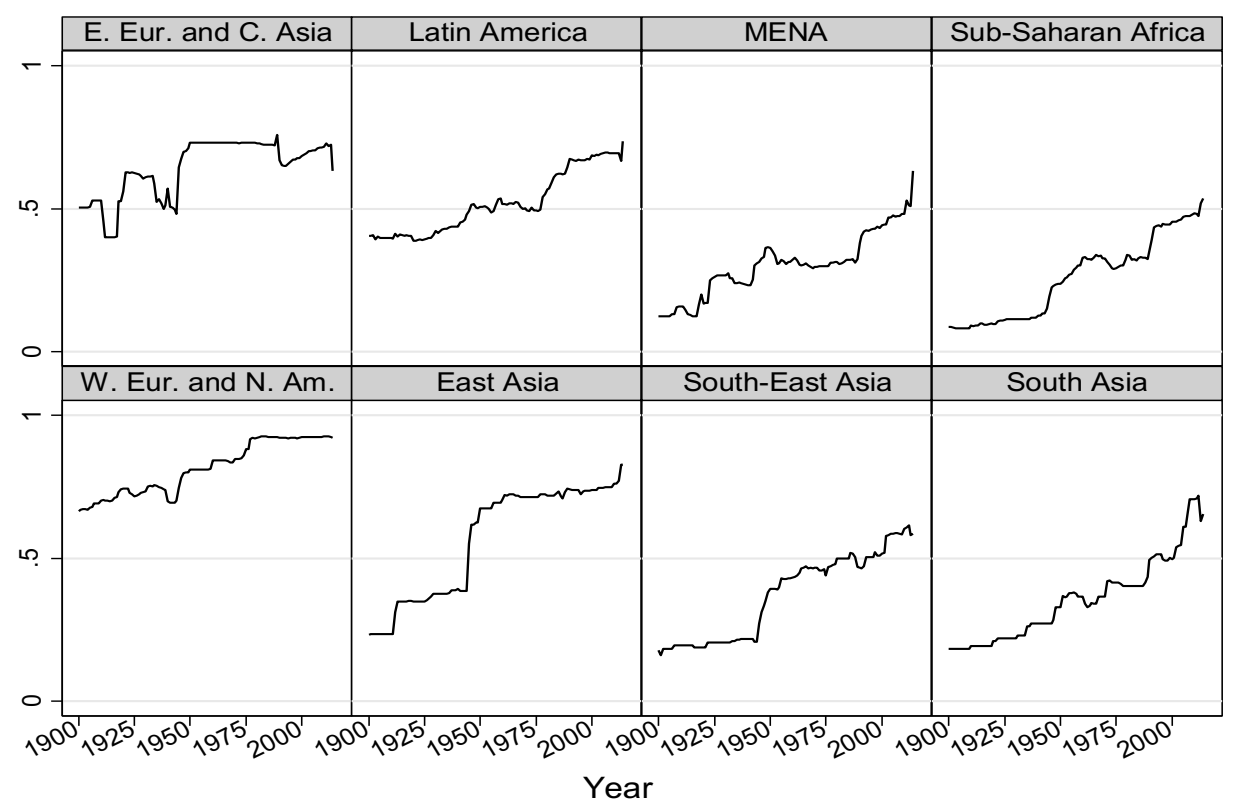

Figure 1: Average score on PI, over time, in eight world regions

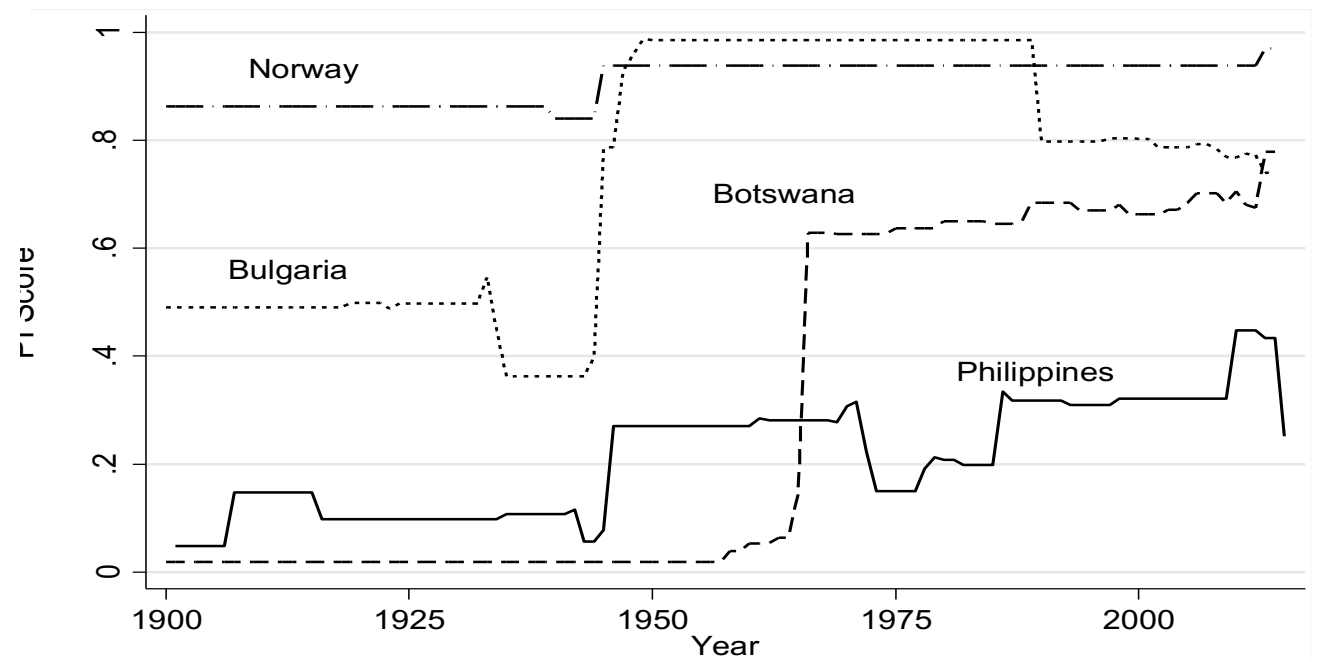

Figure 2: PI score over time in four selected countries

\section{Measures of welfare state features}

We have argued that party institutionalization should foster national, extensive, generous, and universal social policies, and, by implication, correlate negatively with local, targeted, or particularistic policies. No measure exists that properly captures all these dimensions together, except for over shorter periods of time (Scruggs, 2006). Instead, we employ several measures, compiled from various sources, to test the different implications separately. 
Our first measure is from the recent Social Policies around the World Dataset (SPAW), and captures how encompassing welfare states are in terms of risks covered. "Encompassingness" counts whether a major, national welfare law exists for each risk covered by SPAW, namely old-age, unemployment, maternity leave, child birth (family allowances), workinjury, and sickness. The operational criterion for a major program is that at least one of the following social groups are covered: agricultural workers; industrial/production workers; smallfirm workers; self-employed; students; employers; temporary/casual workers; family/domestic workers (for closer discussion, see Knutsen and Rasmussen forthcoming). Encompassingness thus ranges from 0 (no major program in any area) to 6 (major program in all areas). For the 9053 observations in Model 1, Table 1, the mean score is 3.4 and the median is 4 programs. Figure 3 shows the distribution on Encompassingness, sorted by quartile on our measure of party institutionalization, showing that number of major welfare programs is typically higher in observations with high scores on PI.

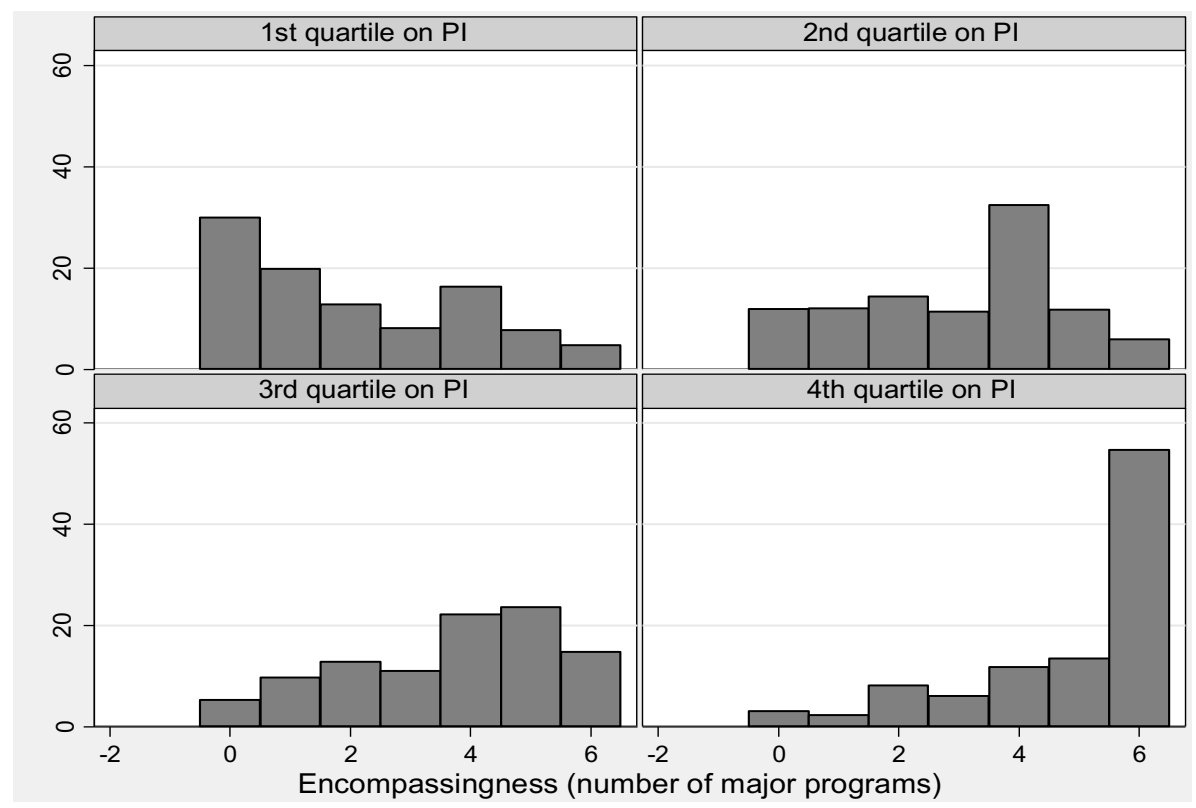

Figure 3: Histograms on Encompassingness for 9053 observations in Model 1, Table 1, by PI quartile.

In order to capture the extent to which welfare benefits are universal we use the v2dlunivl indicator from V-Dem, which purports to measure "[h]ow many welfare programs are meanstested and how many benefit all (or virtually all) members of the polity?" Beneficial for isolating the universalism dimension of welfare states, V-Dem expert coders are explicitly told not to score whether a welfare state is present or not, but instead the structure of what benefits exists. This 
means that $v 2$ dlunivl should not tap welfare state size $p e r s e .^{6}$ For the 16267 observations in Model 4, Table 1, the mean, median and standard deviations are, respectively, $-0.17,0.02$ and 1.47 . The lowest score is -3.26 and the highest is 3.23 . Figure 4 displays histograms for these observations, sorting the sample by quartiles on PI, and Figure 5 plots PI against v2dlunivl for two selected years. In general, countries have higher universalism scores when party institutionalization is high.

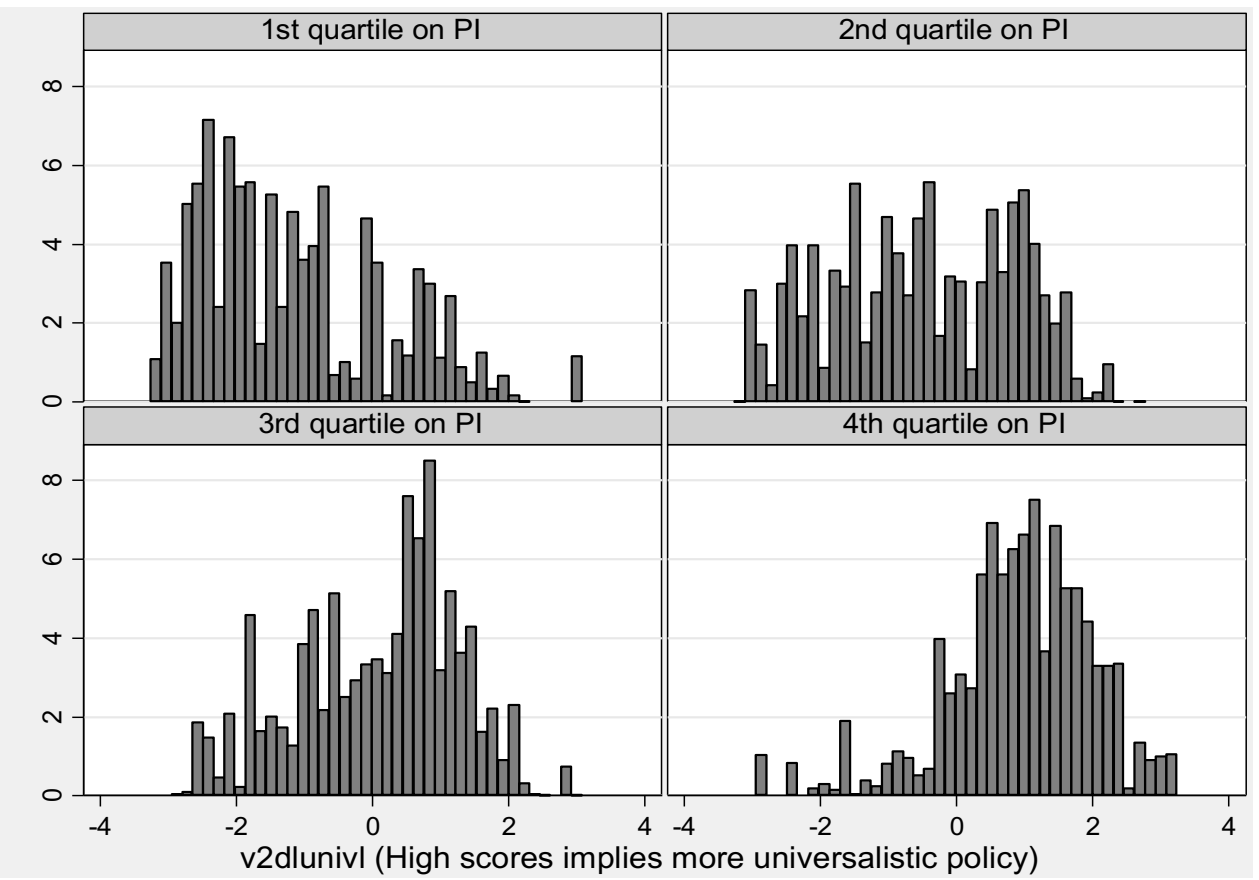

Figure 4: Histograms on v2dlunivl for 16267 observations in Model 4, Table 1, by PI quartile.

${ }^{6}$ We test the sensitivity of our findings to this assumption by controlling for number of major welfare policies enacted (Table A8). 

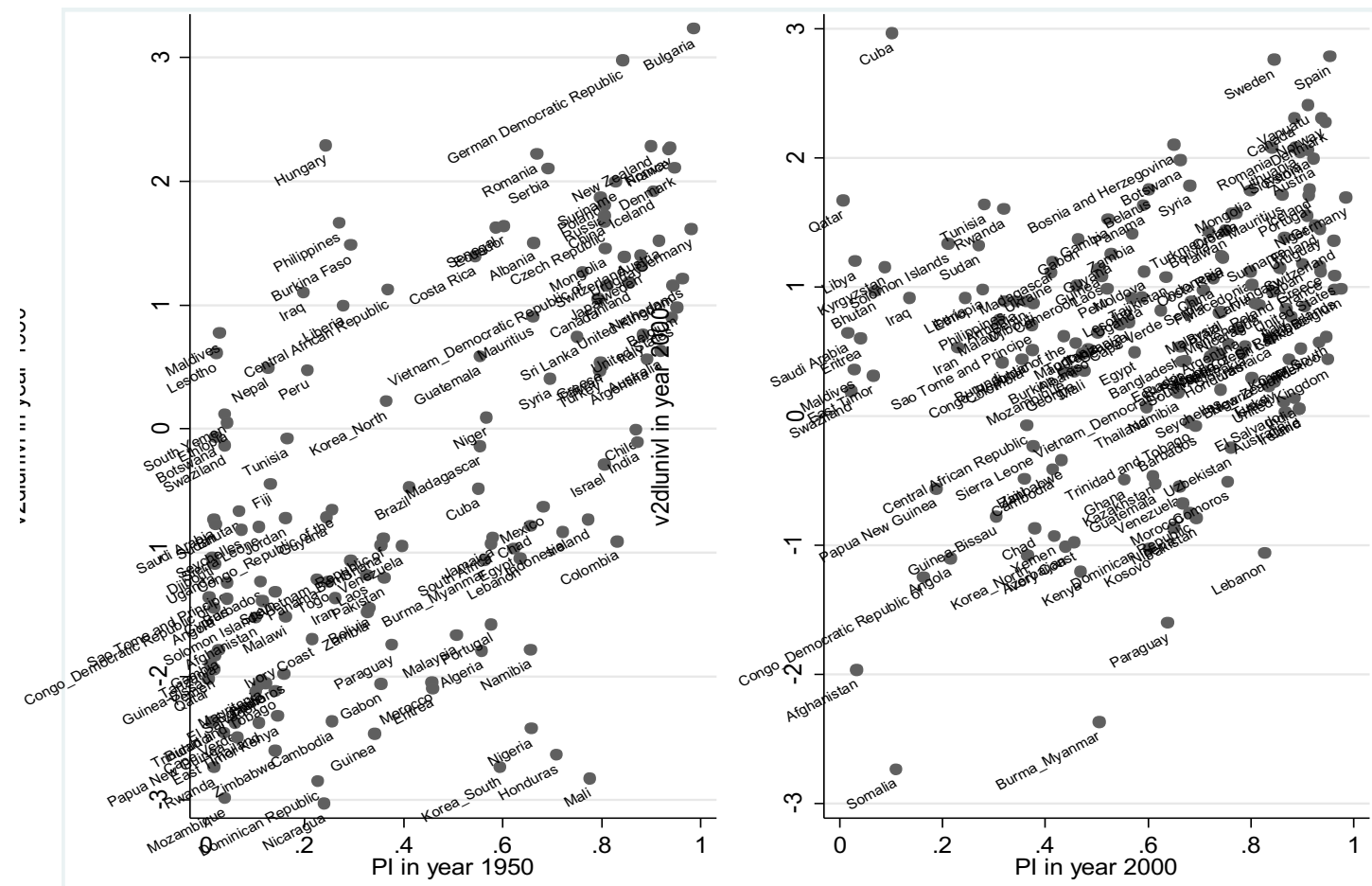

Figure 5: Scatter plots of PI and v2dlunivl in 1950 (left) and 2000 (right).

The encompassing risk coverage measure from SPAW and universalism measure from VDem are our two primary measures. Both allow us to include information from more than 150 countries and time series longer than 100 years. Yet, given concerns about PI and v2dlunivl both being drawn from V-Dem and potential resulting biases, which we discuss more closely below, we test two additional measures of universalism:

The first is the Universalism Index (UI) from SPAW, which also has extensive coverage. UI counts the number of social groups, as listed above, for each of the six major risk/policy areas in SPAW, and then aggregates over these areas. More specifically, 0 is given for a policy area if there is no major program; 1 if a program is means-tested based on some property criteria (income-based exclusions are not considered means-tested); 2 if one social group is covered by a contribution- or employment-based program; 3 if two groups are covered, etc. Finally, if the program automatically includes all citizens, 9 is given. Since there are six policy areas, and the programs are aggregated by addition, UI ranges from $0-54$. The second, from the SCIP-database (Korpi \& Palme, 2007), measures share of the work-force insured against illness in a state program. ${ }^{7}$ These data allow us to include only 21 countries (mostly the "old" OECD members), measured from 1930 to 2000.

\footnotetext{
7 We also test other proxies of welfare state universalism, such as V-Dem's "v2dlencmps" measure capturing segmentation, or the targeting of goods to particular groups.
} 
Unfortunately, data coverage is far more restricted for welfare program generosity, existing only for more recent decades and mainly developed OECD democracies. Replacement rates measure the ratio of an average worker's wage that would be replaced by the benefit, and is the most commonly used welfare state generosity measure (see Scruggs 2006). The CEWD (Scruggs 2006) and SCIP (Korpi \& Palme, 2007) datasets both provide replacement rate data. While CEWD reports data on a yearly basis from 1971 to 2012 for 22 countries, SCIP reports data for the 1930s, but at five-year intervals from 1950, for 20 countries. SCIP thus allows us to capture important pre-World War II developments, but we lose year-to-year variation. In the appendix, we display results using both datasets, but in the paper, we only focus on the SCIP data reflecting that we prioritize including historical variation. We also probe models using Social expenditure/GDP from Armingeon et al. (2017) as a (very) rough proxy of overall welfare state generosity.

\section{Control Variables and Benchmark Model}

Our benchmark model is an OLS estimator with panel corrected standard errors to account for panel-specific heteroskedasticity and autocorrelation. We always include country- and year-fixed effects. The country-fixed effects allow controlling for factors that are hard to observe and fairly stable within countries (national party culture, ethnic composition, specific colonial history, geographical features such as natural harbors that induce trade, etc) and that may simultaneously determine both party institutionalization and social policy. Including country-fixed effects is made feasible by the long time series and the substantial within-country variation in PI; the within-country standard deviation is 0.18 , not far from the 0.26 between-country standard deviation. The year-fixed effects allow us to account for any global time trends in party and welfare state development and common "shocks", such as ILO-conventions, global economic depressions, and world wars.

One complicating feature is the (presumably) complex causal relationships between PI and other observable factors that may affect welfare state development. Take income level, where one can plausibly argue that wealthier countries have advantages in allowing for more institutionalized parties (e.g., Kitschelt \& Kselman, 2013) and better opportunities to finance encompassing welfare schemes. This suggests that we should control for income. Yet, extant work also finds that party institutionalization enhances economic development (e.g., Bernhard et al. 2016). This suggests that including income could induce post-treatment bias by controlling for 
an indirect effect. Likewise, political regime type and electoral system could also be posttreatment to political party features (see, e.g., Kitschelt and Kselman 2013).

Resolving this issue and identifying the single "true" model is difficult, if not impossible. We thus rely on a strategy of testing both parsimonious models, which privileges mitigating posttreatment bias over omitted variable bias, and more extensive models, which privilege mitigating omitted variable bias. The most parsimonious models only include country- and year dummies alongside PI as regressors. Our baseline extensive specification includes four controls, which we think there is strong theoretical rationale for considering as confounders (descriptive statistics are in Table A.2). These are regime type/democracy, measured by V-Dem's Polyarchy index (Teorell et al. 2016); electoral system (PR and mixed system dummies, with plural-majoritarian as reference category) from V-Dem; income level, measured as ln GDP per capita (PPP-adjusted), from the Maddison Project (Bolt \& Zanden, 2014); and, ln population from Miller (2015).

Our results are not reliant on using these two a priori preferred specifications, and we report additional models, e.g. controlling for the lagged dependent variable (LDV) to further guard against unobserved confounders. We also highlight that we use military and public order spending as outcomes in placebo-tests to mitigate concerns that party institutionalization simply correlates with all forms of state expansion. Further, we test models controlling for features such as urbanization, trade openness, income inequality, land inequality, union density, left-wing governments, interstate wars, civil wars, political corruption, civil society strength, female political participation, and features of the state administration, and we leverage generalized sensitivity analysis to assess how great omitted variable bias from other unobserved confounders must be for our results to be spurious.

\section{Empirical Results}

We first present results from our core specifications. While we place focus on results using the composite PI and our two main measures of welfare state encompassingness and universalism, we also present results for our alternative dependent variables and for indicators tapping different, specific aspects of party institutionalization. Next, we present and discuss robustness tests. Finally, we discuss nuances and extensions, testing for how the relationship travels across different contexts. 


\section{Main results}

We start by employing Encompassingness from SPAW as dependent variable. Results are presented in the four leftmost columns of Table 1 . Model 1 is the parsimonious specification only including country- and year-fixed effects alongside PI. Drawing on 9053 observations from 134 countries, it suggests a clear, positive relationship $(t=8.8)$. The point estimate suggests that a one-unit increase on PI increases the expected number of major welfare programs at the national level by 0.59 - about one sixth of the sample-mean number of programs (3.37).

The result from Model 1 is only moderately attenuated when controlling for differences in electoral system, regime type, income and population in Model 2. While Model 2 suggests that also high levels of GDP per capita, larger populations, proportional representation, and perhaps more surprisingly (but see, Haggard \& Kaufman 2008; Knutsen \& Rasmussen forthcoming) - low levels of democracy systematically relate to welfare state encompassingness, PI only drops from 0.59 to 0.42 and remains highly significant $(t=5.9)$.

Despite the inclusion of the fixed effects alongside the theoretically motivated controls, one might worry that other (time-variant) confounders or co-integrated trends could generate a spurious link between PI and Encompassingness. Yet, different specifications that we tested and that should purge such potential confounding, including Model 3 which uses changes in Encompassingness from the previous year as dependent variable and includes a lagged dependent variable as regressor, suggest that this is not so. Even in this conservative model, PI has a t-value of 2.6.

Models 4-6 replicate Models 1-3, but using v2dlunivl as dependent variable. As anticipated by our argument, PI is a clear and strong predictor, and t-values range from 30.7 (Model 4) to 7.7 (Models 6). ${ }^{8}$ Hence, the more institutionalized political parties are, the more policies are oriented towards broad groups and the provision of public goods. In Model 4, the estimated effect of going from minimum (0) to maximum (1) on PI is a 1.31-point increase in v2dlunivl. This is only slightly lower than the sample's standard deviation on v2dlunivl (1.47) or the difference in 2010scores between (more universal) Norway or Denmark and the (less universal) United States (1.45).

\footnotetext{
8 The number of observations range from 16267 in the model excluding covariates to 7124 observations. The main reason for why the parsimonious model includes so many observations relate to V-Dem also coding the political experiences of colonies. In the extensive models, colonies are excluded due to missing data on covariates.
} 
Table 1: Party institutionalization and welfare state encompassingness, universality, generosity and size: main models

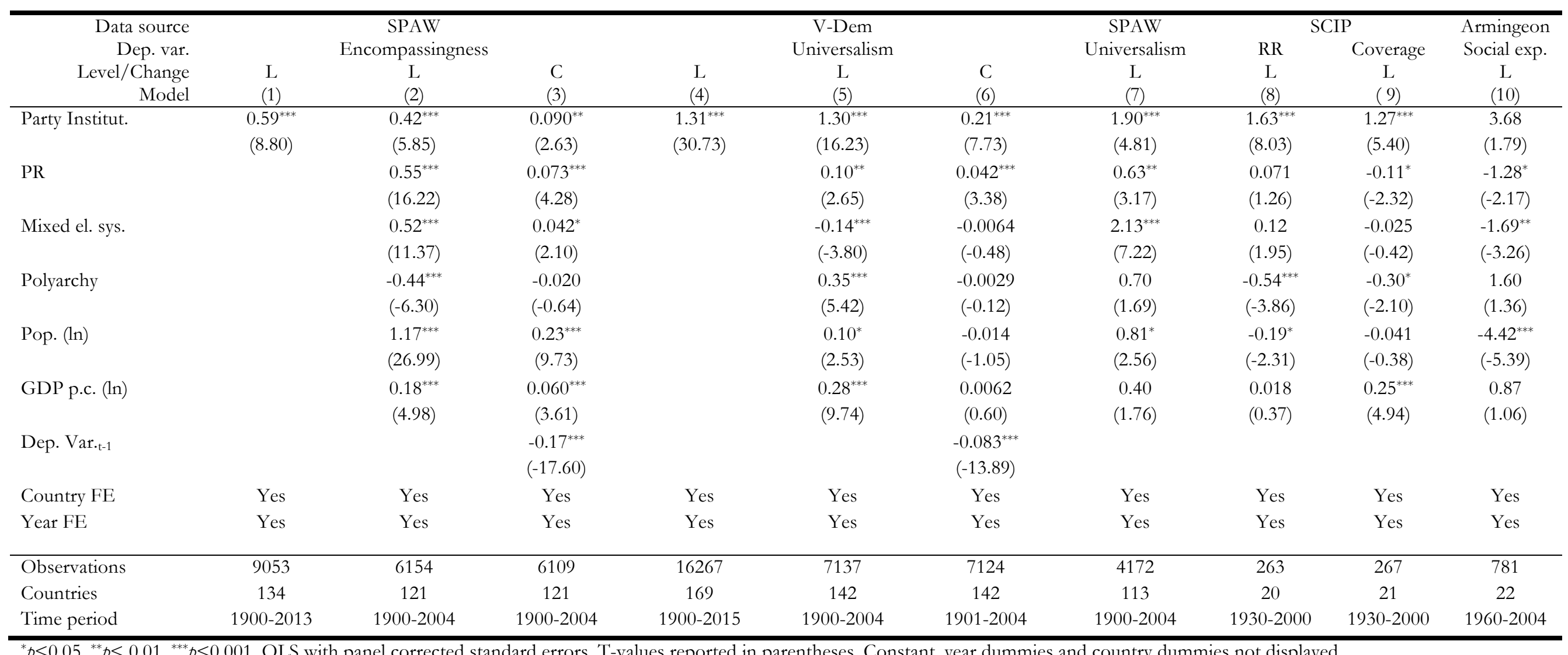


Yet, one issue cautions us against readily interpreting the results from Models 4-6 as PI having a systematic, real-world effect on universalism. This relates to the potential for coder-induced bias; results may be upward-biased since some of the same V-Dem coders are rating multiple V-Dem surveys and thus scoring countries both on the indicators included in PI and on universalism. Further, such coder biases, if present, should affect also V-Dem's electoral democracy measure (Polyarchy). Controlling for Polyarchy should therefore help purge the PI-Universalism relationship of such a bias. Encouragingly, results are very similar when including and excluding Polyarchy. Further, the PI-universalism result persisting also for universalism measures taken from other sources:

Model 7 displays the extensive specification similar to in Model 5, but using UI from SPAW. The measure counts the number of social groups covered by a social policy program in a particular area, and aggregates up over six social policy areas. While UI has its own limitations, notably that it does not capture and weight the size of the social groups, any relationship with PI should be unaffected by the type of coder bias discussed above. PI remains highly significant in Model $7(t=4.8)$, suggesting that institutionalized parties correspond with social policy programs covering more social groups, although we note that the link with PI is not as robust to changing the model specification for UI as for our other welfare measures (see, e.g., Appendix Tables A5 and A16).

The next models use measures from SCIP, namely Replacement Rates (Model 8) and Coverage (Model 9) for sickness, capturing, respectively, welfare state generosity and universalism. Only about 20 countries, mostly Western OECD democracies, with times series extending back to 1930 are included. This makes identifying any relationship with PI a very demanding exercise, even if a relationship should exist. (We remind that we control for both country- and year-fixed effects, plus the four standard covariates). Despite this, PI displays a positive and highly significant relationship with both replacement rates $(t=8.0)$ and coverage $(t=5.4)$. The small samples used in Models 8 and 9 might raise concerns that results are shaped by outliers. Further tests (removing extreme observations according to different criteria) suggest that this is not so, as also illustrated by the partial regression plots in Figure 6. 

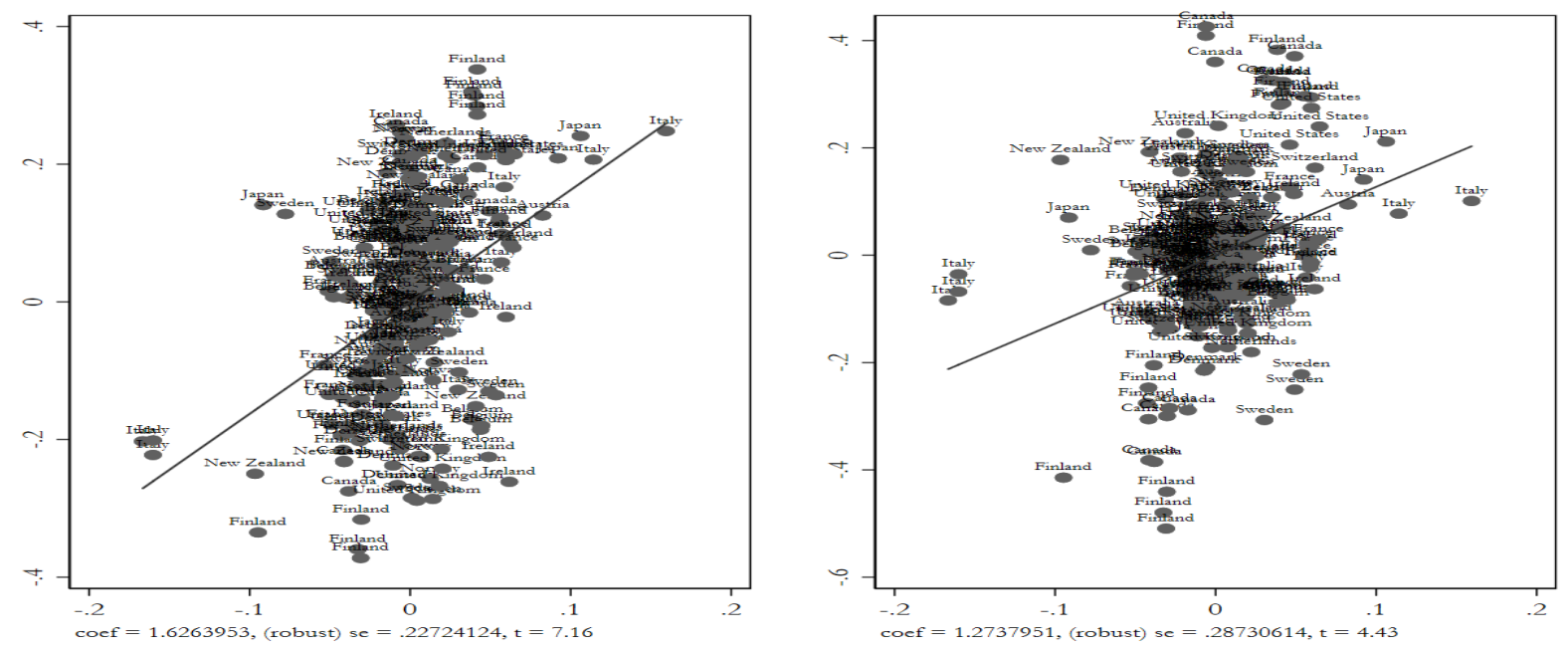

Figure 6: Partial regression plots of estimates from Models 8 (left, DV=Sickness benefits replacement rate) and 9 (right, $\mathrm{DV}=$ Sickness benefits coverage), Table 1.

In Model 10, we show results for social transfer expenditure from ILO, a rough proxy of welfare state generosity. PI is now only weakly significant $(t=1.8)$. Yet, the estimated coefficient is very large - suggesting that going from 0 to 1 on PI increases social expenditure as share of GDP by about 3.7 percentage points - and Model 10 only includes data from 22 countries and time series covering 1960-2004. ${ }^{9}$

In sum, our core specifications suggest that party institutionalization positively affects the three relevant features of a country's welfare state, namely encompassingness, universalism and generosity.

We now turn to disaggregating PI and investigating which particular aspects of party institutionalization are the most strongly related to welfare state development. Gauging results based on the individual indicators included in PI also helps inform us about which of the discussed mechanisms operate more strongly, as the indicators relate to different, theoretically relevant sub-components of party institutionalization.

\footnotetext{
9 As already noted, the confounders may be affected by PI, and thus give post-treatment when included. Hence, in Appendix A4 we remove the four confounders and re-estimate the models (we keep the two-way fixed effects). For sickness coverage and replacement rates, respectively, the estimated coefficients drop to $0.93(\mathrm{t}=7.41)$ and $0.96(\mathrm{t}=9.12)$, while for spending the coefficient increases in size and turns significant $(5.95, \mathrm{t}=4.62)$.
} 
The regressions presented in Table 2 employ the V-Dem universalism indicator (v2dlunivl) as dependent variable, but similar specifications on the alternative dependent variables are in Appendix A5. For v2dlunivl four of the five components included in PI bear a strong and consistent relationship.

Model 6 in Table 2 shows that this holds also when controlling for all five indicators simultaneously, suggesting that different mechanisms linking party institutionalization to welfare state development operate at the same time, in accordance with our comprehensive argument (and the choice of additive aggregation for PI, allowing for partial substitutability between indicators).

Table 2 Disaggregating party institutionalization and estimating effects on welfare state universalism (v2dlunivl)

\begin{tabular}{|c|c|c|c|c|c|c|}
\hline \multirow[t]{2}{*}{ Dependent variable: } & \multicolumn{6}{|c|}{ V-Dem Universalism } \\
\hline & (1) & (2) & (3) & (4) & (5) & (6) \\
\hline Party organizations & $\begin{array}{l}0.27^{* * *} \\
(17.40)\end{array}$ & & & & & $\begin{array}{l}0.21^{* * *} \\
(10.87)\end{array}$ \\
\hline Local branches & & $\begin{array}{l}0.24^{* * *} \\
(13.86)\end{array}$ & & & & $\begin{array}{c}0.071^{* * *} \\
(3.40)\end{array}$ \\
\hline Party linkages & & & $\begin{array}{l}0.33^{* * *} \\
(21.78)\end{array}$ & & & $\begin{array}{l}0.29^{* * *} \\
(18.57)\end{array}$ \\
\hline Distinct platforms & & & & $\begin{array}{c}0.065^{* * *} \\
(3.99)\end{array}$ & & $\begin{array}{l}-0.16^{* * *} \\
(-9.63)\end{array}$ \\
\hline Legislative cohesion & & & & & $\begin{array}{l}0.21^{* * *} \\
(13.87)\end{array}$ & $\begin{array}{l}0.14^{* * *} \\
(9.89)\end{array}$ \\
\hline Population (logged) & $\begin{array}{l}0.17^{* * * *} \\
(4.20)\end{array}$ & $\begin{array}{l}0.12^{* *} \\
(2.99)\end{array}$ & $\begin{array}{l}0.15^{* * *} \\
(3.70)\end{array}$ & $\begin{array}{l}0.18^{* * *} \\
(4.23)\end{array}$ & $\begin{array}{l}0.21^{\text {**** }} \\
(4.94)\end{array}$ & $\begin{array}{l}0.15^{* * *} \\
(3.89)\end{array}$ \\
\hline GDP per capita (logged) & $\begin{array}{l}0.29^{* * *} \\
(10.22)\end{array}$ & $\begin{array}{l}0.26^{* * *} \\
(8.92)\end{array}$ & $\begin{array}{l}0.22^{* * *} \\
(7.78)\end{array}$ & $\begin{array}{l}0.29^{* * *} \\
(9.94)\end{array}$ & $\begin{array}{l}0.26^{* * *} \\
(8.87)\end{array}$ & $\begin{array}{l}0.20^{* * *} \\
(7.09)\end{array}$ \\
\hline Polyarchy & $\begin{array}{l}0.38^{* * *} \\
(5.94)\end{array}$ & $\begin{array}{c}0.50^{* * *} \\
(7.70)\end{array}$ & $\begin{array}{l}0.50^{* * *} \\
(7.70)\end{array}$ & $\begin{array}{l}0.75^{* * *} \\
(10.84)\end{array}$ & $\begin{array}{l}1.05^{* * *} \\
(15.68)\end{array}$ & $\begin{array}{l}0.49^{* * *} \\
(7.63)\end{array}$ \\
\hline PR & $\begin{array}{l}0.12^{* *} \\
(3.17)\end{array}$ & $\begin{array}{l}0.12^{* *} \\
(3.17)\end{array}$ & $\begin{array}{l}0.051 \\
(1.35)\end{array}$ & $\begin{array}{l}0.11^{* *} \\
(2.81)\end{array}$ & $\begin{array}{l}0.17^{* * *} \\
(4.56)\end{array}$ & $\begin{array}{l}0.12^{* * *} \\
(3.34)\end{array}$ \\
\hline Mixed & $\begin{array}{c}-0.13^{* * *} \\
(-3.41)\end{array}$ & $\begin{array}{l}-0.13^{* * *} \\
(-3.60)\end{array}$ & $\begin{array}{l}-0.15^{* * *} \\
(-4.12)\end{array}$ & $\begin{array}{c}-0.14^{* * *} \\
(-3.62)\end{array}$ & $\begin{array}{c}-0.13^{* * *} \\
(-3.71)\end{array}$ & $\begin{array}{l}-0.12^{* * *} \\
(-3.56)\end{array}$ \\
\hline Country FE & Yes & Yes & Yes & Yes & Yes & Yes \\
\hline Year FE & Yes & Yes & Yes & Yes & Yes & Yes \\
\hline Observations & 7137 & 7137 & 7125 & 7125 & 7093 & 7093 \\
\hline Countries & 142 & 142 & 142 & 142 & 142 & 121 \\
\hline Time period & $1900-2004$ & $1900-2004$ & $1900-2004$ & $1900-2004$ & $1900-2004$ & $1900-2004$ \\
\hline
\end{tabular}

${ }^{*} p<0.05,{ }^{* *} p<0.01,{ }^{* * * *} p<0.001$. OLS with panel corrected standard errors. T-values reported in parentheses.

In Table 2, "Party linkages" displays the strongest relationship, closely followed by permanent organizations, local branches and voting cohesion. We note that presence of local branches and types of linkages were key to the bottom-up mechanisms posited in our theoretical argument, allowing 
institutionalized parties to widen their circle of constituents and elicit information from various groups. Nonetheless, also two features that are central to the proposed top-down mechanisms are relatively strong and robust. Stable national organizations are vital for bargaining and overcoming various veto players, whereas legislative party cohesion is a direct signal of parties' ability to discipline and coordinate members.

Distinct party platforms, which presumably captures a clearly expressed ideology and policybased competition between parties, has the opposite effect of what we expected in Model 6, which controls simultaneously for all five indicators. This could be an indication that mere policy-based competition between parties is not the deciding factor for introducing universal benefits. This points to the findings (discussed further below) that party institutionalization has a clear and strong effect on welfare state universalism not only in democracies, but also in autocracies. What seems to matter instead for welfare state universalism are parties' ability to ensure coordination (between salient social groups and politicians) and overcome veto players when implementing policies (our top-down mechanisms), as well as the linkages that parties form with mass constituencies and the ability to capture demands coming from broad social groups (our bottom-up mechanisms). ${ }^{10}$

\section{Robustness tests}

We tested an extensive battery of specifications to assess sensitivity. Briefly summarized, the core finding (on PI) is very robust. Most tests are presented in the Appendix, but we report and discuss a selection of important, and quite different, tests in this section, focusing on welfare state universalism. Table 3 presents these tests for the $v 2$ dlunivl.

Model 1, Table 3 replicates our extensive benchmark model (Model 6, Table 1). The first robustness test, Model 2, alters the lag specification, lagging all independent variables by five years. PI is somewhat attenuated, dropping from 1.3 to 0.8 , but remains sizeable and highly significant $(\mathrm{t}=9.9)$. In Model 3, we further extend the lag to 10 years, and PI remains robust $(t=4.6)$ although the estimated coefficient drops further to 0.3. These results suggest, first, that PI may have both fairly proximal and distal effects on welfare state development. Second, our core result is less likely to (only) reflect a

\footnotetext{
${ }^{10}$ We note that patterns are less consistent across welfare measures for the indicators-specific tests than for the combined index. For example, Party Organization and Party Linkages are robust for generosity (as measured by Replacement Rates; Table A11), whereas Distinct Platforms and Local Branches are robust for Encompassingness (Table A9).
} 
reverse causality bias, as measuring the independent variable 10 years before the dependent should help mitigate $\mathrm{X}-\mathrm{Y}$ circularity.

Despite the plausible controls in the benchmark, one might still worry that the reported relationship is inflated by omitted variable bias. We thus tested specifications with additional controls (although this typically reduces sample size and could introduce post-treatment bias). Models 4-6 are three such specifications: Model 4 includes extra socio-economic covariates that may affect universalism and correlate with PI, namely urbanization, trade openness, income inequality, and land inequality (see Appendix Table A1 for operationalization and data sources). Model 5 includes two pertinent controls for working class organization, namely union density and left-wing government. Model 6 adds controls pertaining to national-level political institutions and civil society that may determine party institutionalization and welfare policies, namely interstate war, civil war, political corruption, impartiality of the state administration, civil society strength and participation in politics, and female political participation.

These tests are important as they account for other very plausible explanations of welfare state universalism - such as working class power, civil society strength, or female political mobilization allowing particular social groups to expand the welfare state (e.g., Huber \& Stephens, 2001), or that having high-quality state institutions eases the implementation of comprehensive welfare programs (e.g., Rothstein et al., 2012). Several of these theoretically relevant controls are, indeed, highly significant in the expected direction. Yet, our main result is stable. The benchmark PI coefficient is 1.3, whereas PI ranges between 1.3 and 1.6 in Models 4-6, and t-value ranges from 7.4 to 16.3. Results remain stable when we include different combinations of controls or enter any of them separately in the benchmark.

We tested various ways of aggregating the indicators (or subsets of indicators) of PI - with one example being the extracted first component from a factor analysis (Model 7) - and our main result is robust. A specific worry is that the strong correlation between party institutionalization and universalism could come from coders considering whether parties adopt broad, national welfare programs and let this influence the coding of parties as programmatic rather than clientelist. Thus, we add the linkages indicator as a separate control in Model 8, thereby purging the PI coefficient for the influence of this indicator. While PI is attenuated, both PI and linkages are sizeable and significant at 1 percent. Our main result is also robust to dropping the linkages measure before reconstructing PI from the remaining indicators (Appendix A8). 
Further, we tested alternative estimators. Model 9, a random effects model, allows us to capture also within-country variation. PI remains comparable in size to the baseline model, although the standard error increases quite a lot. Nonetheless, PI remains significant at 1 percent. In Model 10 we employ the ordinalized version of v2dlunivl and re-estimate our benchmark specification using ordinal logistic regression. PI remains robust.

Table 3: Robustness tests on welfare state universalism (v2dlunivl)

\begin{tabular}{|c|c|c|c|c|c|c|c|c|c|c|}
\hline \multirow[t]{2}{*}{ Estimation } & $\begin{array}{l}(1) \\
\text { OLS }\end{array}$ & $\begin{array}{c}(2) \\
\text { OLS }\end{array}$ & $\begin{array}{c}(3) \\
\text { OLS }\end{array}$ & $\begin{array}{c}(4) \\
\text { OLS }\end{array}$ & $\begin{array}{l}\text { (5) } \\
\text { OLS }\end{array}$ & $\begin{array}{c}(6) \\
\text { OLS }\end{array}$ & $\begin{array}{c}(7) \\
\text { OLS }\end{array}$ & $\begin{array}{c}(8) \\
\text { OLS }\end{array}$ & $\begin{array}{l}\text { (9) } \\
\text { RE }\end{array}$ & $\begin{array}{c}(10) \\
\text { RE } \\
\text { Ologit }\end{array}$ \\
\hline & Baseline & $\begin{array}{c}5 \text { year } \\
\text { lag }\end{array}$ & $\begin{array}{c}10 \text { year } \\
\text { lag }\end{array}$ & $\begin{array}{c}\text { Socio- } \\
\text { econ. } \\
\text { controls }\end{array}$ & $\begin{array}{c}\text { Work. } \\
\text { class } \\
\text { controls }\end{array}$ & $\begin{array}{l}\text { Instit. and } \\
\text { civil society } \\
\text { controls }\end{array}$ & $\begin{array}{c}\text { First } \\
\text { component } \\
\text { PI } \\
\end{array}$ & $\begin{array}{l}\text { Control } \\
\text { linkages } \\
\end{array}$ & $\begin{array}{c}\text { Random } \\
\text { effects } \\
\text { model }\end{array}$ & $\begin{array}{l}\text { Ordinal } \\
\text { logistic }\end{array}$ \\
\hline Party Instit. & $\begin{array}{l}1.30^{* * *} \\
(16.23)\end{array}$ & $\begin{array}{c}0.75^{* * *} \\
(9.89)\end{array}$ & $\begin{array}{l}0.34^{* * *} \\
(4.64)\end{array}$ & $\begin{array}{l}1.26^{* * *} \\
(11.32)\end{array}$ & $\begin{array}{l}1.64^{* * *} \\
(7.44)\end{array}$ & $\begin{array}{l}1.26^{* * *} \\
(16.33)\end{array}$ & $\begin{array}{l}0.33^{* * *} \\
(20.85)\end{array}$ & $\begin{array}{l}0.75^{* * *} \\
(8.91)\end{array}$ & $\begin{array}{l}1.29^{* *} \\
(2.65)\end{array}$ & $\begin{array}{l}3.47^{*} \\
(2.25)\end{array}$ \\
\hline Polyarchy & $\begin{array}{l}0.35^{* * *} \\
(5.42)\end{array}$ & $\begin{array}{l}0.70^{* * *} \\
(10.67)\end{array}$ & $\begin{array}{l}0.85^{* * *} \\
(12.56)\end{array}$ & $\begin{array}{l}0.59^{* * *} \\
(8.13)\end{array}$ & $\begin{array}{l}1.65^{* * *} \\
(11.11)\end{array}$ & $\begin{array}{c}-0.37^{* * * *} \\
(-3.80)\end{array}$ & $\begin{array}{l}0.23^{* * *} \\
(3.53)\end{array}$ & $\begin{array}{l}0.28^{* * *} \\
(4.35)\end{array}$ & $\begin{array}{c}0.34 \\
(0.99)\end{array}$ & $\begin{array}{c}1.89 \\
(1.46)\end{array}$ \\
\hline Pop. (ln) & $\begin{array}{l}0.10^{*} \\
(2.53)\end{array}$ & $\begin{array}{l}0.14^{* *} \\
(3.09)\end{array}$ & $\begin{array}{l}0.20^{* * *} \\
(4.24)\end{array}$ & $\begin{array}{l}0.62^{* * *} \\
(9.51)\end{array}$ & $\begin{array}{l}-0.61^{* * *} \\
(-6.50)\end{array}$ & $\begin{array}{l}0.28^{* * *} \\
(6.82)\end{array}$ & $\begin{array}{l}0.14^{* * *} \\
(3.51)\end{array}$ & $\begin{array}{l}0.11^{* *} \\
(2.75)\end{array}$ & $\begin{array}{l}0.014 \\
(0.10)\end{array}$ & $\begin{array}{c}-0.25 \\
(-0.43)\end{array}$ \\
\hline GDP pc (ln) & $\begin{array}{l}0.28^{* * *} \\
(9.74)\end{array}$ & $\begin{array}{l}0.24^{* * *} \\
(7.90)\end{array}$ & $\begin{array}{l}0.24^{* * *} \\
(7.86)\end{array}$ & $\begin{array}{l}0.42^{* * * *} \\
(12.38)\end{array}$ & $\begin{array}{c}0.23^{* * *} \\
(3.31)\end{array}$ & $\begin{array}{l}0.25^{* * *} \\
(7.99)\end{array}$ & $\begin{array}{l}0.22^{* * *} \\
(7.66)\end{array}$ & $\begin{array}{l}0.23^{* * *} \\
(7.93)\end{array}$ & $\begin{array}{l}0.25^{*} \\
(1.98)\end{array}$ & $\begin{array}{l}1.06^{* *} \\
(2.61)\end{array}$ \\
\hline PR & $\begin{array}{l}0.10^{* *} \\
(2.65)\end{array}$ & $\begin{array}{l}0.10^{*} \\
(2.50)\end{array}$ & $\begin{array}{l}0.080 \\
(1.88)\end{array}$ & $\begin{array}{l}-0.21^{* * *} \\
(-4.24)\end{array}$ & $\begin{array}{l}0.58^{* * *} \\
(9.53)\end{array}$ & $\begin{array}{l}0.13^{* * *} \\
(3.61)\end{array}$ & $\begin{array}{l}0.094^{*} \\
(2.55)\end{array}$ & $\begin{array}{l}0.044 \\
(1.17)\end{array}$ & $\begin{array}{c}0.10 \\
(0.61)\end{array}$ & $\begin{array}{c}0.40 \\
(0.74)\end{array}$ \\
\hline Mixed & $\begin{array}{c}-0.14^{* * *} \\
(-3.80)\end{array}$ & $\begin{array}{c}-0.14^{* * *} \\
(-3.61)\end{array}$ & $\begin{array}{l}-0.17^{* * * *} \\
(-4.21)\end{array}$ & $\begin{array}{l}-0.26^{* * *} \\
(-5.95)\end{array}$ & $\begin{array}{l}0.48^{* * *} \\
(5.24)\end{array}$ & $\begin{array}{l}-0.068 \\
(-1.83)\end{array}$ & $\begin{array}{l}-0.16^{* * *} \\
(-4.26)\end{array}$ & $\begin{array}{c}-0.16^{* * *} \\
(-4.33)\end{array}$ & $\begin{array}{l}-0.14 \\
(-0.80)\end{array}$ & $\begin{array}{c}-0.51 \\
(-0.88)\end{array}$ \\
\hline Urbaniz. & & & & $\begin{array}{c}1.1 \mathrm{e}-10 \\
(0.19)\end{array}$ & & & & & & \\
\hline Openness & & & & $\begin{array}{c}0.0017 \\
(0.92)\end{array}$ & & & & & & \\
\hline Income ineq. & & & & $\begin{array}{c}-0.0044^{* *} \\
(-3.04)\end{array}$ & & & & & & \\
\hline Fam. farms & & & & $\begin{array}{c}0.0065^{* * *} \\
(5.48)\end{array}$ & & & & & & \\
\hline Union dens. & & & & & $\begin{array}{c}0.0077^{* * *} \\
(7.16)\end{array}$ & & & & & \\
\hline Left & & & & & $\begin{array}{c}0.15^{* * *} \\
(4.83)\end{array}$ & & & & & \\
\hline Inter-st. war & & & & & & $\begin{array}{l}-0.052 \\
(-1.47)\end{array}$ & & & & \\
\hline Civil war & & & & & & $\begin{array}{c}-0.19^{* * *} \\
(-5.65)\end{array}$ & & & & \\
\hline Corruption & & & & & & $\begin{array}{l}-1.22^{* * *} \\
(-12.03)\end{array}$ & & & & \\
\hline Imp. Admin. & & & & & & $\begin{array}{c}0.13^{* * *} \\
(8.89)\end{array}$ & & & & \\
\hline Civil society & & & & & & $\begin{array}{l}-0.50 \\
(-0.57)\end{array}$ & & & & \\
\hline Female parti. & & & & & & $\begin{array}{l}1.87^{* * *} \\
(24.97)\end{array}$ & & & & \\
\hline Party link. & & & & & & & & $\begin{array}{l}0.27^{* * *} \\
(16.26)\end{array}$ & & \\
\hline Country FE & Yes & Yes & Yes & Yes & Yes & Yes & Yes & Yes & No & No \\
\hline Year FE & Yes & Yes & Yes & Yes & Yes & Yes & Yes & Yes & Yes & Yes \\
\hline Observations & 7137 & 6975 & 6732 & 4208 & 1635 & 6116 & 7093 & 7125 & 7137 & 7137 \\
\hline Countries & 142 & 142 & 142 & 129 & 31 & 130 & 142 & 142 & 142 & 142 \\
\hline Time Period & $\begin{array}{l}1900- \\
2004\end{array}$ & $\begin{array}{l}1905- \\
2004\end{array}$ & $\begin{array}{l}1910- \\
2004\end{array}$ & $\begin{array}{l}1935- \\
2004\end{array}$ & $\begin{array}{l}1900- \\
2004\end{array}$ & $\begin{array}{l}1900- \\
2004\end{array}$ & $\begin{array}{l}1900- \\
2004\end{array}$ & $\begin{array}{l}1900- \\
2004\end{array}$ & $\begin{array}{l}1900- \\
2004\end{array}$ & $\begin{array}{l}1900- \\
2004\end{array}$ \\
\hline
\end{tabular}


We undertook two placebo-tests, using military spending and public-order spending as dependent variables (Appendix A9). We argued that party institutionalization is key to welfare state development because it incentivizes and enables parties to carry out national, universal legislative proposals even when particularistic elite interests oppose these initiatives. We surmise that military and public-order spending do not face similar hostile vested (elite) interests, and we otherwise fail to see how our argument should pertain clearly to such spending. Consequently, we should not observe a clear relationship between PI and these measures. Instead, a significant relationship might indicate that PI correlates with all forms of state expansion, and that the relationship of interest is driven by some unmeasured confounder (although we remind that we control for state capacity measures above). Nonetheless, while PI is positively correlated with military spending, it is far from statistically significant ( $t$-value 0.39$)$. For public order spending the relationship is negative and insignificant $(t$-value -0.63$)$.

To further assess the likelihood that omitted confounders are driving our results, we test how serious such bias would have to be to reduce the PI coefficient by half, using generalized sensitivity analysis (GSA). This analysis suggests that any omitted factor would have to correlate much higher with our welfare measures and PI than any of the theoretically plausible controls that we have identified and included in our regressions. This increases our confidence that omitted variable bias is not driving the observed correlation.

\section{Assessing heterogeneity}

We turn now to testing whether our estimates mask heterogeneous effects across contexts. We investigate this by splitting our samples on theoretically interesting factors, which provides a simple and transparent way of investigating effect heterogeneity (Appendix A10 reports interaction models). In general, we find systematic links between party institutionalization and the different welfare state features in various contexts. Again, we mainly focus on results for v2dlunivl, and display other dependent variables in Appendix A7.

First, we investigate whether the effect of party institutionalization is restricted to democratic contexts. We noted that the bottom-up mechanisms of our argument might not work as strongly in autocracies as in democracies, although the top-down mechanisms suggest that institutionalized parties should enhance, e.g., universalism in both democracies and autocracies. Splitting the sample according to the dichotomous Boix, Miller \& Rosato (2013) democracy measure (BMR), we find that PI is about 
three times larger in democracies (Model 2, Table 4) than in autocracies (Model 1). Nonetheless, PI is substantially large and highly significant ( $t=7.8$ in Model 1) also in the sub-sample for autocracies. This difference across regimes is persistent, but typically smaller, in other specifications that we tested; Figure 7 presents point estimates from an interaction specification (resembling Models 1 and 2, but adding $\left.\mathrm{PI}{ }^{*} \mathrm{BMR}\right)$ run on the full sample. PI is a significant predictor in both regime contexts, but the estimated effect is about twice as large in BMR democracies. Hence, institutionalized parties foster more universal social policies in both autocracies and in democracies, though they seem even more important in the latter context. ${ }^{11}$

Table 4 Split sample tests on party institutionalization and welfare state universalism (v2dlunivl)

\begin{tabular}{|c|c|c|c|c|c|c|}
\hline Sample: & $\begin{array}{c}\text { (1) } \\
\text { Autocratic }\end{array}$ & $\begin{array}{c}(2) \\
\text { Democratic }\end{array}$ & $\begin{array}{c}\text { (3) } \\
\text { Western } \\
\text { countries } \\
\end{array}$ & $\begin{array}{c}\text { (4) } \\
\begin{array}{c}\text { Non-western } \\
\text { countries }\end{array} \\
\end{array}$ & $\begin{array}{c}\text { (5) } \\
\text { Low rural } \\
\text { inequality }\end{array}$ & $\begin{array}{c}\text { (6) } \\
\text { High rural } \\
\text { inequality } \\
\end{array}$ \\
\hline Party Institut. & $\begin{array}{l}0.73^{* * *} \\
(7.77)\end{array}$ & $\begin{array}{l}2.42^{* * *} \\
(16.19)\end{array}$ & $\begin{array}{l}2.30^{* * *} \\
(13.13)\end{array}$ & $\begin{array}{l}0.98^{* * *} \\
(11.94)\end{array}$ & $\begin{array}{l}1.21^{* * *} \\
(13.25)\end{array}$ & $\begin{array}{l}0.94^{* * *} \\
(7.17)\end{array}$ \\
\hline Population (ln) & $\begin{array}{l}-0.26^{* *} \\
(-2.97)\end{array}$ & $\begin{array}{l}-0.012 \\
(-0.27)\end{array}$ & $\begin{array}{c}-0.35^{* * *} \\
(-3.96)\end{array}$ & $\begin{array}{l}0.48^{* * *} \\
(7.90)\end{array}$ & $\begin{array}{l}0.46^{* * *} \\
(9.04)\end{array}$ & $\begin{array}{c}0.17 \\
(1.54)\end{array}$ \\
\hline GDP p.c. (ln) & $\begin{array}{l}0.19^{* * *} \\
(5.05)\end{array}$ & $\begin{array}{l}0.54^{* * *} \\
(15.77)\end{array}$ & $\begin{array}{l}0.60^{* * *} \\
(7.45)\end{array}$ & $\begin{array}{l}0.23^{* * *} \\
(7.57)\end{array}$ & $\begin{array}{l}0.47^{* * *} \\
(15.85)\end{array}$ & $\begin{array}{l}0.23^{* *} \\
(2.99)\end{array}$ \\
\hline PR & $\begin{array}{l}-0.030 \\
(-0.65)\end{array}$ & $\begin{array}{l}0.078 \\
(1.75)\end{array}$ & $\begin{array}{l}0.52^{* * *} \\
(9.44)\end{array}$ & $\begin{array}{l}-0.10^{*} \\
(-2.45)\end{array}$ & $\begin{array}{l}0.038 \\
(1.01)\end{array}$ & $\begin{array}{l}0.15^{* *} \\
(2.58)\end{array}$ \\
\hline Mixed & $\begin{array}{c}-0.22^{* * *} \\
(-4.62)\end{array}$ & $\begin{array}{l}0.12^{*} \\
(1.98)\end{array}$ & $\begin{array}{l}0.48^{* * *} \\
(4.83)\end{array}$ & $\begin{array}{c}-0.22^{* * *} \\
(-5.40)\end{array}$ & $\begin{array}{c}-0.20^{* * *} \\
(-4.39)\end{array}$ & $\begin{array}{c}0.13 \\
(1.96)\end{array}$ \\
\hline Polyarchy & & & $\begin{array}{l}1.00^{* * *} \\
(8.46)\end{array}$ & $\begin{array}{l}-0.069 \\
(-0.97)\end{array}$ & $\begin{array}{l}-0.026 \\
(-0.37)\end{array}$ & $\begin{array}{l}0.65^{* * *} \\
(5.56)\end{array}$ \\
\hline Country FE & Yes & Yes & Yes & Yes & Yes & Yes \\
\hline Year FE & Yes & Yes & Yes & Yes & Yes & Yes \\
\hline Observations & 3981 & 3137 & 1718 & 5419 & 4167 & 2885 \\
\hline Countries & 115 & 98 & 20 & 122 & 124 & 93 \\
\hline Time period & 1900-2004 & 1900-2004 & 1900-2004 & 1900-2004 & 1900-2004 & 1900-2004 \\
\hline
\end{tabular}

\footnotetext{
11 For Encompassingness, the estimated split-sample coefficient is positive but close to zero for autocracies, but substantially large and significant for democracies. For additional split-sample and interaction tests, see Appendices A7 and A10.
} 


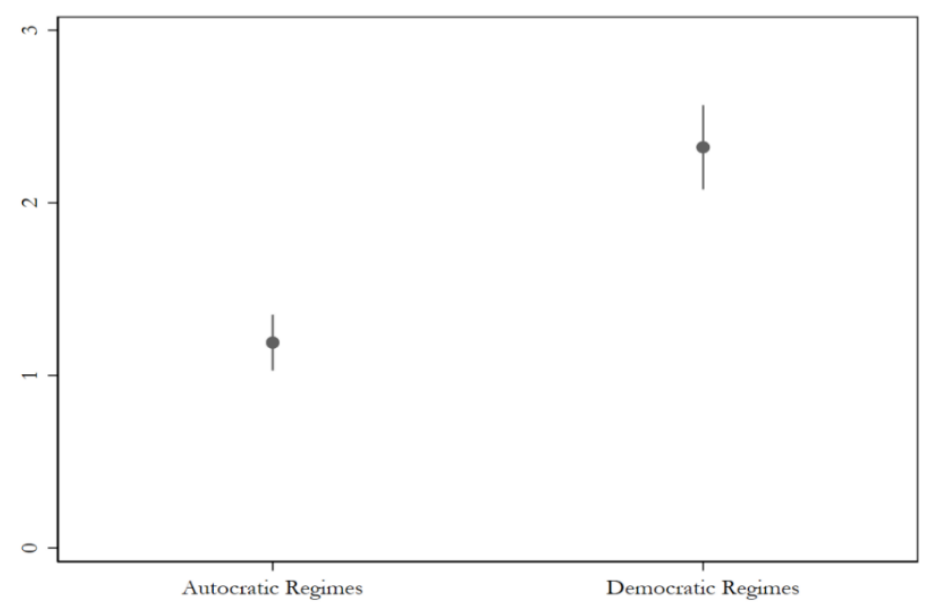

Figure 7. Estimated effect on v2dlunivl of increasing PI from 0 to 1 in autocracies and democracies, with 95 confidence intervals. The specification resembles Models 1 and 2, Table 4 , but is run on full sample and includes interaction term.

Second, we wanted to test whether our results are mainly driven by the experiences of Western countries. If so, the support for our (general) argument would be weakened, or at the very least this would suggest some (un-theorized) historical or cultural pre-requisites for our mechanisms to work. While we do find that the estimated PI is larger in Western (Model 3; 2.3) than other (Model 4; 1.0) countries, PI is substantial in size and highly significant in both samples. Appendix A10 for example contains analysis removing specific regions from the sample in seriatim, and the relationship is surprisingly robust across geographical contexts.

Third, we checked whether the effect is strongly contingent on the socio-economic context. One might, for example, hypothesize that strong, mass-based parties help ensure the formulation and effective implementation of universal welfare programs only where there is low economic inequality, and thus smaller redistributive burdens on elites (see Boix 2003). Alternatively, institutionalized parties could display a stronger relationship with universalism in high-inequality settings, as institutionalized parties would be a requisite to overcome powerful elite groups, such as rural landlords, in these contexts. Yet, when using Vanhanen's share of family farms as proxy for land inequality, and splitting the sample at the median, PI is systematically linked to universalism in both low- and high-inequality settings - the coefficient is only moderately higher in low-inequality settings. Results are basically similar if we split the sample using Gini coefficients on income inequality (see Table A33). Neither is the effect of party institutionalization restricted to developing or developed countries. When splitting 
the sample by median GDP per capita, PI relates quite similarly (and significantly) to $v 2$ dlunivl in both contexts. Additional tests show fairly consistent relationships also across countries that are less or more corrupt or that have less or more impartial public administration, suggesting that having strong state institutional capacity is not a pre-requisite for institutionalized parties to influence welfare state development (c.f. Shefter, 1977).

Finally, we investigated whether the relationship is non-linear by employing a Kernel Regularized Least Squares (KRLS) method, computing marginal effects for each observation (Hainmueller \& Hazlett, 2014). Notably, the marginal effects are consistently positive and highly significant for all our dependent variables (except for social transfer spending/GDP, the only nonsignificant predictor from Table 1), and suggest close to linear relationships. Thus, increased PI seems to go together with more encompassing, universal and generous welfare states, no matter if we start out at relatively low or high levels of party institutionalization

\section{Conclusion}

We have argued that highly institutionalized parties have both the incentives and the capacity to enact more universal and generous social policy programs covering against various risks. We identify to type of mechanisms that contribute to this relationship, namely "bottom-up" and "top-down" mechanisms. The former refers to the ability of parties to widen their circle of constituents and elicit information about their demands, whereas the latter refers to the ability of parties to overcome veto players inside and outside their organization and effectively implement policies. Both types of mechanisms are theorized to pull in the same direction, implying that highly institutionalized parties should make for more encompassing, universal, and generous welfare states. These expectations find very robust support in our empirical analysis, even when accounting for country-specific and time-specific factors or measured differences in institutional features such as regime type, electoral system, civil society organization, or state capacity. Our extensive samples, going well beyond the "typical" set of developed post-war OECD democracies used in many extant studies of political parties or welfare states, allow us to assess whether or not our (purportedly general) theoretical argument finds support in various spatial, temporal, socio-economic and political regime contexts - as it generally turns out to do.

Our argument and empirical results speak to hitherto distinct literatures: First, we contribute to the welfare state literature. Previous explanations of the origins of the universal welfare state have often 
focused on specific actors or the power-balance between actors, typically highlighting working class organization or social democratic parties (e.g., Huber \& Stephens 2001), democratization and bureaucratization (Orloff \& Skocpol, 1984), or a combination of impartial and effective state institutions and working class mobilization (e.g., Rothstein et al., 2012). Our analysis does find that working-class organization and state structures matter for welfare development, but neither factor cancels out the result that party institutionalization strongly relates to welfare development.

Second, we contribute to work on political parties and their effects. A vast literature has detailed how features of parties in democratic systems, and party institutionalization in particular, shape various outcomes, including democratic stability and public goods provision (e.g., Hicken et al., 2015). Likewise, a rapidly growing literature on parties in autocracies has detailed how institutionalized parties - and regime parties in particular - affect different outcomes such as regime stability, prospects for democratization, and investment (e.g., Gehlbach \& Keefer, 2011; Magaloni, 2006; Svolik, 2012; Wright, 2008). We add to (and bridge) these literatures by showing how party institutionalization matters also for different welfare state features, and by theorizing and showing that the effects of party institutionalization manifest themselves in both democratic and autocratic settings. 


\section{References}

Acemoglu, D., \& Robinson, J.A. (2006). Economic origins of dictatorship and democracy. Cambridge:

Cambridge University Press.

Ansell, B.W., \& Samuels, D.J. (2014). Inequality and democratization: An elite-competition approach. New York: Cambridge University Press.

Ansolabehere, S., Snyder, J.M., \& Stewart, C. (2001). Candidate positioning in US House elections. American Journal of Political Science, 45(1):136-159.

Armingeon, K., Careja, R., Weisstanner, D., Engler, S., Potolidis, P., \& Gerber, M. (2017). Comparative Political Dataset III (35 OECD Countries).

Baldwin, P. (1990). The politics of social solidarity: Class bases of the European welfare state 1875-1975.

Cambridge: Cambridge University Press.

Bartolini, S. (2000). The political mobilization of the European left, 1860-1980: The class cleavage. Cambridge: Cambridge University Press.

Bernhard, M., Bizzarro, F., Gerring, J., Hicken, A., Knutsen, C.H., Skaaning, S.E., Coppedge, M., and Lindberg, S.I. (2016). Party Strength and Economic Growth. Gothenburg: V-Dem Working Paper 10. Link: http://hdl.handle.net/2077/40540

Bizzarro, F, Hicken, A, and Self, D. (2017). The V-Dem Party Institutionalization Index: A New Global Indicator (1900-2015). Gothenburg: V-Dem Working Paper 48. Link: https://papers.ssrn.com/sol3/papers.cfm?abstract_id=2968265

Boix, C. (2003). Democracy and redistribution. Cambridge, UK; New York: Cambridge University Press.

Boix, C., Miller, M., \& Rosato, S. (2013). A Complete Data Set of Political Regimes, 1800-2007. Comparative Political Studies, 46(12):1523-1554.

Boix, C., \& Svolik, M. (2013). The Foundations of Limited Authoritarian Government: Institutions, Commitment, and Power-Sharing in Dictatorships. Journal of Politics, 75(2):300-316.

Bolt, J., \& Zanden, J.L. (2014). The Maddison Project: Collaborative research on historical national accounts. The Economic History Review, 67(3):627-651.

Brancati, D. (2014). Democratic Authoritarianism: Origins and Effects. Annual Review of Political Science, 17:313-326.

Brownlee, J. (2009). Portents of Pluralism: How Hybrid Regimes Affect Democratic Transitions. American Journal of Political Science, 53(3):515-532.

Bueno de Mesquita, B., Smith A., Siverson, R.M., \& Morrow, J.D. (2003). The Logic of Political Survival. Cambridge, MA.: MIT Press. 
Carreras, M. (2012). Party systems in Latin America after the Third Wave: A critical re-assessment. Journal of Politics in Latin America, 4(1):135-153.

Coppedge, M., Gerring, J., Lindberg, S.I., Skaaning, S.E., Teorell, J., Altman, D., Bernhard, M., Fish, M.S., Glynn, A., Hicken, A., Knutsen, C.H., Marquardt, K., McMann, K., Miri, F., Paxton, P., Pemstein, D., Staton, J., Tzelgov, E., Wang, Y. and Zimmerman B. (2016a). "V-Dem Country-Year Dataset v6." Varieties of Democracy Project.

Coppedge, M., Gerring, J., Lindberg, S.I., Skaaning, S.E., Teorell, J., Altman, D., Andersson, F., Bernhard, M., Fish, M.S., Glynn, A., Hicken, A., Knutsen, C.H. , McMann, K., Mechkova, V., Miri, F., Paxton, P., Pemstein, D. Sigman, R., Staton, J., and Zimmerman B. (2016b). "VDem Codebook v6." Varieties of Democracy Project.

Croissant, A., \& Volkel, P. (2012). Party system types and party system institutionalization: Comparing new democracies in East and Southeast Asia. Party Politics, 18(2):235-265.

Ehrlich, S.D. (2007). Access to protection: Domestic institutions and trade policy in democracies. International Organization, 61(3):571-605.

Elkins, Z. (2010). Diffusion and the Constitutionalization of Europe. Comparative Political Studies, 43(89):969-999.

Esping-Andersen, G. (1999). Social Foundations of Postindustrial Economies. Oxford: Oxford University Press.

Fukuyama, F. (2015). Political Order and Political Decay. New York: Farrar, Straus and Giroux.

Geddes, B. (1999). What do we know about democratization after twenty years? Annual Review of Political Science, 2:115-144.

Gehlbach, S., \& Keefer, P. (2011). Investment without democracy: Ruling-party institutionalization and credible commitment in autocracies. Journal of Comparative Economics, 39(2):123-139.

Gerring, J., \& Thacker, S.C. (2004). Political institutions and corruption: The role of unitarism and parliamentarism. British Journal of Political Science, 34:295-330.

Goertz, G. (2006). Social science concepts : a user's guide. New Jersey: Princeton University Press.

Haggard, S., \& Kaufman, R.R. (2008). Development, democracy, and welfare states : Latin America, East Asia, and Eastern Europe. Princeton: Princeton University Press.

Hainmueller, J., \& Hazlett, C. (2014). Kernel regularized least squares: Reducing misspecification bias with a flexible and interpretable machine learning approach. Political Analysis, 22(2):143-168.

Hicken, A., Kollman, K., \& Simmons, J.W. (2016). Party System Nationalization and the Provision of Public Health Services. Political Science Research and Methods, 4(3):573-594. 
Hicken, A., Kuhonta, E.M., \& Weiss, M. L. (2015). Party system institutionalization in Asia : democracies, autocracies, and the shadows of the past. New York: Cambridge University Press.

Hicken, A., \& Simmons, J.W. (2008). The personal vote and the efficacy of education spending. American Journal of Political Science, 52(1):109-124.

Huber, E., \& Stephens, J.D. (2001). Development and crisis of the welfare state : parties and policies in global markets. Chicago: The University of Chicago Press.

Huntington, S.P. (1968). Political order in changing societies. New Haven: Yale University Press.

Iversen, T. (2005). Capitalism, democracy, and welfare. Cambridge: Cambridge University Press.

Jurado, I. (2014). Party system nationalisation and social spending. European Journal of Political Research, 53(2):288-307.

Jurado, I., \& Leon, S. (Forthcoming). Geography Matters: The Conditional Effect of Electoral Systems on Social Spending. British Journal of Political Science, Firstview:1-23.

Keefer, P. (2007). Clientelism, credibility, and the policy choices of young democracies. American Journal of Political Science, 51(4):804-821.

Kim, W., \& Gandhi, J. (2010). Coopting Workers under Dictatorship. Journal of Politics, 72(3):646-658.

Kitschelt, H. (2000). Linkages between citizens and politicians in democratic polities. Comparative Political Studies, 33(6-7):845-879.

Kitschelt, H., \& Kselman, D.M. (2013). Economic Development, Democratic Experience, and Political Parties' Linkage Strategies. Comparative Political Studies, 46(11):1453-1484.

Knutsen, C.H., \& Rasmussen, M.B. (Forthcoming). The Autocratic Welfare State Resource Distribution, Credible Commitments and Political Survival. Comparative Political Studies. FirstView. Link: http://journals.sagepub.com/doi/abs/10.1177/0010414017710265

Korpi, W., \& Palme, J. (2007). The social citizenship indicator program (SCIP). Swedish Institute for Social Research, Stockholm University.

Levitsky, S. (1998). Crisis, party adaptation and regime stability in Argentina - The case of Peronism, 1989-1995. Party Politics, 4(4):445-470.

Levitsky, S., \& Way, L. (2010). Competitive authoritarianism : bybrid regimes after the Cold War. New York: Cambridge University Press.

Lindert, P.H. (2004). Growing public: Social spending and economic growth since the eighteenth century. Cambridge: Cambridge University Press.

Magaloni, B. (2006). Voting for autocracy : hegemonic party survival and its demise in Mexico. Cambridge: Cambridge University Press. 
Mainwaring, S., \& Scully, T.R. (1995). Building democratic institutions : party systems in Latin America. Stanford: Stanford University Press.

Mares, I. (2005). Social protection around the world - External insecurity, state capacity, and domestic political cleavages. Comparative Political Studies, 38(6):623-651.

Mares, I., \& Carnes, M.E. (2009). Social Policy in Developing Countries. Annual Review of Political Science, 12:93-113.

Martin, C.J., \& Swank, D. (2008). The political origins of coordinated capitalism: Business organizations, party systems, and state structure in the age of innocence. American Political Science Review, 102(2):181-198.

Miller, M.K. (2015). Electoral Authoritarianism and Human Development. Comparative Political Studies, 48(12):1526-1562.

Moene, K.O., \& Wallerstein, M. (2001). Inequality, social insurance, and redistribution. American Political Science Review, 95(4):859-874.

Orloff, A.S., \& Skocpol, T. (1984). Why not equal protection? Explaining the politics of public social spending in Britain, 1900-1911, and the United States, 1880s-1920. American Sociological Review, 49(6):726-750.

Pemstein, D., K. Marquardt, E. Tzelgov, Y. Wang, \& Miri, F. (2017). The V-Dem Measurement Model: Latent Variable Analysis for Cross-National and Cross-Temporal Expert-Coded Data. University of Gothenburg:V-Dem Working Paper 21. Link: https://www.vdem.net/media/filer_public/9a/18/9a188a8b-1073-4bbb-9831-20d200a358c3/vdem_working_paper_2015_1.pdf

Persson, T., \& Tabellini, G. (2004). Constitutions and Economic Policy. Journal of Economic Perspectives, 18(1):75-98.

Przeworski, A. (2010). Democracy and the limits of self-government. Cambridge: Cambridge University Press.

Randall, V., \& Svåsand, L. (2002). Political parties and democratic consolidation in Africa. Democratization, 9(3):30-52.

Rasmussen, M.B. (2016). How organized labor shaped the origin and structure of the regulatory revolution 18702000. PhD dissertation. Aarhus: Politica.

Rogowski, R. (1987). Trade and the Variety of Democratic Institutions. International Organization, 41(2), 203-223.

Rothstein, B., Samanni, M., \& Teorell, J. (2012). Explaining the welfare state: power resources vs. the Quality of Government. European Political Science Review, 4(1):1-28.

Schattschneider, E.E. (1942). Party government. New York: Farrar and Rinehart. 
Schumacher, G. (2012). 'Marx'or the market? Intra-party power and social democratic welfare state retrenchment. West European Politics, 35(5):1024-1043.

Schumacher, G., De Vries, C.E., \& Vis, B. (2013). Why do parties change position? Party organization and environmental incentives. Journal of Politics, 75(2):464-477.

Scruggs, L. (2006). The generosity of social insurance, 1971-2002. Oxford Review of Economic Policy, 22(3):349-364.

Scruggs, L., \& Allan, J.P. (2008). Social stratification and welfare regimes for the twenty-first century: Revisiting the three worlds of welfare capitalism. World Politics, 60(4):642-664.

Shefter, M. (1977). Party and Patronage: Germany, England, and Italy. Politics \& Society, 7(4):403-451.

Svolik, M. (2008). Authoritarian reversals and democratic consolidation. American Political Science Review, 102(2):153-168.

Svolik, M. (2012). The Politics of Authoritarian Rule. Cambridge: Cambridge University Press.

Tsebelis, G. (2002). Veto Players : How Political Institutions Work. New Jersey: University Presses of California, Columbia and Princeton.

Wintrobe, R. (1998). The political economy of dictatorship. Cambridge: Cambridge University Press.

Wright, J. (2008). Do authoritarian institutions constrain? How legislatures affect economic growth and investment. American Journal of Political Science, 52(2):322-343. 


\section{Appendices}

\section{Overview}

The appendices in this document contain the following material: Appendix A1 includes descriptions of the variables used for the analysis, and lists the sources from which they are drawn. A2 displays descriptive statistics for the observations included in different core models in Table 1 of the paper. A3 lists the country-year observations included in Model, Table 1.

The subsequent appendices contain additional robustness tests and extensions that are not reported in tables or figures in the paper. A4 displays our core specifications on alternative dependent variables, as well as specifications using different control variable sets. A5 replicates the indicator-specific tests from Table 2, disaggregating the components of the Party Institutionalization index, for other dependent variables than the V-Dem universalism indicator. A6 replicates the core robustness tests from Table 3 for the alternative dependent variables, and shows additional tests adding controls to our benchmark model. A7 replicates the split-sample tests from Table 4 for the other dependent variables. A8 displays the core regression specifications, but using an alternative version of our main independent variable (PI). A9 shows Placebo tests on outcomes we did not theoretically expect should be affected by PI. Finally, A10 includes a host of additional split-sample and interaction tests, further assessing the potential heterogeneity of the relationships between party institutionalization, on the one hand, and the different welfare state features, on the other. 


\section{Appendix A1: Measures}

Table A1. Variable definitions and sources for variables reported in the paper

\begin{tabular}{|c|c|}
\hline Variable: & Defintion \\
\hline $\begin{array}{l}\text { Party organizations } \\
\text { (v2psorgs) }\end{array}$ & $\begin{array}{l}\text { How many political parties for national-level office have permanent } \\
\text { organizations? A permanent organization connotes a substantial number of } \\
\text { personnel who are responsible for carrying out party activities outside of the } \\
\text { election season. Responses: (0) No parties. (1) Fewer than half of the parties. } \\
\text { (2) About half of the parties. (3) More than half of the parties. (4) All parties. }\end{array}$ \\
\hline $\begin{array}{l}\text { Party branches } \\
\text { (v2psprbrch) }\end{array}$ & $\begin{array}{l}\text { How many parties have permanent local party branches? Responses: (0) None. } \\
\text { (1) Fewer than half. (2) About half. (3) More than half. (4) All. }\end{array}$ \\
\hline $\begin{array}{l}\text { Party linkages } \\
\text { (v2psprlnks) }\end{array}$ & $\begin{array}{l}\text { Among the major parties, what is the main or most common form of linkage to } \\
\text { their constituents? A party-constituent linkage refers to the sort of "good" that } \\
\text { the party offers in exchange for political support and participation in party } \\
\text { activities. Responses: (0) Clientelistic. Constituents are rewarded with goods, } \\
\text { cash, and/or jobs. (1) Mixed clientelistic and local collective. (2) Local } \\
\text { collective. Constituents are rewarded with local collective goods, e.g., wells, } \\
\text { toilets, markets, roads, bridges, and local development. (3) Mixed local } \\
\text { collective and policy/programmatic. (4) Policy/programmatic. Constituents } \\
\text { respond to a party's positions on national policies, general party programs, and } \\
\text { visions for society. }\end{array}$ \\
\hline
\end{tabular}

Distinct platforms (v2psplats)

Legislative cohesion (v2pscohesv)

Party
institutionalization
index

Encompassingness

Universalism (v2dlunivl)
How many political parties with representation in the national legislature or presidency have publicly available party platforms (manifestos) that are publicized and relatively distinct from one another? In order to be counted in the affirmative, parties must have platforms that are both distinct (either in terms of content or generalized ideology) and publicly disseminated. This question is not intended to measure how much the public actually knows about these platforms or whether they are important in structuring policymaking. Responses: (0) None, or nearly none. (1) Fewer than half. (2) About half. (3) More than half. (4) All, or nearly all.

Is it normal for members of the legislature to vote with other members of their party on important bills? Responses: (0) Not really. Many members are elected as independents and party discipline is very weak. (1) More often than not. Members are more likely to vote with their parties than against them, but defections are common. (2) Mostly. Members vote with their parties most of the time. (3) Yes, absolutely. Members vote with their parties almost all the time.

To what extent are political parties institutionalized. PI is aggregated by summing across standardized versions of v2psorgs, v2psprbrch, v2psprlnks, v2psplats and v2pscohesv. This sum is then normalized to $0-1$ by using the cumulative density function.See main text for details.

The number of major national welfare programs, within six risk areas, that are enacted. For a program to count as "major", at least one out of a pre-defined set of relatively broad social groups needs to be covered. The relevant groups are the following: agricultural workers; industrial/production workers; smallfirm workers; self-employed; students; employers; temporary/casual workers; family/domestic workers. See main text for details.

How many welfare programs are means-tested and how many benefit all (or virtually all) members of the polity? A means-tested program targets poor,
Source

V-Dem

(Coppedge et al. 2016)

V-Dem

(Coppedge et al. 2016)

V-Dem

(Coppedge et al. 2016)

V-Dem

(Coppedge et al. 2016)

V-Dem (Coppedge et al. 2016)

SPAW, Rasmussen (2017)

V-Dem

(Coppedge et al. 
Universalism Index

RR Sickness

Coverage of labor force for sickness

Social expenditure

Population

GDP per capita

Polyarchy

BMR democracy needy, or otherwise underprivileged constituents. Cash-transfer programs are normally means-tested. A universal (non-means tested) program potentially benefits everyone. This includes free education, national health care schemes, and retirement programs. Granted, some may benefit more than others from these programs (e.g., when people with higher salaries get higher unemployment benefits). The key point is that practically everyone is a beneficiary, or potential beneficiary. The purpose of this question is not to gauge the size of the welfare state but rather its quality. Responses: (0) There are no, or extremely limited, welfare state policies (education, health, retirement, unemployment, poverty programs). (1) Almost all of the welfare state policies are means-tested. (2) Most welfare state policies means-tested, but a significant portion (e.g. $1 / 4$ or $1 / 3$ ) is universalistic and potentially benefits everyone in the population. (3) The welfare state policies are roughly evenly divided between means-tested and universalistic. (4) Most welfare state policies are universalistic, but a significant portion (e.g., $1 / 4$ or $1 / 3$ ) are means-tested. (5) Almost all welfare state policies are universal in character. Only a small portion is means-tested.

Additive index, aggregating across programs for six major areas of risk covered in SPAW. Each area is scored 0 if no program; 1 if program is means-tested according to some property criterion (income-based exclusions are not considered means-tested); 2 if one social group is covered by a contribution- or employment-based program; 3 if two groups are covered, etc. The social groups counted are agricultural workers; industrial/production workers; small-firm workers; self-employed; students; employers; temporary/casual workers; family/domestic workers. If the program automatically includes all citizens, 9 is given.

Percentage of net average workers wages replaced by net unemployment benefits

Percentage of labor force insured for scikness in state legislated insurance

Total social transfer spending divided by GDP, as defined by the ILO

The population count, log-transformed

Real, PPP-adjusted GDP per capita, log-transformed.

Democracy index from V-dem, capturing "electoral democracy": The electoral principle of democracy seeks to embody the core value of making rulers responsive to citizens, achieved through electoral competition for the electorate's approval under circumstances when suffrage is extensive; political and civil society organizations can operate freely; elections are clean and not marred by fraud or systematic irregularities; and elections affect the composition of the chief executive of the country. In between elections, there is freedom of expression and an independent media capable of presenting alternative views on matters of political relevance. In the VDem conceptual scheme, electoral democracy is understood as an essential element of any other conception of (representative) democracy - liberal, participatory, deliberative, egalitarian, or some other

Dichotomous democracy measure based on contestation and participation. Countries coded democratic have (1) political leaders that are chosen through free and fair elections and (2) a minimal level of suffrage.
SPAW, Rasmussen

Korpi and Palme (2007)

Korpi and Palme (2007)

Armingeon et. al

Miller (2015)

V-Dem (Coppedge et al. 2016)

V-Dem (Coppedge et al. 2016)

Boix, Miller \& Rosato (2013) 
Electoral rules

Urbanization

Openness

Income inequality

(Gini)

Family farms

Union density

Left

Inter-state. war

Civil war

Political corruption index

Impartial

Administration

Civil society participation index

Women political
What was the electoral system used in this election for the lower or unicameral chamber of the legislature? (MAJ, PR and Mixed)

The population living in areas classified as urban according to the criteria of each area or country

Imports and exports divided by GDP

Distribution of income within the population expressed as a Gini coefficient.

What percentage of (cultivated) land area is comprised of family farms?

Share of wage-and salary earners unionized

Left party control over the executive

Did the country participate in an international armed conflict? Coded 1 if the country participated in an international armed conflict in a given year, 0 otherwise.

Was there a civil war, if yes 1 and 0 otherwise. Civil war - at least one intra-state war with at least 1,000 battle deaths for each country-year.

How pervasive is political corruption? The directionality of the V-Dem corruption index runs from less corrupt to more corrupt (unlike the other VDem variables that generally run from less democratic to more democratic situation). The corruption index includes measures of six distinct types of corruption that cover both different areas and levels of the polity realm, distinguishing between executive, legislative and judicial corruption. Within the executive realm, the measures also distinguish between corruption mostly pertaining to bribery and corruption due to embezzlement. Finally, they differentiate between corruption in the highest echelons of the executive (at the level of the rulers/cabinet) on the one hand, and in the public sector at large on the other. The measures thus tap into several distinguished types of corruption: both 'petty' and 'grand'; both bribery and theft; both corruption aimed and influencing law making and that affecting implementation.

Are public officials rigorous and impartial in the performance of their duties? This question focuses on the extent to which public officials generally abide by the law and treat like cases alike, or conversely, the extent to which public administration is characterized by arbitrariness and biases (i.e., nepotism, cronyism, or discrimination).

Are major CSOs routinely consulted by policymaker; how large is the involvement of people in CSOs; are women prevented from participating; and is legislative candidate nomination within party organization highly decentralized or made through party primaries?

Are women descriptively represented in formal political positions? Women's
V-Dem

(Coppedge et al.

2016)

V-Dem

(Coppedge et al.

2016)

V-Dem

(Coppedge et al. 2016)

V-Dem

(Coppedge et al. 2016)

Vanhanen

Rasmussen \&

Pontusson

Brambor et al.( 2014)

V-Dem

(Coppedge et al. 2016)

V-Dem

(Coppedge et al. 2016)

V-Dem

(Coppedge et al. 2016)

V-Dem

(Coppedge et al. 2016)

V-Dem 
participation index

Regions

Military Expenditure

Military Expenditure in percent of GDP

political participation is understood to include women's descriptive representation in the legislature and an equal share in the overall distribution of power.

In which politico-geographic region is this country located?

Public order

spending
(Coppedge et al. 2016)

QOG Standard Dataset (Teorell et al. 2017)

QOG Standard Dataset (Teorell et al. 2017)

GSRE (Lucas and Richter 2016) 


\section{Appendix A2: Descriptive statistics}

Table A2. Descriptive statistics calculated for set of observations included in different model specifications in Table 1

\begin{tabular}{lcccc}
\hline Descriptive statistics model 2 & & & \\
& mean & sd & min & 6 \\
\hline Encompassing SPAW & 3.872116 & 1.813163 & 0 & .0094183 \\
Party instit. & .6008432 & .2814032 & 5.70711 & .9858114 \\
Population & 9.160203 & 1.32417 & 5.315224 & 13.82988 \\
GDP (Log) & 7.938213 & .9899841 & .0451607 & 10.31559 \\
Polyarchy & .4381009 & .2825434 & 0 & .9434598 \\
Electoral rules & .5159246 & .6277793 & & 2 \\
\hline
\end{tabular}

\begin{tabular}{|c|c|c|c|c|}
\hline \multicolumn{5}{|c|}{ Descriptive statistics model 5} \\
\hline & mean & sd & $\min$ & $\max$ \\
\hline Universalism v-dem & .4003045 & 1.256938 & -3.029935 & 3.232383 \\
\hline Party instit. & .5906694 & .2813186 & .0094183 & .9858114 \\
\hline Population & 9.101019 & 1.319481 & 5.70711 & 13.82988 \\
\hline GDP (Log) & 7.899548 & .9911748 & 5.315224 & 10.31559 \\
\hline Polyarchy & .4287395 & .2807155 & .0451607 & .9434598 \\
\hline Electoral rules & .4968474 & .6210276 & 0 & 2 \\
\hline \multicolumn{5}{|c|}{ Descriptive statistics model 7} \\
\hline & mean & sd & $\min$ & $\max$ \\
\hline Universalism SPAW & 14.65765 & 9.710052 & 0 & 44 \\
\hline Party instit. & .5572577 & .2858848 & .0094183 & .9858114 \\
\hline Population & 9.125517 & 1.298291 & 6.045005 & 13.81357 \\
\hline GDP (Log) & 7.807652 & .9138105 & 5.831149 & 10.2353 \\
\hline Polyarchy & .3879448 & .262731 & .0460888 & .9385647 \\
\hline Electoral rules & .5100671 & .615974 & 0 & 2 \\
\hline
\end{tabular}

\begin{tabular}{lcccc}
\hline Descriptive statistics model 8 & & & & \\
& mean & sd & min & $\max$ \\
\hline Replacement Rate & .4978774 & .2981646 & 0 & 1 \\
Party instit. & .8978448 & .0813805 & .3371783 & .9841773 \\
Population & 9.485884 & 1.266021 & 7.309212 & 12.53666 \\
GDP (Log) & 9.133489 & .6073762 & 7.340148 & 10.26472 \\
Polyarchy & .8103145 & .1329457 & .0561946 & .9410231 \\
Electoral rules & .6692015 & .5533401 & 0 & 2 \\
\hline
\end{tabular}

Descriptive statistics model 9

\begin{tabular}{lcccc} 
& mean & sd & $\min$ & $\max$ \\
\hline Coverage Rate & .5730861 & .3686468 & 0 & 1 \\
Party instit. & .8983119 & .0808401 & .3371783 & .9841773 \\
Population & 9.477103 & 1.255307 & 7.309212 & 12.53666 \\
GDP (Log) & 9.135121 & .6030734 & 7.340148 & 10.26472 \\
Polyarchy & .8109987 & .1320663 & .0561946 & .9410231 \\
Electoral rules & .6741573 & .5506377 & 0 & 2 \\
\hline
\end{tabular}

\begin{tabular}{lcccc}
\hline Descriptive statistics model 10 & & & \\
& mean & sd & $\min$ & $\max$ \\
\hline Social expenditure & 12.44573 & 3.87917 & 2.332729 & 23.40068 \\
Party instit. & .9133512 & .0665409 & .140586 & .9841773
\end{tabular}




\begin{tabular}{lcccc} 
Population & 9.539515 & 1.114413 & 7.77191 & 12.53718 \\
GDP (Log) & 9.508592 & .3669328 & 7.991538 & 10.31559 \\
Polyarchy & .8538067 & .1096984 & .0753926 & .9378571 \\
Electoral rules & .7784891 & .5343083 & 0 & 2 \\
\hline
\end{tabular}




\section{Appendix A3: Sample}

Table A3. Country years included in Model 1, Table 1

\begin{tabular}{|c|c|}
\hline Country: & Time Period \\
\hline Albania & $1914-2007$ \\
\hline Argentina & $1900-2007$ \\
\hline Armenia & $1992-2007$ \\
\hline Austria & $1918-1937 * 1947-2007$ \\
\hline Azerbaijan & $1992-2007$ \\
\hline Belarus & $1992-2007$ \\
\hline Belgium & $1900-2007$ \\
\hline Benin & 1960-1999 \\
\hline Bolivia & $1900-1999$ \\
\hline Brazil & $1900-2007$ \\
\hline Bulgaria & $1900-2007$ \\
\hline Burkina Faso & $1955-2007$ \\
\hline Burundi & 1950-1999 \\
\hline Cameroon & $1961-2000$ \\
\hline Cape Verde & $1976-2007$ \\
\hline Central African Republic & $1961-2007$ \\
\hline Chad & $1961-2000$ \\
\hline Chile & $1900-2007$ \\
\hline Colombia & 1900-1999 \\
\hline Congo & $1957-2000$ \\
\hline Costa Rica & $1900-2007$ \\
\hline Cote d'Ivoire & $1961-2000$ \\
\hline Cyprus & $1943-2007$ \\
\hline Czech Republic & $1994-2007$ \\
\hline Democratic Republic of Congo & $1961-2007$ \\
\hline Denmark & $1900-2007$ \\
\hline Dominican Republic & 1900-1931 \\
\hline Ecuador & $1900-2007$ \\
\hline El Salvador & $1900-2007$ \\
\hline Estonia & $1920-1939 *-2007$ \\
\hline Finland & $1908-2007$ \\
\hline France & $1900-2007$ \\
\hline Gabon & $1961-2007$ \\
\hline Gambia & $1966-2007$ \\
\hline Georgia & $1992-2007$ \\
\hline German Democratic Republic & 1950-1989 \\
\hline Germany & $1900-2007$ \\
\hline Ghana & $1958-2007$ \\
\hline Greece & $1900-2007$ \\
\hline Guatemala & $1900-2000$ \\
\hline Guyana & $1901-2007$ \\
\hline Haiti & $1900-2007$ \\
\hline Honduras & $1900-2007$ \\
\hline Hungary & $1919-2007$ \\
\hline Iceland & $1947-2007$ \\
\hline Ireland & 1919-1999 \\
\hline Italy & $1900-2007$ \\
\hline Kenya & $1964-2007$ \\
\hline Latvia & $1920-1939 * 1991-2007$ \\
\hline Liberia & $1900-2007$ \\
\hline Lithuania & $1920-1939 * 1991-2007$ \\
\hline Mali & $1961-2007$ \\
\hline Mauritania & $1961-2000$ \\
\hline Mexico & $1900-2007$ \\
\hline
\end{tabular}


Moldova

1992-2007

Netherlands

1900-2007

Nicaragua

1900-2007

Niger

1955-2007

Nigeria

1942-2007

Norway

1900-2007

Panama

1904-2007

Paraguay

1900-2007

Peru

1900-2007

Poland

1920-2007

Portugal

1900-2007

Romania

1900-2007

Russia

1900-2007

Rwanda

1963-2000

Senegal

1953-2007

Serbia

1900-2007

Slovak Republic

1994-2007

Slovenia

1992-2007

Spain

1900-2007

Sweden

1900-2006

Switzerland

1900-2007

Tanzania

1949-2007

Togo

1953-2011

Trinidad

1901-1949

Trinidad and Tobago

1950-2007

Uganda

1963-2000

Ukraine

1992-2007

United Kingdom

1900-2007

Uruguay

USA

1900-2007

Venezuela

Yugoslavia

1900-2007

1920-2007 


\section{Appendix A4: Additional analysis on different welfare measures}

\section{- alternative control strategies}

Table A4. Party institutionalization and universalism (Coverage) and generosity (Replacement rates), using CEWD data on sickness benefits programs. Time series extend from 1970- 2004

\begin{tabular}{|c|c|c|c|c|c|c|}
\hline Dependent variable & $\begin{array}{c}\text { (1) } \\
\mathrm{RR} \\
\text { for singles }\end{array}$ & $\begin{array}{c}(2) \\
\text { RR } \\
\text { for singles } \\
\end{array}$ & $\begin{array}{c}\text { (3) } \\
\text { RR } \\
\text { for Couples }\end{array}$ & $\begin{array}{c}\text { (4) } \\
\text { RR } \\
\text { for Couples }\end{array}$ & $\begin{array}{c}(5) \\
\text { Coverage }\end{array}$ & $\begin{array}{c}(6) \\
\text { Coverage }\end{array}$ \\
\hline Party inst. & $\begin{array}{l}0.092^{* *} \\
(2.66)\end{array}$ & $\begin{array}{l}0.045 \\
(0.70)\end{array}$ & $\begin{array}{l}0.075^{*} \\
(2.27)\end{array}$ & $\begin{array}{l}0.044 \\
(0.62)\end{array}$ & $\begin{array}{l}1.24^{* * *} \\
(4.06)\end{array}$ & $\begin{array}{l}1.20^{* *} \\
(2.91)\end{array}$ \\
\hline Polyarchy & & $\begin{array}{c}0.10 \\
(1.63)\end{array}$ & & $\begin{array}{l}0.16^{*} \\
(2.27)\end{array}$ & & $\begin{array}{l}-0.073 \\
(-1.09)\end{array}$ \\
\hline Population (logged) & & $\begin{array}{l}0.034 \\
(0.74)\end{array}$ & & $\begin{array}{l}0.090 \\
(1.40)\end{array}$ & & $\begin{array}{l}-0.078 \\
(-1.38)\end{array}$ \\
\hline GDP (log) & & $\begin{array}{l}0.50^{* * *} \\
(7.86)\end{array}$ & & $\begin{array}{l}0.19^{* *} \\
(3.09)\end{array}$ & & $\begin{array}{l}0.056 \\
(1.36)\end{array}$ \\
\hline PR & & $\begin{array}{c}-0.087^{* * *} \\
(-4.31)\end{array}$ & & $\begin{array}{l}-0.12^{* * *} \\
(-4.13)\end{array}$ & & $\begin{array}{l}0.021 \\
(1.13)\end{array}$ \\
\hline Mixed & & $\begin{array}{c}-0.040^{*} \\
(-2.35)\end{array}$ & & $\begin{array}{l}-0.045 \\
(-1.88)\end{array}$ & & $\begin{array}{l}0.028 \\
(1.89)\end{array}$ \\
\hline Country Dummies & Yes & Yes & Yes & Yes & Yes & Yes \\
\hline Year Dummies & Yes & Yes & Yes & Yes & Yes & Yes \\
\hline Observations & 764 & 594 & 764 & 594 & 700 & 554 \\
\hline
\end{tabular}


Table A5. Replicating main models using the SPAW Universalism Index as DV

\begin{tabular}{|c|c|c|c|}
\hline Level/Change DV & $\begin{array}{l}\text { (1) } \\
\mathrm{L}\end{array}$ & $\begin{array}{l}(2) \\
\mathrm{L}\end{array}$ & $\begin{array}{l}\text { (3) } \\
\mathrm{C}\end{array}$ \\
\hline Party ints. & $\begin{array}{c}2.63^{* * *} \\
(7.29)\end{array}$ & $\begin{array}{l}2.05^{* * *} \\
(5.24)\end{array}$ & $\begin{array}{l}0.061 \\
(0.40)\end{array}$ \\
\hline Polyarchy & & $\begin{array}{c}0.73 \\
(1.82)\end{array}$ & $\begin{array}{c}0.30 \\
(1.89)\end{array}$ \\
\hline Population (logged) & & $\begin{array}{l}1.12^{* * *} \\
(3.52)\end{array}$ & $\begin{array}{l}0.42^{* * *} \\
(3.51)\end{array}$ \\
\hline GDP (log) & & $\begin{array}{l}0.47^{*} \\
(2.10)\end{array}$ & $\begin{array}{c}0.19^{*} \\
(2.18)\end{array}$ \\
\hline PR & & $\begin{array}{l}0.53^{* *} \\
(2.69)\end{array}$ & $\begin{array}{l}0.065 \\
(0.82)\end{array}$ \\
\hline Mixed & & $\begin{array}{l}1.90^{* * *} \\
(7.52)\end{array}$ & $\begin{array}{c}0.13 \\
(1.08)\end{array}$ \\
\hline LDV & & & $\begin{array}{c}-0.13^{* * *} \\
(-9.93)\end{array}$ \\
\hline Country Dummies & Yes & Yes & Yes \\
\hline Year Dummies & Yes & Yes & Yes \\
\hline Observations & 4056 & 4056 & 4056 \\
\hline
\end{tabular}

T-values (in parentheses) calculated with panel corrected standard errors. ${ }^{*} p<0.05,{ }^{* *} p<0.01,{ }^{* * *} p<0.001$ 
Table A6. Replicating main models using public vs particularistic goods measure(v2dlencmps from V-Dem)

\begin{tabular}{|c|c|c|c|}
\hline Level/Change & $\begin{array}{l}\text { (1) } \\
\mathrm{L}\end{array}$ & $\begin{array}{l}(2) \\
\mathrm{L}\end{array}$ & $\begin{array}{l}\text { (3) } \\
\text { C }\end{array}$ \\
\hline Party ints. & $\begin{array}{l}1.54^{* * *} \\
(21.47)\end{array}$ & $\begin{array}{l}1.26^{* * *} \\
(16.46)\end{array}$ & $\begin{array}{l}0.22^{* * *} \\
(7.14)\end{array}$ \\
\hline Polyarchy & & $\begin{array}{c}0.57^{\text {*** }} \\
(9.00)\end{array}$ & $\begin{array}{l}0.025 \\
(0.98)\end{array}$ \\
\hline Population (logged) & & $\begin{array}{c}0.17^{\text {*** }} \\
(4.05)\end{array}$ & $\begin{array}{l}-0.021 \\
(-1.33)\end{array}$ \\
\hline GDP (log) & & $\begin{array}{l}0.080^{*} \\
(2.56)\end{array}$ & $\begin{array}{l}-0.017 \\
(-1.39)\end{array}$ \\
\hline PR & & $\begin{array}{l}-0.052 \\
(-1.50)\end{array}$ & $\begin{array}{c}0.0064 \\
(0.50)\end{array}$ \\
\hline Mixed & & $\begin{array}{c}-0.27^{* * *} \\
(-6.91)\end{array}$ & $\begin{array}{l}-0.025 \\
(-1.59)\end{array}$ \\
\hline LDV & & & $\begin{array}{c}-0.093^{* * *} \\
(-15.35)\end{array}$ \\
\hline Country Dummies & Yes & Yes & Yes \\
\hline Year Dummies & Yes & Yes & Yes \\
\hline Observations & 7124 & 7124 & 7124 \\
\hline
\end{tabular}

T-values (in parentheses) calculated with panel corrected standard errors. ${ }^{*} p<0.05,{ }^{* *} p<0.01,{ }^{* * *} p<0.001$ 
Table A7. Party institutionalization on various welfare state measures. Models without controls

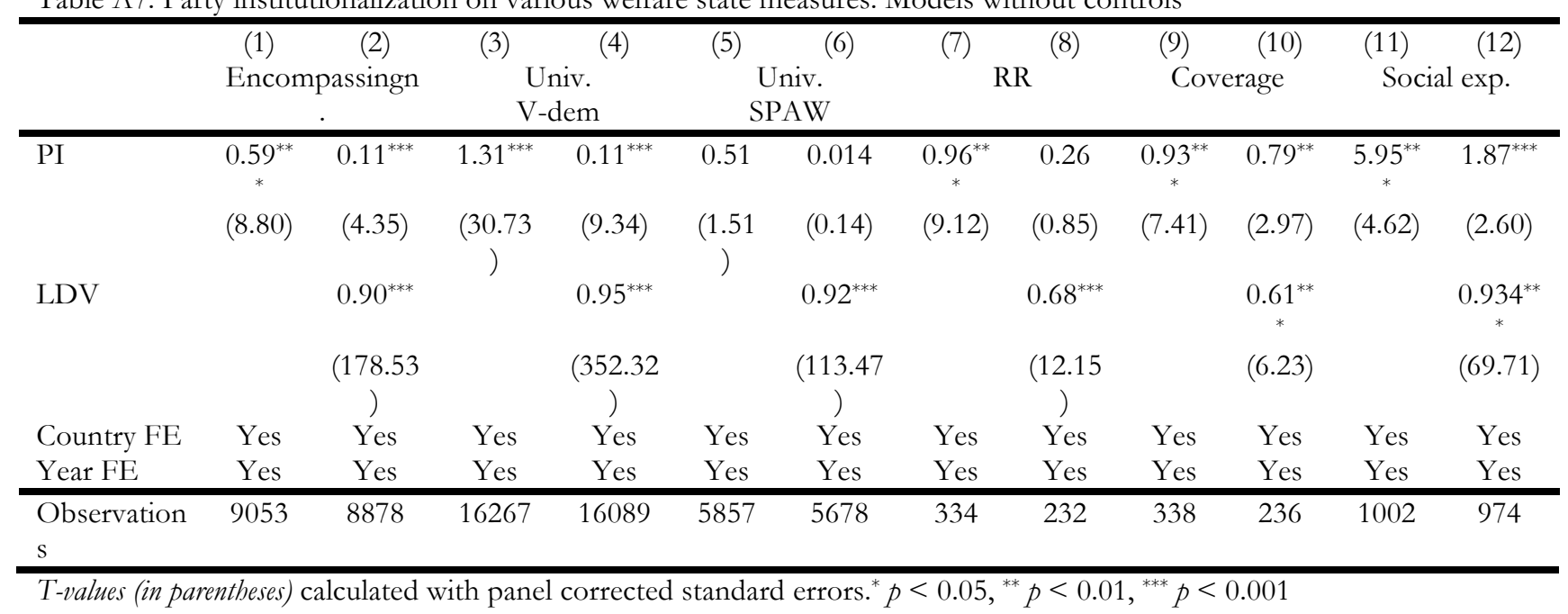


Table A8. Party institutionalization on welfare state universalism measures holding welfare state size constant.

\begin{tabular}{lcccccc}
\hline & Dependent variable: & \multicolumn{3}{c}{ V-dem Universalism } & \multicolumn{3}{c}{ SPAW Universalism } \\
& $(1)$ & $(2)$ & $(3)$ & $(4)$ & $(5)$ & $(6)$ \\
\hline Party instit. & $1.62^{* * *}$ & $1.48^{* * *}$ & $0.23^{* * *}$ & 0.20 & $1.41^{* * *}$ & 0.11 \\
& $(28.51)$ & $(18.11)$ & $(8.00)$ & $(0.74)$ & $(4.29)$ & $(0.72)$ \\
Number of major welfare laws & $0.097^{* * *}$ & $0.046^{* * *}$ & -0.0023 & $3.07^{* * *}$ & $3.15^{* * *}$ & $0.78^{* * *}$ \\
& $(11.51)$ & $(4.07)$ & $(-0.52)$ & $(53.33)$ & $(37.11)$ & $(14.74)$ \\
LDV & & & $-0.092^{* * *}$ & & & $-0.20^{* * *}$ \\
& & & $(-13.74)$ & & & $(-14.16)$ \\
Controls & No & Yes & Yes & No & Yes & Yes \\
Country Dummies & Yes & Yes & Yes & Yes & Yes & Yes \\
Year Dummies & Yes & Yes & Yes & Yes & Yes & Yes \\
\hline Observations & 9053 & 6154 & 6143 & 5674 & 4055 & 3939 \\
\hline
\end{tabular}

T-values (in parentheses) calculated with panel corrected standard errors. Constant, fixed time, country effects and controls (GDP [Log], population [Log], electoral rules and Polyarchy) excluded. ${ }^{*} p<0.05,{ }^{* *} p<0.01,{ }^{* * *} p<0.001$ 


\section{Appendix A5: Replicating indicator-specific tests (from Table 2 in paper) for all welfare measures}

\begin{tabular}{|c|c|c|c|c|c|c|}
\hline & (1) & (2) & (3) & (4) & (5) & (6) \\
\hline Party organizations & $\begin{array}{l}0.049^{* * *} \\
(3.60)\end{array}$ & & & & & $\begin{array}{l}-0.030 \\
(-1.53)\end{array}$ \\
\hline Party branches & & $\begin{array}{c}0.072^{* * *} \\
(4.81)\end{array}$ & & & & $\begin{array}{l}0.050^{*} \\
(2.25)\end{array}$ \\
\hline Party linkages & & & $\begin{array}{l}0.048^{* *} \\
(3.10)\end{array}$ & & & $\begin{array}{l}0.031 \\
(1.70)\end{array}$ \\
\hline Distinct party platforms & & & & $\begin{array}{c}0.062^{* * *} \\
(4.60)\end{array}$ & & $\begin{array}{l}0.040^{*} \\
(2.33)\end{array}$ \\
\hline Legislative party cohesion & & & & & $\begin{array}{c}0.081^{* * *} \\
(4.91)\end{array}$ & $\begin{array}{l}0.076^{* * *} \\
(4.36)\end{array}$ \\
\hline Pop & $\begin{array}{l}1.20^{* * *} \\
(27.50)\end{array}$ & $\begin{array}{l}1.18^{* * *} \\
(27.04)\end{array}$ & $\begin{array}{l}1.19^{* * *} \\
(27.33)\end{array}$ & $\begin{array}{l}1.19^{* * *} \\
(27.37)\end{array}$ & $\begin{array}{l}1.20^{* * *} \\
(27.63)\end{array}$ & $\begin{array}{l}1.18^{* * *} \\
(27.00)\end{array}$ \\
\hline GDP & $\begin{array}{l}0.19^{* * *} \\
(5.11)\end{array}$ & $\begin{array}{l}0.17^{* * *} \\
(4.79)\end{array}$ & $\begin{array}{l}0.18^{* * *} \\
(4.83)\end{array}$ & $\begin{array}{l}0.18^{* * *} \\
(4.97)\end{array}$ & $\begin{array}{l}0.17^{* * *} \\
(4.74)\end{array}$ & $\begin{array}{l}0.15^{* * *} \\
(4.15)\end{array}$ \\
\hline Polyarchy & $\begin{array}{c}-0.37^{* * *} \\
(-5.36)\end{array}$ & $\begin{array}{l}-0.39^{* * *} \\
(-5.69)\end{array}$ & $\begin{array}{l}-0.34^{* * *} \\
(-4.83)\end{array}$ & $\begin{array}{l}-0.39^{* * *} \\
(-5.44)\end{array}$ & $\begin{array}{l}-0.21^{* *} \\
(-3.03)\end{array}$ & $\begin{array}{l}-0.36^{* * *} \\
(-4.71)\end{array}$ \\
\hline PR & $\begin{array}{l}0.56^{* * *} \\
(16.42)\end{array}$ & $\begin{array}{l}0.56^{* * *} \\
(16.48)\end{array}$ & $\begin{array}{l}0.55^{* * *} \\
(15.63)\end{array}$ & $\begin{array}{l}0.54^{* * *} \\
(15.72)\end{array}$ & $\begin{array}{l}0.58^{* * *} \\
(16.48)\end{array}$ & $\begin{array}{l}0.56^{* * *} \\
(15.66)\end{array}$ \\
\hline Mixed & $\begin{array}{l}0.53^{* * *} \\
(11.51)\end{array}$ & $\begin{array}{l}0.52^{* * *} \\
(11.46)\end{array}$ & $\begin{array}{l}0.52^{* * *} \\
(11.42)\end{array}$ & $\begin{array}{l}0.51^{* * *} \\
(11.16)\end{array}$ & $\begin{array}{l}0.52^{* * *} \\
(11.43)\end{array}$ & $\begin{array}{l}0.51^{* * *} \\
(11.10)\end{array}$ \\
\hline $\begin{array}{l}\text { Country Dummies } \\
\text { Year Dummies }\end{array}$ & $\begin{array}{l}\text { Yes } \\
\text { Yes }\end{array}$ & $\begin{array}{l}\text { Yes } \\
\text { Yes }\end{array}$ & $\begin{array}{l}\text { Yes } \\
\text { Yes }\end{array}$ & $\begin{array}{l}\text { Yes } \\
\text { Yes }\end{array}$ & $\begin{array}{l}\text { Yes } \\
\text { Yes }\end{array}$ & $\begin{array}{l}\text { Yes } \\
\text { Yes }\end{array}$ \\
\hline Observations & 6154 & 6154 & 6142 & 6142 & 6110 & 6110 \\
\hline
\end{tabular}


Table A10. Party institutionalization indicators on SPAW Universalism Index

\begin{tabular}{|c|c|c|c|c|c|c|}
\hline & (1) & (2) & (3) & (4) & (5) & (6) \\
\hline Party organizations & $\begin{array}{l}0.26^{* * *} \\
(3.72)\end{array}$ & & & & & $\begin{array}{c}-0.16 \\
(-1.40)\end{array}$ \\
\hline Party branches & & $\begin{array}{l}0.48^{* * *} \\
(5.98)\end{array}$ & & & & $\begin{array}{l}0.50^{* * *} \\
(3.95)\end{array}$ \\
\hline Party linkages & & & $\begin{array}{c}0.23^{*} \\
(2.23)\end{array}$ & & & $\begin{array}{c}0.14 \\
(1.26)\end{array}$ \\
\hline Distinct party platforms & & & & $\begin{array}{l}0.39^{* * *} \\
(5.27)\end{array}$ & & $\begin{array}{c}0.14 \\
(1.43)\end{array}$ \\
\hline Legislative party cohesion & & & & & $\begin{array}{l}-0.085 \\
(-0.91)\end{array}$ & $\begin{array}{c}-0.11 \\
(-1.19)\end{array}$ \\
\hline Pop & $\begin{array}{l}0.95^{* *} \\
(2.97)\end{array}$ & $\begin{array}{c}0.77^{*} \\
(2.41)\end{array}$ & $\begin{array}{l}0.96^{* *} \\
(3.02)\end{array}$ & $\begin{array}{l}0.84^{* *} \\
(2.62)\end{array}$ & $\begin{array}{l}0.92^{* *} \\
(2.86)\end{array}$ & $\begin{array}{c}0.66^{*} \\
(2.08)\end{array}$ \\
\hline GDP & $\begin{array}{c}0.44 \\
(1.94)\end{array}$ & $\begin{array}{c}0.32 \\
(1.37)\end{array}$ & $\begin{array}{c}0.40 \\
(1.74)\end{array}$ & $\begin{array}{c}0.37 \\
(1.62)\end{array}$ & $\begin{array}{c}0.49^{*} \\
(2.14)\end{array}$ & $\begin{array}{c}0.28 \\
(1.19)\end{array}$ \\
\hline Polyarchy & $\begin{array}{l}1.05^{* *} \\
(2.62)\end{array}$ & $\begin{array}{c}0.67 \\
(1.68)\end{array}$ & $\begin{array}{l}1.37^{* * *} \\
(3.55)\end{array}$ & $\begin{array}{c}0.83^{*} \\
(2.05)\end{array}$ & $\begin{array}{l}1.44^{* * *} \\
(3.57)\end{array}$ & $\begin{array}{c}0.32 \\
(0.73)\end{array}$ \\
\hline PR & $\begin{array}{l}0.65^{* *} \\
(3.26)\end{array}$ & $\begin{array}{l}0.66^{* * *} \\
(3.33)\end{array}$ & $\begin{array}{l}0.56^{* *} \\
(2.78)\end{array}$ & $\begin{array}{l}0.58^{* *} \\
(2.92)\end{array}$ & $\begin{array}{l}0.65^{* *} \\
(3.24)\end{array}$ & $\begin{array}{l}0.60^{* *} \\
(2.96)\end{array}$ \\
\hline Mixed & $\begin{array}{l}2.12^{* * *} \\
(7.22)\end{array}$ & $\begin{array}{l}2.11^{* * *} \\
(7.13)\end{array}$ & $\begin{array}{c}2.11^{* * *} \\
(7.16)\end{array}$ & $\begin{array}{l}2.11^{* * *} \\
(7.17)\end{array}$ & $\begin{array}{l}2.14^{* * *} \\
(7.27)\end{array}$ & $\begin{array}{l}2.13^{* * *} \\
(7.15)\end{array}$ \\
\hline Country Dummies & Yes & Yes & Yes & Yes & Yes & Yes \\
\hline Year Dummies & Yes & Yes & Yes & Yes & Yes & Yes \\
\hline Observations & 4172 & 4172 & 4169 & 4169 & 4152 & 4152 \\
\hline
\end{tabular}

T-values (in parentheses) calculated with panel corrected standard errors. ${ }^{*} p<0.05,{ }^{* *} p<0.01,{ }^{* * *} p<0.001$ 
Table A11. Party institutionalization on replacement rates for sickness insurance (from SCIP)

\begin{tabular}{|c|c|c|c|c|c|c|}
\hline & (1) & $(2)$ & (3) & (4) & (5) & (6) \\
\hline Party organizations & $\begin{array}{l}0.30^{* * *} \\
(7.32)\end{array}$ & & & & & $\begin{array}{l}0.29^{* * *} \\
(6.91)\end{array}$ \\
\hline Party branches & & $\begin{array}{l}0.089^{*} \\
(2.45)\end{array}$ & & & & $\begin{array}{l}0.025 \\
(0.78)\end{array}$ \\
\hline Party linkages & & & $\begin{array}{l}0.11^{* * *} \\
(3.52)\end{array}$ & & & $\begin{array}{l}0.081^{* *} \\
(2.80)\end{array}$ \\
\hline Distinct party platforms & & & & $\begin{array}{l}0.090^{*} \\
(2.14)\end{array}$ & & $\begin{array}{l}-0.027 \\
(-0.71)\end{array}$ \\
\hline Legislative party cohesion & & & & & $\begin{array}{c}-0.0020 \\
(-0.07)\end{array}$ & $\begin{array}{l}0.014 \\
(0.61)\end{array}$ \\
\hline Pop & $\begin{array}{l}-0.12 \\
(-1.62)\end{array}$ & $\begin{array}{l}-0.11 \\
(-1.31)\end{array}$ & $\begin{array}{l}-0.18^{*} \\
(-2.16)\end{array}$ & $\begin{array}{l}-0.15 \\
(-1.81)\end{array}$ & $\begin{array}{l}-0.14 \\
(-1.56)\end{array}$ & $\begin{array}{l}-0.15^{*} \\
(-2.02)\end{array}$ \\
\hline GDP & $\begin{array}{l}0.057 \\
(1.22)\end{array}$ & $\begin{array}{l}0.022 \\
(0.36)\end{array}$ & $\begin{array}{l}0.042 \\
(0.80)\end{array}$ & $\begin{array}{l}0.069 \\
(1.25)\end{array}$ & $\begin{array}{l}0.063 \\
(1.11)\end{array}$ & $\begin{array}{l}0.026 \\
(0.53)\end{array}$ \\
\hline Polyarchy & $\begin{array}{l}-0.31^{* *} \\
(-2.69)\end{array}$ & $\begin{array}{l}-0.052 \\
(-0.38)\end{array}$ & $\begin{array}{c}-0.0036 \\
(-0.03)\end{array}$ & $\begin{array}{l}-0.10 \\
(-0.66)\end{array}$ & $\begin{array}{c}0.10 \\
(0.81)\end{array}$ & $\begin{array}{l}-0.34^{*} \\
(-2.47)\end{array}$ \\
\hline PR & $\begin{array}{l}0.064 \\
(1.06)\end{array}$ & $\begin{array}{c}0.13 \\
(1.70)\end{array}$ & $\begin{array}{c}0.12 \\
(1.50)\end{array}$ & $\begin{array}{c}0.14 \\
(1.87)\end{array}$ & $\begin{array}{c}0.13 \\
(1.49)\end{array}$ & $\begin{array}{l}0.067 \\
(1.03)\end{array}$ \\
\hline Mixed & $\begin{array}{c}-0.0017 \\
(-0.03)\end{array}$ & $\begin{array}{l}0.089 \\
(1.10)\end{array}$ & $\begin{array}{l}0.040 \\
(0.49)\end{array}$ & $\begin{array}{l}0.070 \\
(0.85)\end{array}$ & $\begin{array}{l}0.027 \\
(0.32)\end{array}$ & $\begin{array}{l}0.017 \\
(0.25)\end{array}$ \\
\hline $\begin{array}{l}\text { Country Dummies } \\
\text { Year Dummies }\end{array}$ & $\begin{array}{l}\text { Yes } \\
\text { Yes }\end{array}$ & $\begin{array}{l}\text { Yes } \\
\text { Yes }\end{array}$ & $\begin{array}{l}\text { Yes } \\
\text { Yes }\end{array}$ & $\begin{array}{l}\text { Yes } \\
\text { Yes }\end{array}$ & $\begin{array}{l}\text { Yes } \\
\text { Yes }\end{array}$ & $\begin{array}{l}\text { Yes } \\
\text { Yes }\end{array}$ \\
\hline Observations & 263 & 263 & 263 & 263 & 263 & 263 \\
\hline
\end{tabular}

T-values (in parentheses) calculated with panel corrected standard errors. ${ }^{*} p<0.05,{ }^{* *} p<0.01,{ }^{* * *} p<0.001$ 
Table A12. Party institutionalization indicators on coverage rates for sickness insurance (from SCIP)

\begin{tabular}{|c|c|c|c|c|c|c|}
\hline & (1) & (2) & (3) & (4) & (5) & (6) \\
\hline Party organizations & $\begin{array}{l}0.31^{* * *} \\
(6.36)\end{array}$ & & & & & $\begin{array}{l}0.29^{* * *} \\
(5.89)\end{array}$ \\
\hline Party branches & & $\begin{array}{l}0.037 \\
(1.07)\end{array}$ & & & & $\begin{array}{l}-0.061 \\
(-1.93)\end{array}$ \\
\hline Party linkages & & & $\begin{array}{l}0.13^{* * *} \\
(3.66)\end{array}$ & & & $\begin{array}{l}0.075^{*} \\
(2.25)\end{array}$ \\
\hline Distinct party platforms & & & & $\begin{array}{l}0.16^{* * *} \\
(3.46)\end{array}$ & & $\begin{array}{l}0.060 \\
(1.32)\end{array}$ \\
\hline Legislative party cohesion & & & & & $\begin{array}{l}-0.058^{*} \\
(-2.50)\end{array}$ & $\begin{array}{l}-0.040^{*} \\
(-1.97)\end{array}$ \\
\hline Pop & $\begin{array}{l}0.016 \\
(0.17)\end{array}$ & $\begin{array}{c}0.0084 \\
(0.07)\end{array}$ & $\begin{array}{l}-0.054 \\
(-0.51)\end{array}$ & $\begin{array}{l}-0.033 \\
(-0.31)\end{array}$ & $\begin{array}{l}0.038 \\
(0.32)\end{array}$ & $\begin{array}{l}-0.016 \\
(-0.17)\end{array}$ \\
\hline GDP & $\begin{array}{l}0.28^{* * *} \\
(5.84)\end{array}$ & $\begin{array}{l}0.27^{* * *} \\
(4.68)\end{array}$ & $\begin{array}{c}0.26^{* * *} \\
(5.12)\end{array}$ & $\begin{array}{l}0.30^{* * *} \\
(5.62)\end{array}$ & $\begin{array}{c}0.30^{* * *} \\
(5.35)\end{array}$ & $\begin{array}{c}0.31^{* * *} \\
(6.01)\end{array}$ \\
\hline Polyarchy & $\begin{array}{l}-0.22^{*} \\
(-2.05)\end{array}$ & $\begin{array}{c}0.14 \\
(1.09)\end{array}$ & $\begin{array}{l}0.080 \\
(0.77)\end{array}$ & $\begin{array}{l}-0.17 \\
(-1.05)\end{array}$ & $\begin{array}{c}0.18 \\
(1.93)\end{array}$ & $\begin{array}{l}-0.31^{*} \\
(-2.12)\end{array}$ \\
\hline PR & $\begin{array}{l}-0.13^{* *} \\
(-2.87)\end{array}$ & $\begin{array}{l}-0.066 \\
(-1.62)\end{array}$ & $\begin{array}{l}-0.077 \\
(-1.96)\end{array}$ & $\begin{array}{l}-0.043 \\
(-1.09)\end{array}$ & $\begin{array}{l}-0.12^{* *} \\
(-2.69)\end{array}$ & $\begin{array}{l}-0.16^{* *} \\
(-3.09)\end{array}$ \\
\hline Mixed & $\begin{array}{l}-0.13^{*} \\
(-2.49)\end{array}$ & $\begin{array}{l}-0.075 \\
(-1.37)\end{array}$ & $\begin{array}{l}-0.086 \\
(-1.96)\end{array}$ & $\begin{array}{l}-0.025 \\
(-0.52)\end{array}$ & $\begin{array}{l}-0.12^{* *} \\
(-2.69)\end{array}$ & $\begin{array}{l}-0.15^{* *} \\
(-2.64)\end{array}$ \\
\hline $\begin{array}{l}\text { Country Dummies } \\
\text { Year Dummies }\end{array}$ & $\begin{array}{l}\text { Yes } \\
\text { Yes }\end{array}$ & $\begin{array}{l}\text { Yes } \\
\text { Yes }\end{array}$ & $\begin{array}{l}\text { Yes } \\
\text { Yes }\end{array}$ & $\begin{array}{l}\text { Yes } \\
\text { Yes }\end{array}$ & $\begin{array}{l}\text { Yes } \\
\text { Yes }\end{array}$ & $\begin{array}{l}\text { Yes } \\
\text { Yes }\end{array}$ \\
\hline Observations & 267 & 267 & 267 & 267 & 267 & 267 \\
\hline
\end{tabular}

T-values (in parentheses) calculated with panel corrected standard errors. ${ }^{*} p<0.05,{ }^{* *} p<0.01,{ }^{* * *} p<0.001$ 
Table A13. Party institutionalization indicators on social security spending as share of GDP (from CPDS)

\begin{tabular}{|c|c|c|c|c|c|c|}
\hline & (1) & (2) & (3) & (4) & $(5)$ & $(6)$ \\
\hline Party organizations & $\begin{array}{l}-0.067 \\
(-0.23)\end{array}$ & & & & & $\begin{array}{c}-0.24 \\
(-0.75)\end{array}$ \\
\hline Party branches & & $\begin{array}{l}-0.068 \\
(-0.21)\end{array}$ & & & & $\begin{array}{c}0.10 \\
(0.27)\end{array}$ \\
\hline Party linkages & & & $\begin{array}{l}0.52^{*} \\
(2.12)\end{array}$ & & & $\begin{array}{c}0.47 \\
(1.78)\end{array}$ \\
\hline Distinct party platforms & & & & $\begin{array}{c}0.12 \\
(0.44)\end{array}$ & & $\begin{array}{l}-0.026 \\
(-0.09)\end{array}$ \\
\hline Legislative party cohesion & & & & & $\begin{array}{l}0.44^{*} \\
(2.43)\end{array}$ & $\begin{array}{l}0.39^{*} \\
(2.07)\end{array}$ \\
\hline Pop & $\begin{array}{l}-4.35^{* * *} \\
(-5.38)\end{array}$ & $\begin{array}{c}-4.40^{* * *} \\
(-5.16)\end{array}$ & $\begin{array}{c}-4.44^{* * *} \\
(-5.36)\end{array}$ & $\begin{array}{c}-4.39^{* * *} \\
(-5.34)\end{array}$ & $\begin{array}{l}-4.58^{* * *} \\
(-5.12)\end{array}$ & $\begin{array}{l}-4.53^{* * *} \\
(-4.80)\end{array}$ \\
\hline GDP & $\begin{array}{l}1.16 \\
(1.41)\end{array}$ & $\begin{array}{c}1.19 \\
(1.47)\end{array}$ & $\begin{array}{c}0.73 \\
(0.85)\end{array}$ & $\begin{array}{c}1.14 \\
(1.39)\end{array}$ & $\begin{array}{c}1.17 \\
(1.41)\end{array}$ & $\begin{array}{c}0.73 \\
(0.86)\end{array}$ \\
\hline Polyarchy & $\begin{array}{l}3.36^{* *} \\
(3.02)\end{array}$ & $\begin{array}{l}3.28^{* * *} \\
(3.39)\end{array}$ & $\begin{array}{l}2.88^{* * *} \\
(3.29)\end{array}$ & $\begin{array}{l}2.99^{* *} \\
(2.99)\end{array}$ & $\begin{array}{c}2.99^{* * *} \\
(3.50)\end{array}$ & $\begin{array}{l}3.32^{* *} \\
(2.78)\end{array}$ \\
\hline PR & $\begin{array}{l}-0.83 \\
(-1.42)\end{array}$ & $\begin{array}{l}-0.82 \\
(-1.35)\end{array}$ & $\begin{array}{l}-1.07 \\
(-1.87)\end{array}$ & $\begin{array}{l}-0.96 \\
(-1.52)\end{array}$ & $\begin{array}{l}-0.37 \\
(-0.58)\end{array}$ & $\begin{array}{c}-0.54 \\
(-0.78)\end{array}$ \\
\hline Mixed & $\begin{array}{l}-1.57^{* *} \\
(-2.99)\end{array}$ & $\begin{array}{l}-1.62^{* *} \\
(-2.86)\end{array}$ & $\begin{array}{c}-1.82^{* * *} \\
(-3.49)\end{array}$ & $\begin{array}{l}-1.64^{* *} \\
(-3.00)\end{array}$ & $\begin{array}{l}-1.24^{*} \\
(-2.29)\end{array}$ & $\begin{array}{l}-1.38^{*} \\
(-2.30)\end{array}$ \\
\hline $\begin{array}{l}\text { Country Dummies } \\
\text { Year Dummies }\end{array}$ & $\begin{array}{l}\text { Yes } \\
\text { Yes }\end{array}$ & $\begin{array}{l}\text { Yes } \\
\text { Yes }\end{array}$ & $\begin{array}{l}\text { Yes } \\
\text { Yes }\end{array}$ & $\begin{array}{l}\text { Yes } \\
\text { Yes }\end{array}$ & $\begin{array}{l}\text { Yes } \\
\text { Yes }\end{array}$ & $\begin{array}{l}\text { Yes } \\
\text { Yes }\end{array}$ \\
\hline Observations & 781 & 781 & 781 & 781 & 781 & 781 \\
\hline
\end{tabular}


Table A14. Party institutionalization indicators on public goods measure (from V-Dem)

\begin{tabular}{|c|c|c|c|c|c|c|}
\hline & (1) & (2) & (3) & (4) & $(5)$ & $(6)$ \\
\hline Party organizations & $\begin{array}{l}0.23^{* * *} \\
(15.86)\end{array}$ & & & & & $\begin{array}{l}0.13^{* * *} \\
(6.53)\end{array}$ \\
\hline Party branches & & $\begin{array}{l}0.25^{* * *} \\
(15.48)\end{array}$ & & & & $\begin{array}{l}0.14^{* * *} \\
(6.74)\end{array}$ \\
\hline Party linkages & & & $\begin{array}{l}0.38^{* * *} \\
(25.87)\end{array}$ & & & $\begin{array}{l}0.34^{* * *} \\
(22.23)\end{array}$ \\
\hline Distinct party platforms & & & & $\begin{array}{c}0.088^{* * *} \\
(5.66)\end{array}$ & & $\begin{array}{l}-0.17^{* * *} \\
(-10.22)\end{array}$ \\
\hline Legislative party cohesion & & & & & $\begin{array}{l}0.17^{* * *} \\
(11.09)\end{array}$ & $\begin{array}{l}0.11^{* * *} \\
(7.33)\end{array}$ \\
\hline Pop & $\begin{array}{l}0.23^{* * *} \\
(5.69)\end{array}$ & $\begin{array}{l}0.18^{* * *} \\
(4.38)\end{array}$ & $\begin{array}{l}0.21^{* * *} \\
(5.19)\end{array}$ & $\begin{array}{l}0.24^{* * *} \\
(5.66)\end{array}$ & $\begin{array}{l}0.25^{* * *} \\
(6.02)\end{array}$ & $\begin{array}{l}0.18^{* * *} \\
(4.62)\end{array}$ \\
\hline GDP & $\begin{array}{l}0.096^{* *} \\
(3.05)\end{array}$ & $\begin{array}{l}0.056 \\
(1.81)\end{array}$ & $\begin{array}{l}0.011 \\
(0.37)\end{array}$ & $\begin{array}{l}0.090^{* *} \\
(2.86)\end{array}$ & $\begin{array}{l}0.079^{*} \\
(2.48)\end{array}$ & $\begin{array}{c}-0.0034 \\
(-0.11)\end{array}$ \\
\hline Polyarchy & $\begin{array}{l}0.66^{* * *} \\
(10.55)\end{array}$ & $\begin{array}{l}0.69^{* * *} \\
(10.99)\end{array}$ & $\begin{array}{l}0.66^{* * *} \\
(10.53)\end{array}$ & $\begin{array}{l}0.92^{* * *} \\
(14.15)\end{array}$ & $\begin{array}{l}1.32^{* * *} \\
(21.19)\end{array}$ & $\begin{array}{l}0.75^{* * *} \\
(11.53)\end{array}$ \\
\hline PR & $\begin{array}{l}-0.031 \\
(-0.89)\end{array}$ & $\begin{array}{l}-0.031 \\
(-0.91)\end{array}$ & $\begin{array}{l}-0.12^{* * *} \\
(-3.37)\end{array}$ & $\begin{array}{l}-0.048 \\
(-1.35)\end{array}$ & $\begin{array}{l}0.0010 \\
(0.03)\end{array}$ & $\begin{array}{l}-0.064 \\
(-1.94)\end{array}$ \\
\hline Mixed & $\begin{array}{l}-0.25^{* * *} \\
(-6.53)\end{array}$ & $\begin{array}{l}-0.26^{* * *} \\
(-6.77)\end{array}$ & $\begin{array}{l}-0.29^{* * *} \\
(-7.47)\end{array}$ & $\begin{array}{l}-0.28^{* * *} \\
(-6.93)\end{array}$ & $\begin{array}{l}-0.27^{* * *} \\
(-7.04)\end{array}$ & $\begin{array}{l}-0.27^{* * *} \\
(-7.26)\end{array}$ \\
\hline $\begin{array}{l}\text { Country Dummies } \\
\text { Year Dummies }\end{array}$ & $\begin{array}{l}\text { Yes } \\
\text { Yes }\end{array}$ & $\begin{array}{l}\text { Yes } \\
\text { Yes }\end{array}$ & $\begin{array}{l}\text { Yes } \\
\text { Yes }\end{array}$ & $\begin{array}{l}\text { Yes } \\
\text { Yes }\end{array}$ & $\begin{array}{l}\text { Yes } \\
\text { Yes }\end{array}$ & $\begin{array}{l}\text { Yes } \\
\text { Yes }\end{array}$ \\
\hline Observations & 7137 & 7137 & 7125 & 7125 & 7093 & 7093 \\
\hline
\end{tabular}

T-values (in parentheses) calculated with panel corrected standard errors. ${ }^{*} p<0.05,{ }^{* *} p<0.01,{ }^{* * *} p<0.001$ 


\section{Appendix A6: Replicating core robustness tests (from Table 3 in paper) for all welfare measures, plus tests on alternative control sets}

Table A15. Party institutionalization on Encompassingness (from SPAW)

\begin{tabular}{|c|c|c|c|c|c|c|c|c|c|}
\hline & Baseline & $\begin{array}{c}(2) \\
5 \text { year } \\
\text { lag }\end{array}$ & $\begin{array}{c}(3) \\
10 \text { year } \\
\text { lag }\end{array}$ & $\begin{array}{c}(4) \\
\text { Socio- } \\
\text { econ. } \\
\text { controls }\end{array}$ & $\begin{array}{c}(5) \\
\text { Work. } \\
\text { class } \\
\text { controls }\end{array}$ & $\begin{array}{c}(6) \\
\text { Instit. and } \\
\text { civil society } \\
\text { controls }\end{array}$ & $\begin{array}{c}(7) \\
\text { First } \\
\text { component } \\
\text { PI }\end{array}$ & $\begin{array}{c}\text { (8) } \\
\text { Control } \\
\text { linkages }\end{array}$ & $\begin{array}{c}(9) \\
\text { Random } \\
\text { effects } \\
\text { model }\end{array}$ \\
\hline Party Instit. & $\begin{array}{l}0.42^{* * *} \\
(5.85)\end{array}$ & $\begin{array}{l}0.26^{* * *} \\
(4.02)\end{array}$ & $\begin{array}{l}0.29^{* * *} \\
(4.65)\end{array}$ & $\begin{array}{c}0.11 \\
(1.60)\end{array}$ & $\begin{array}{l}1.40^{* * *} \\
(8.09)\end{array}$ & $\begin{array}{c}0.44^{* * *} \\
(5.51)\end{array}$ & $\begin{array}{c}0.088^{* * *} \\
(6.16)\end{array}$ & $\begin{array}{l}0.39^{* * *} \\
(4.80)\end{array}$ & $\begin{array}{c}0.48 \\
(1.84)\end{array}$ \\
\hline Polyarchy & $\begin{array}{c}-0.44^{* * *} \\
(-6.30)\end{array}$ & $\begin{array}{c}-0.26^{* * *} \\
(-3.98)\end{array}$ & $\begin{array}{c}-0.21^{* * *} \\
(-3.36)\end{array}$ & $\begin{array}{l}-0.19^{* *} \\
(-3.22)\end{array}$ & $\begin{array}{l}-0.41^{* *} \\
(-2.84)\end{array}$ & $\begin{array}{l}-0.43^{\text {*** }} \\
(-3.69)\end{array}$ & $\begin{array}{c}-0.45^{* * *} \\
(-6.26)\end{array}$ & $\begin{array}{c}-0.45^{* * *} \\
(-6.24)\end{array}$ & $\begin{array}{l}-0.47^{* *} \\
(-2.72)\end{array}$ \\
\hline Population & $\begin{array}{l}1.17^{* * *} \\
(26.99)\end{array}$ & $\begin{array}{l}1.21^{* * *} \\
(27.79)\end{array}$ & $\begin{array}{l}1.24^{* * *} \\
(27.32)\end{array}$ & $\begin{array}{l}0.75^{* * *} \\
(11.19)\end{array}$ & $\begin{array}{l}1.08^{* * *} \\
(10.22)\end{array}$ & $\begin{array}{l}1.23^{* * *} \\
(26.75)\end{array}$ & $\begin{array}{l}1.18^{* * *} \\
(27.26)\end{array}$ & $\begin{array}{l}1.17^{* * *} \\
(26.97)\end{array}$ & $\begin{array}{l}0.88^{* * *} \\
(6.77)\end{array}$ \\
\hline GDP & $\begin{array}{l}0.18^{* * *} \\
(4.98)\end{array}$ & $\begin{array}{c}0.21^{* * *} \\
(5.80)\end{array}$ & $\begin{array}{c}0.22^{* * *} \\
(5.98)\end{array}$ & $\begin{array}{l}0.45^{* * *} \\
(9.02)\end{array}$ & $\begin{array}{l}-0.028 \\
(-0.30)\end{array}$ & $\begin{array}{l}0.12^{* *} \\
(2.89)\end{array}$ & $\begin{array}{l}0.17^{* * *} \\
(4.63)\end{array}$ & $\begin{array}{l}0.18^{* * *} \\
(4.86)\end{array}$ & $\begin{array}{c}0.19 \\
(1.19)\end{array}$ \\
\hline PR & $\begin{array}{l}0.55^{* * *} \\
(16.22)\end{array}$ & $\begin{array}{l}0.52^{* * *} \\
(15.55)\end{array}$ & $\begin{array}{l}0.52^{* * *} \\
(15.40)\end{array}$ & $\begin{array}{l}0.17^{* * *} \\
(4.58)\end{array}$ & $\begin{array}{l}0.51^{* * *} \\
(7.20)\end{array}$ & $\begin{array}{l}0.53^{* * *} \\
(13.86)\end{array}$ & $\begin{array}{l}0.55^{\text {*** }} \\
(15.94)\end{array}$ & $\begin{array}{l}0.55^{* * *} \\
(15.67)\end{array}$ & $\begin{array}{l}0.62^{* * *} \\
(4.55)\end{array}$ \\
\hline Mixed & $\begin{array}{l}0.52^{* * *} \\
(11.37)\end{array}$ & $\begin{array}{l}0.46^{* * *} \\
(10.90)\end{array}$ & $\begin{array}{l}0.46^{* * *} \\
(10.82)\end{array}$ & $\begin{array}{l}0.15^{* *} \\
(2.77)\end{array}$ & $\begin{array}{l}0.78^{* * *} \\
(8.35)\end{array}$ & $\begin{array}{l}0.46^{* * *} \\
(9.60)\end{array}$ & $\begin{array}{l}0.52^{* * *} \\
(11.26)\end{array}$ & $\begin{array}{c}0.52^{* * *} \\
(11.30)\end{array}$ & $\begin{array}{l}0.55^{* * *} \\
(3.85)\end{array}$ \\
\hline Urbaniz & & & & $\begin{array}{c}-5.8 \mathrm{e}- \\
09^{* * *} \\
(-9.01)\end{array}$ & & & & & \\
\hline Openness & & & & $\begin{array}{c}0.0061^{* * *} \\
(3.31)\end{array}$ & & & & & \\
\hline Income ineq. & & & & $\begin{array}{c}0.013^{* * *} \\
(9.00)\end{array}$ & & & & & \\
\hline Fam. farms & & & & $\begin{array}{c}0.0035^{* * *} \\
(3.52)\end{array}$ & & & & & \\
\hline Union Dens. & & & & & $\begin{array}{c}0.0045^{* * *} \\
(4.09)\end{array}$ & & & & \\
\hline Left & & & & & $\begin{array}{l}-0.027 \\
(-0.80)\end{array}$ & & & & \\
\hline Inter-st. war & & & & & & $\begin{array}{l}-0.088^{*} \\
(-2.15)\end{array}$ & & & \\
\hline Civil war & & & & & & $\begin{array}{l}-0.016 \\
(-0.36)\end{array}$ & & & \\
\hline Corruption & & & & & & $\begin{array}{l}-0.21 \\
(-1.62)\end{array}$ & & & \\
\hline Imp. Admin. & & & & & & $\begin{array}{c}0.097^{* * *} \\
(4.95)\end{array}$ & & & \\
\hline Female parti. & & & & & & $\begin{array}{l}-0.92^{* * *} \\
(-10.31)\end{array}$ & & & \\
\hline Civil society & & & & & & $\begin{array}{l}-0.21^{*} \\
(-2.02)\end{array}$ & & & \\
\hline Party linkages & & & & & & & & $\begin{array}{l}0.013 \\
(0.76)\end{array}$ & \\
\hline $\begin{array}{l}\text { Country } \\
\text { Dummies }\end{array}$ & Yes & Yes & Yes & Yes & Yes & Yes & Yes & Yes & No \\
\hline $\begin{array}{l}\text { Year } \\
\text { Dummies }\end{array}$ & Yes & Yes & Yes & Yes & Yes & Yes & Yes & Yes & Yes \\
\hline Observations & 6154 & 6009 & 5796 & 3663 & 1496 & 5287 & 6110 & 6142 & 6154 \\
\hline
\end{tabular}


Table A16. Party institutionalization on Universalism Index (from SPAW)

\begin{tabular}{|c|c|c|c|c|c|c|c|c|c|}
\hline & Baseline & $\begin{array}{c}(2) \\
5 \text { year } \\
\text { lag }\end{array}$ & $\begin{array}{c}(3) \\
10 \\
\text { year } \\
\text { lag }\end{array}$ & $\begin{array}{c}\text { (4) } \\
\text { Socio- } \\
\text { econ. controls }\end{array}$ & $\begin{array}{c}(5) \\
\text { Work. } \\
\text { class } \\
\text { controls }\end{array}$ & $\begin{array}{c}(6) \\
\text { Instit. and } \\
\text { civil society } \\
\text { controls }\end{array}$ & $\begin{array}{c}(7) \\
\text { First } \\
\text { component } \\
\text { PI }\end{array}$ & $\begin{array}{c}\text { (8) } \\
\text { Control } \\
\text { linkages }\end{array}$ & $\begin{array}{c}(9) \\
\text { Random } \\
\text { effects } \\
\text { model }\end{array}$ \\
\hline Party Instit. & $\begin{array}{l}1.90^{* * *} \\
(4.81)\end{array}$ & $\begin{array}{l}1.24^{* * *} \\
(3.43)\end{array}$ & $\begin{array}{c}0.39 \\
(1.12)\end{array}$ & $\begin{array}{l}-0.080 \\
(-0.19)\end{array}$ & $\begin{array}{l}9.69^{* * *} \\
(4.22)\end{array}$ & $\begin{array}{l}2.02^{* * *} \\
(4.65)\end{array}$ & $\begin{array}{l}0.42^{* * *} \\
(5.33)\end{array}$ & $\begin{array}{l}1.75^{* * *} \\
(4.00)\end{array}$ & $\begin{array}{c}2.05 \\
(1.36)\end{array}$ \\
\hline Polyarchy & $\begin{array}{c}0.70 \\
(1.69)\end{array}$ & $\begin{array}{l}1.56^{* * *} \\
(4.26)\end{array}$ & $\begin{array}{l}1.95^{* * *} \\
(5.40)\end{array}$ & $\begin{array}{c}0.41 \\
(0.94)\end{array}$ & $\begin{array}{c}-7.83^{* * *} \\
(-3.49)\end{array}$ & $\begin{array}{c}0.68 \\
(1.02)\end{array}$ & $\begin{array}{l}0.81^{*} \\
(2.03)\end{array}$ & $\begin{array}{c}0.70 \\
(1.70)\end{array}$ & $\begin{array}{c}0.85 \\
(0.62)\end{array}$ \\
\hline Population & $\begin{array}{l}0.81^{*} \\
(2.56)\end{array}$ & $\begin{array}{l}0.88^{* *} \\
(2.82)\end{array}$ & $\begin{array}{l}0.75^{*} \\
(2.36)\end{array}$ & $\begin{array}{l}-0.17 \\
(-0.32)\end{array}$ & $\begin{array}{l}4.96^{* *} \\
(3.29)\end{array}$ & $\begin{array}{l}1.40^{* * *} \\
(4.30)\end{array}$ & $\begin{array}{l}0.86^{* *} \\
(2.70)\end{array}$ & $\begin{array}{l}0.83^{* *} \\
(2.59)\end{array}$ & $\begin{array}{c}0.82 \\
(0.96)\end{array}$ \\
\hline GDP & $\begin{array}{c}0.40 \\
(1.76)\end{array}$ & $\begin{array}{l}0.45^{*} \\
(2.11)\end{array}$ & $\begin{array}{c}0.34 \\
(1.57)\end{array}$ & $\begin{array}{l}1.29^{* * *} \\
(4.80)\end{array}$ & $\begin{array}{l}-0.25 \\
(-0.20)\end{array}$ & $\begin{array}{l}0.088 \\
(0.36)\end{array}$ & $\begin{array}{c}0.38 \\
(1.67)\end{array}$ & $\begin{array}{c}0.38 \\
(1.65)\end{array}$ & $\begin{array}{c}1.04 \\
(1.08)\end{array}$ \\
\hline PR & $\begin{array}{l}0.63^{* *} \\
(3.17)\end{array}$ & $\begin{array}{l}0.51^{* *} \\
(2.63)\end{array}$ & $\begin{array}{l}0.54^{* *} \\
(2.71)\end{array}$ & $\begin{array}{l}-0.24 \\
(-1.01)\end{array}$ & $\begin{array}{l}-0.96 \\
(-1.20)\end{array}$ & $\begin{array}{l}0.79^{* * *} \\
(3.64)\end{array}$ & $\begin{array}{l}0.63^{* *} \\
(3.16)\end{array}$ & $\begin{array}{l}0.60^{* *} \\
(2.97)\end{array}$ & $\begin{array}{c}0.84 \\
(1.32)\end{array}$ \\
\hline Mixed & $\begin{array}{l}2.13^{* * *} \\
(7.22)\end{array}$ & $\begin{array}{l}1.81^{* * *} \\
(7.66)\end{array}$ & $\begin{array}{l}1.91^{* * *} \\
(7.92)\end{array}$ & $\begin{array}{l}1.27^{* * *} \\
(3.68)\end{array}$ & $\begin{array}{l}-1.20 \\
(-1.28)\end{array}$ & $\begin{array}{l}2.42^{* * *} \\
(8.05)\end{array}$ & $\begin{array}{l}2.09^{* * *} \\
(7.09)\end{array}$ & $\begin{array}{l}2.12^{* * *} \\
(7.19)\end{array}$ & $\begin{array}{l}2.28^{* *} \\
(2.63)\end{array}$ \\
\hline Urbaniz & & & & $\begin{array}{c}- \\
0.000000060^{* * *} \\
(-11.43)\end{array}$ & & & & & \\
\hline Openness & & & & $\begin{array}{l}0.043^{*} \\
(2.29)\end{array}$ & & & & & \\
\hline Income ineq. & & & & $\begin{array}{c}0.0074 \\
(0.72)\end{array}$ & & & & & \\
\hline Fam. farms & & & & $\begin{array}{c}-0.0068 \\
(-0.97)\end{array}$ & & & & & \\
\hline Union Dens. & & & & & $\begin{array}{c}0.092^{* * *} \\
(5.06)\end{array}$ & & & & \\
\hline Left & & & & & $\begin{array}{l}1.04^{*} \\
(2.29)\end{array}$ & & & & \\
\hline Inter-st. war & & & & & & $\begin{array}{l}-1.24^{* * *} \\
(-4.82)\end{array}$ & & & \\
\hline Civil war & & & & & & $\begin{array}{c}0.26 \\
(1.33)\end{array}$ & & & \\
\hline Corruption & & & & & & $\begin{array}{l}-1.58^{*} \\
(-2.13)\end{array}$ & & & \\
\hline Imp. Admin. & & & & & & $\begin{array}{l}0.80^{* * * *} \\
(6.95)\end{array}$ & & & \\
\hline Female parti. & & & & & & $\begin{array}{l}-1.23^{*} \\
(-2.07)\end{array}$ & & & \\
\hline Civil society & & & & & & $\begin{array}{l}-3.27^{* * *} \\
(-6.23)\end{array}$ & & & \\
\hline Party linkages & & & & & & & & $\begin{array}{l}0.091 \\
(0.82)\end{array}$ & \\
\hline $\begin{array}{l}\text { Country } \\
\text { Dummies }\end{array}$ & Yes & Yes & Yes & Yes & Yes & Yes & Yes & Yes & No \\
\hline $\begin{array}{l}\text { Year } \\
\text { Dummies }\end{array}$ & Yes & Yes & Yes & Yes & Yes & Yes & Yes & Yes & Yes \\
\hline Observations & 4172 & 4075 & 3930 & 2416 & 743 & 3512 & 4152 & 4169 & 4172 \\
\hline
\end{tabular}


Table A17. Party Institutionalization on replacement rates for sickness insurance (from SCIP)

\begin{tabular}{|c|c|c|c|c|c|c|c|c|c|}
\hline & Baseline & $\begin{array}{c}(2) \\
5 \text { year } \\
\text { lag }\end{array}$ & $\begin{array}{c}(3) \\
10 \\
\text { year } \\
\text { lag }\end{array}$ & $\begin{array}{c}(4) \\
\text { Socio- } \\
\text { econ. } \\
\text { controls }\end{array}$ & $\begin{array}{c}(5) \\
\text { Work. } \\
\text { class } \\
\text { controls }\end{array}$ & $\begin{array}{c}(6) \\
\text { Instit. and } \\
\text { civil society } \\
\text { controls }\end{array}$ & $\begin{array}{c}(7) \\
\text { First } \\
\text { component } \\
\text { PI }\end{array}$ & $\begin{array}{c}\text { (8) } \\
\text { Control } \\
\text { linkages }\end{array}$ & $\begin{array}{c}(9) \\
\text { Random } \\
\text { effects } \\
\text { model }\end{array}$ \\
\hline Party Instit. & $1.63^{* * *}$ & 0.19 & 0.077 & $1.57^{*}$ & $1.61^{* * *}$ & $1.76^{* * *}$ & $0.28^{* * *}$ & $1.57^{* * *}$ & $1.61^{* * *}$ \\
\hline & $(8.03)$ & $(1.77)$ & $(0.88)$ & $(2.27)$ & $(8.41)$ & $(6.48)$ & $(6.08)$ & $(7.21)$ & $(3.30)$ \\
\hline Polyarchy & $\begin{array}{l}-0.54^{* * *} \\
(-3.86)\end{array}$ & $\begin{array}{l}0.038 \\
(0.29)\end{array}$ & $\begin{array}{l}0.095 \\
(0.76)\end{array}$ & $\begin{array}{l}-0.32 \\
(-1.09)\end{array}$ & $\begin{array}{l}-0.33^{*} \\
(-2.56)\end{array}$ & $\begin{array}{l}-0.54^{* *} \\
(-3.28)\end{array}$ & $\begin{array}{l}-0.41^{* *} \\
(-2.96)\end{array}$ & $\begin{array}{c}-0.54^{* * *} \\
(-3.84)\end{array}$ & $\begin{array}{l}-0.52 \\
(-1.61)\end{array}$ \\
\hline Pop. (ln) & $\begin{array}{l}-0.19^{*} \\
(-2.31)\end{array}$ & $\begin{array}{l}-0.14 \\
(-1.61)\end{array}$ & $\begin{array}{c}-0.13 \\
(-1.56)\end{array}$ & $\begin{array}{l}-0.32^{*} \\
(-2.04)\end{array}$ & $\begin{array}{l}-0.10 \\
(-1.28)\end{array}$ & $\begin{array}{l}-0.28^{* *} \\
(-3.20)\end{array}$ & $\begin{array}{l}-0.20^{*} \\
(-2.41)\end{array}$ & $\begin{array}{l}-0.19^{*} \\
(-2.36)\end{array}$ & $\begin{array}{l}-0.050 \\
(-0.95)\end{array}$ \\
\hline GDP pc (ln) & $\begin{array}{l}0.018 \\
(0.37)\end{array}$ & $\begin{array}{l}0.038 \\
(0.61)\end{array}$ & $\begin{array}{l}0.049 \\
(0.86)\end{array}$ & $\begin{array}{l}0.043 \\
(0.41)\end{array}$ & $\begin{array}{l}-0.034 \\
(-0.72)\end{array}$ & $\begin{array}{l}0.040 \\
(0.70)\end{array}$ & $\begin{array}{c}-0.00076 \\
(-0.01)\end{array}$ & $\begin{array}{l}0.016 \\
(0.33)\end{array}$ & $\begin{array}{l}-0.018 \\
(-0.15)\end{array}$ \\
\hline PR & $\begin{array}{l}0.071 \\
(1.26)\end{array}$ & $\begin{array}{c}0.15 \\
(1.76)\end{array}$ & $\begin{array}{c}0.13 \\
(1.53)\end{array}$ & $\begin{array}{l}-0.30^{*} \\
(-2.21)\end{array}$ & $\begin{array}{l}0.033 \\
(0.61)\end{array}$ & $\begin{array}{c}0.13 \\
(1.70)\end{array}$ & $\begin{array}{l}0.17^{*} \\
(2.46)\end{array}$ & $\begin{array}{l}0.072 \\
(1.26)\end{array}$ & $\begin{array}{l}0.13^{*} \\
(2.30)\end{array}$ \\
\hline Mixed & $\begin{array}{c}0.12 \\
(1.95)\end{array}$ & $\begin{array}{l}0.051 \\
(0.61)\end{array}$ & $\begin{array}{l}0.035 \\
(0.41)\end{array}$ & $\begin{array}{l}-0.20 \\
(-1.58)\end{array}$ & $\begin{array}{l}0.080 \\
(1.34)\end{array}$ & $\begin{array}{l}0.17^{*} \\
(2.26)\end{array}$ & $\begin{array}{l}0.15^{*} \\
(2.08)\end{array}$ & $\begin{array}{c}0.12 \\
(1.93)\end{array}$ & $\begin{array}{c}0.19 \\
(1.84)\end{array}$ \\
\hline Urbaniz. & & & & $\begin{array}{c}5.9 \mathrm{e}-10 \\
(0.33)\end{array}$ & & & & & \\
\hline Openness & & & & $\begin{array}{c}-0.0086^{* *} \\
(-2.96)\end{array}$ & & & & & \\
\hline Income ineq. & & & & $\begin{array}{c}-0.00010 \\
(-0.06)\end{array}$ & & & & & \\
\hline Fam. farms & & & & $\begin{array}{c}-0.00088 \\
(-0.36)\end{array}$ & & & & & \\
\hline Union dens. & & & & & $\begin{array}{c}0.0054^{* * *} \\
(6.36)\end{array}$ & & & & \\
\hline Left & & & & & $\begin{array}{c}0.0078 \\
(0.41)\end{array}$ & & & & \\
\hline Corruption & & & & & & $\begin{array}{l}-0.74 \\
(-1.73)\end{array}$ & & & \\
\hline Imp. Admin. & & & & & & $\begin{array}{l}0.037 \\
(1.41)\end{array}$ & & & \\
\hline Civil society & & & & & & $\begin{array}{l}-0.047 \\
(-0.43)\end{array}$ & & & \\
\hline Female parti. & & & & & & $\begin{array}{l}-0.60^{* * *} \\
(-3.32)\end{array}$ & & & \\
\hline Party link. & & & & & & & & $\begin{array}{l}0.019 \\
(0.60)\end{array}$ & \\
\hline $\begin{array}{l}\text { Country } \\
\text { Dummies }\end{array}$ & Yes & Yes & Yes & Yes & Yes & Yes & Yes & Yes & No \\
\hline $\begin{array}{l}\text { Year } \\
\text { Dummies }\end{array}$ & Yes & Yes & Yes & Yes & Yes & Yes & Yes & Yes & Yes \\
\hline Observations & 263 & 261 & 261 & 182 & 250 & 263 & 263 & 263 & 263 \\
\hline
\end{tabular}

T-values (in parentheses) calculated with panel corrected standard errors. ${ }^{*} p<0.05,{ }^{* *} p<0.01,{ }^{* * *} p<0.001$ 
Table A18. Party Institutionalization on coverage rates for sickness insurance (from SCIP)

\begin{tabular}{|c|c|c|c|c|c|c|c|c|c|}
\hline & Baseline & $\begin{array}{c}5 \text { year } \\
\text { lag }\end{array}$ & $\begin{array}{c}10 \text { year } \\
\text { lag }\end{array}$ & $\begin{array}{l}\text { (4) } \\
\text { Socio- } \\
\text { econ. } \\
\text { controls }\end{array}$ & $\begin{array}{c}\text { (5) } \\
\text { Work. } \\
\text { class } \\
\text { controls }\end{array}$ & $\begin{array}{c}\text { (6) } \\
\text { Instit. and } \\
\text { civil } \\
\text { society } \\
\text { controls }\end{array}$ & $\begin{array}{c}(7) \\
\text { First } \\
\text { component } \\
\text { PI }\end{array}$ & $\begin{array}{l}\text { Control } \\
\text { linkages }\end{array}$ & $\begin{array}{c}\text { (9) } \\
\text { Random } \\
\text { effects } \\
\text { model }\end{array}$ \\
\hline Partv Instit. & $1.27^{* * *}$ & $0.47^{* * *}$ & $0.24^{* *}$ & $3.95^{* * *}$ & $1.24^{* * *}$ & $1.38^{* * *}$ & $0.26^{* * *}$ & $1.08^{* * *}$ & 1.26 \\
\hline & $(5.40)$ & $(3.52)$ & (3.14) & $(5.06)$ & $(5.57)$ & $(5.00)$ & $(5.16)$ & $(4.28)$ & $(1.80)$ \\
\hline Polyarchy & $\begin{array}{l}-0.30^{*} \\
(-2.10)\end{array}$ & $\begin{array}{l}0.021 \\
(0.17)\end{array}$ & $\begin{array}{c}0.18 \\
(1.80)\end{array}$ & $\begin{array}{c}0.22 \\
(0.95)\end{array}$ & $\begin{array}{l}-0.095 \\
(-0.76)\end{array}$ & $\begin{array}{l}-0.38^{*} \\
(-2.41)\end{array}$ & $\begin{array}{l}-0.27 \\
(-1.93)\end{array}$ & $\begin{array}{l}-0.29^{*} \\
(-2.04)\end{array}$ & $\begin{array}{l}-0.33 \\
(-0.90)\end{array}$ \\
\hline Pop. (ln) & $\begin{array}{l}-0.041 \\
(-0.38)\end{array}$ & $\begin{array}{l}-0.016 \\
(-0.14)\end{array}$ & $\begin{array}{c}- \\
0.0024 \\
(-0.02)\end{array}$ & $\begin{array}{l}0.35^{*} \\
(2.47)\end{array}$ & $\begin{array}{l}0.046 \\
(0.43)\end{array}$ & $\begin{array}{l}-0.064 \\
(-0.68)\end{array}$ & $\begin{array}{l}-0.055 \\
(-0.51)\end{array}$ & $\begin{array}{l}-0.061 \\
(-0.58)\end{array}$ & $\begin{array}{l}-0.078 \\
(-0.85)\end{array}$ \\
\hline GDP pc (ln) & $\begin{array}{l}0.25^{* * *} \\
(4.94)\end{array}$ & $\begin{array}{l}0.24^{* * *} \\
(4.03)\end{array}$ & $\begin{array}{l}0.25^{* * *} \\
(4.48)\end{array}$ & $\begin{array}{l}0.19^{*} \\
(2.24)\end{array}$ & $\begin{array}{l}0.23^{* * *} \\
(5.02)\end{array}$ & $\begin{array}{l}0.26^{* * *} \\
(4.87)\end{array}$ & $\begin{array}{l}0.23^{* * *} \\
(4.37)\end{array}$ & $\begin{array}{l}0.24^{* * *} \\
(4.91)\end{array}$ & $\begin{array}{l}0.23^{*} \\
(2.25)\end{array}$ \\
\hline PR & $\begin{array}{l}-0.11^{*} \\
(-2.32)\end{array}$ & $\begin{array}{l}-0.020 \\
(-0.39)\end{array}$ & $\begin{array}{l}-0.070 \\
(-1.60)\end{array}$ & $\begin{array}{l}-0.048 \\
(-0.53)\end{array}$ & $\begin{array}{l}-0.15^{*} \\
(-2.55)\end{array}$ & $\begin{array}{l}0.025 \\
(0.49)\end{array}$ & $\begin{array}{l}-0.031 \\
(-0.66)\end{array}$ & $\begin{array}{l}-0.11^{*} \\
(-2.40)\end{array}$ & $\begin{array}{l}0.025 \\
(0.27)\end{array}$ \\
\hline Mixed & $\begin{array}{l}-0.025 \\
(-0.42)\end{array}$ & $\begin{array}{l}-0.038 \\
(-0.68)\end{array}$ & $\begin{array}{l}-0.068 \\
(-1.34)\end{array}$ & $\begin{array}{l}0.019 \\
(0.23)\end{array}$ & $\begin{array}{l}-0.048 \\
(-0.72)\end{array}$ & $\begin{array}{l}0.044 \\
(0.81)\end{array}$ & $\begin{array}{l}0.0095 \\
(0.16)\end{array}$ & $\begin{array}{l}-0.029 \\
(-0.52)\end{array}$ & $\begin{array}{l}0.062 \\
(0.65)\end{array}$ \\
\hline Urbaniz. & & & & $\begin{array}{c}-2.9 \mathrm{e}-09^{*} \\
(-2.05)\end{array}$ & & & & & \\
\hline Openness & & & & $\begin{array}{c}-0.00043 \\
(-0.19)\end{array}$ & & & & & \\
\hline Income ineq. & & & & $\begin{array}{c}-0.0016 \\
(-1.08)\end{array}$ & & & & & \\
\hline Fam. farms & & & & $\begin{array}{c}0.00081 \\
(0.44)\end{array}$ & & & & & \\
\hline Union dens. & & & & & $\begin{array}{c}0.0050^{* * *} \\
(4.57)\end{array}$ & & & & \\
\hline Left & & & & & $\begin{array}{l}0.027 \\
(1.43)\end{array}$ & & & & \\
\hline Corruption & & & & & & $\begin{array}{c}0.14 \\
(0.40)\end{array}$ & & & \\
\hline Imp. Admin. & & & & & & $\begin{array}{c}0.13^{* * *} \\
(4.16)\end{array}$ & & & \\
\hline Civil society & & & & & & $\begin{array}{l}-0.13 \\
(-1.13)\end{array}$ & & & \\
\hline Female parti. & & & & & & $\begin{array}{l}-0.48^{* *} \\
(-2.71)\end{array}$ & & & \\
\hline Party link. & & & & & & & & $\begin{array}{l}0.065 \\
(1.77)\end{array}$ & \\
\hline $\begin{array}{l}\text { Country } \\
\text { Dummies }\end{array}$ & Yes & Yes & Yes & Yes & Yes & Yes & Yes & Yes & No \\
\hline $\begin{array}{l}\text { Year } \\
\text { Dummies }\end{array}$ & Yes & Yes & Yes & Yes & Yes & Yes & Yes & Yes & Yes \\
\hline Observations & 267 & 265 & 265 & 186 & 254 & 267 & 267 & 267 & 267 \\
\hline
\end{tabular}


Table A19. Party institutionalization on social expenditure as share of GDP (from CPDS)

\begin{tabular}{|c|c|c|c|c|c|c|c|c|c|}
\hline & Baseline & $\begin{array}{c}(2) \\
5 \text { year } \\
\text { lag }\end{array}$ & $\begin{array}{c}(3) \\
10 \text { year } \\
\text { lag }\end{array}$ & $\begin{array}{c}\text { (4) } \\
\text { Socio- } \\
\text { econ. controls }\end{array}$ & $\begin{array}{c}(5) \\
\text { Work. } \\
\text { class } \\
\text { controls }\end{array}$ & $\begin{array}{c}\text { (6) } \\
\text { Instit. and } \\
\text { civil society } \\
\text { controls }\end{array}$ & $\begin{array}{c}(7) \\
\text { First } \\
\text { component } \\
\text { PI }\end{array}$ & $\begin{array}{c}\text { (8) } \\
\text { Control } \\
\text { linkages }\end{array}$ & $\begin{array}{c}(9) \\
\text { Random } \\
\text { effects } \\
\text { model }\end{array}$ \\
\hline Party Instit. & 3.69 & 1.91 & -0.079 & $6.96^{* *}$ & -1.81 & -3.63 & 0.49 & 2.92 & 3.49 \\
\hline & $(1.79)$ & $(1.88)$ & $(-0.11)$ & (2.91) & $(-0.49)$ & $(-1.37)$ & $(1.35)$ & $(1.47)$ & $(0.69)$ \\
\hline Polyarchy & $\begin{array}{c}1.61 \\
(1.36)\end{array}$ & $\begin{array}{l}2.55^{* *} \\
(2.88)\end{array}$ & $\begin{array}{l}3.12^{* * *} \\
(3.59)\end{array}$ & $\begin{array}{l}-0.57 \\
(-0.42)\end{array}$ & $\begin{array}{c}2.77 \\
(1.64)\end{array}$ & $\begin{array}{c}1.58 \\
(1.06)\end{array}$ & $\begin{array}{c}2.16 \\
(1.88)\end{array}$ & $\begin{array}{c}1.69 \\
(1.45)\end{array}$ & $\begin{array}{c}1.09 \\
(0.36)\end{array}$ \\
\hline Pop. (ln) & $\begin{array}{l}-4.43^{* * *} \\
(-5.39)\end{array}$ & $\begin{array}{c}- \\
5.32^{* * *} \\
(-5.10)\end{array}$ & $\begin{array}{c}-10.6^{* * *} \\
(- \\
10.01)\end{array}$ & $\begin{array}{l}-5.07^{* * *} \\
(-5.09)\end{array}$ & $\begin{array}{l}-10.2^{* * *} \\
(-9.48)\end{array}$ & $\begin{array}{l}-3.59^{* * *} \\
(-4.77)\end{array}$ & $\begin{array}{l}-4.40^{* * *} \\
(-5.32)\end{array}$ & $\begin{array}{l}-4.48^{* * *} \\
(-5.36)\end{array}$ & $\begin{array}{l}-0.88^{*} \\
(-1.97)\end{array}$ \\
\hline GDP pc (ln) & $\begin{array}{c}0.88 \\
(1.06)\end{array}$ & $\begin{array}{c}0.73 \\
(0.86)\end{array}$ & $\begin{array}{c}-0.32 \\
(-0.37)\end{array}$ & $\begin{array}{l}-0.66 \\
(-0.58)\end{array}$ & $\begin{array}{l}-0.66 \\
(-0.75)\end{array}$ & $\begin{array}{l}-0.75 \\
(-0.82)\end{array}$ & $\begin{array}{c}0.98 \\
(1.18)\end{array}$ & $\begin{array}{c}0.56 \\
(0.66)\end{array}$ & $\begin{array}{c}0.62 \\
(0.54)\end{array}$ \\
\hline PR & $\begin{array}{l}-1.29^{*} \\
(-2.17)\end{array}$ & $\begin{array}{l}-0.95 \\
(-1.60)\end{array}$ & $\begin{array}{l}-0.18 \\
(-0.30)\end{array}$ & $\begin{array}{l}-4.68^{* * *} \\
(-5.82)\end{array}$ & $\begin{array}{c}0.83 \\
(1.19)\end{array}$ & $\begin{array}{l}-2.81^{* * *} \\
(-4.63)\end{array}$ & $\begin{array}{l}-1.05 \\
(-1.83)\end{array}$ & $\begin{array}{l}-1.38^{*} \\
(-2.36)\end{array}$ & $\begin{array}{l}0.097 \\
(0.08)\end{array}$ \\
\hline Mixed & $\begin{array}{l}-1.70^{* *} \\
(-3.26)\end{array}$ & $\begin{array}{l}-1.55^{* *} \\
(-2.98)\end{array}$ & $\begin{array}{l}-1.23^{*} \\
(-2.41)\end{array}$ & $\begin{array}{c}-3.36^{* * *} \\
(-4.93)\end{array}$ & $\begin{array}{l}-0.39 \\
(-0.69)\end{array}$ & $\begin{array}{l}-2.49^{* * *} \\
(-4.25)\end{array}$ & $\begin{array}{l}-1.56^{* *} \\
(-3.02)\end{array}$ & $\begin{array}{c}-1.87^{* * *} \\
(-3.61)\end{array}$ & $\begin{array}{l}-0.57 \\
(-0.34)\end{array}$ \\
\hline Urbaniz. & & & & $\begin{array}{c}0.000000092^{* * *} \\
(5.02)\end{array}$ & & & & & \\
\hline Openness & & & & $\begin{array}{c}-0.14^{* * *} \\
(-5.81)\end{array}$ & & & & & \\
\hline Income ineq. & & & & $\begin{array}{l}-0.029^{*} \\
(-2.28)\end{array}$ & & & & & \\
\hline Fam. farms & & & & $\begin{array}{c}-0.0042 \\
(-0.26)\end{array}$ & & & & & \\
\hline Union dens. & & & & & $\begin{array}{c}0.039^{* * *} \\
(4.24)\end{array}$ & & & & \\
\hline Left & & & & & $\begin{array}{l}-0.42^{* *} \\
(-2.59)\end{array}$ & & & & \\
\hline Corruption & & & & & & $\begin{array}{l}-16.3^{* * *} \\
(-5.75)\end{array}$ & & & \\
\hline Imp. Admin. & & & & & & $\begin{array}{c}-1.08^{* * *} \\
(-5.01)\end{array}$ & & & \\
\hline Civil society & & & & & & $\begin{array}{l}-2.92^{* *} \\
(-3.23)\end{array}$ & & & \\
\hline Female parti. & & & & & & $\begin{array}{l}7.35^{* * *} \\
(4.21)\end{array}$ & & & \\
\hline Party link. & & & & & & & & $\begin{array}{c}0.44 \\
(1.83)\end{array}$ & \\
\hline $\begin{array}{l}\text { Country } \\
\text { Dummies }\end{array}$ & Yes & Yes & Yes & Yes & Yes & Yes & Yes & Yes & No \\
\hline $\begin{array}{l}\text { Year } \\
\text { Dummies }\end{array}$ & Yes & Yes & Yes & Yes & Yes & Yes & Yes & Yes & Yes \\
\hline Observations & 781 & 777 & 772 & 741 & 704 & 775 & 781 & 781 & 781 \\
\hline
\end{tabular}


Table A20. Party institutionalization on public goods (v2dlencmps from V-Dem)

\begin{tabular}{|c|c|c|c|c|c|c|c|c|c|}
\hline & Baseline & $\begin{array}{c}(2) \\
5 \text { year } \\
\text { lag }\end{array}$ & $\begin{array}{c}(3) \\
10 \text { year } \\
\text { lag }\end{array}$ & $\begin{array}{c}(4) \\
\text { Socio- } \\
\text { econ. } \\
\text { controls }\end{array}$ & $\begin{array}{c}(5) \\
\text { Work. } \\
\text { class } \\
\text { controls }\end{array}$ & $\begin{array}{c}(6) \\
\text { Instit. and } \\
\text { civil society } \\
\text { controls }\end{array}$ & $\begin{array}{c}(7) \\
\text { First } \\
\text { component } \\
\text { PI }\end{array}$ & $\begin{array}{c}\text { (8) } \\
\text { Control } \\
\text { linkages }\end{array}$ & $\begin{array}{c}(9) \\
\text { Random } \\
\text { effects } \\
\text { model }\end{array}$ \\
\hline Party Instit. & $\begin{array}{l}1.26^{* * *} \\
(16.51)\end{array}$ & $\begin{array}{c}0.59^{* * * *} \\
(8.10)\end{array}$ & $\begin{array}{c}0.12 \\
(1.65)\end{array}$ & $\begin{array}{l}1.10^{* * *} \\
(11.90)\end{array}$ & $\begin{array}{l}1.20^{* * *} \\
(6.63)\end{array}$ & $\begin{array}{l}0.95^{* * *} \\
(13.62)\end{array}$ & $\begin{array}{l}0.33^{* * *} \\
(21.77)\end{array}$ & $\begin{array}{c}0.59^{* * *} \\
(7.42)\end{array}$ & $\begin{array}{l}1.26^{* * *} \\
(3.36)\end{array}$ \\
\hline Polyarchy & $\begin{array}{l}0.57^{* * *} \\
(8.96)\end{array}$ & $\begin{array}{l}0.94^{* * *} \\
(15.07)\end{array}$ & $\begin{array}{c}1.08^{* * *} \\
(17.24)\end{array}$ & $\begin{array}{l}0.86^{* * *} \\
(12.34)\end{array}$ & $\begin{array}{l}1.40^{* * *} \\
(9.78)\end{array}$ & $\begin{array}{l}-0.27^{* *} \\
(-2.86)\end{array}$ & $\begin{array}{l}0.56^{* * *} \\
(8.61)\end{array}$ & $\begin{array}{c}0.49^{* * *} \\
(7.74)\end{array}$ & $\begin{array}{l}0.61^{*} \\
(2.08)\end{array}$ \\
\hline Population & $\begin{array}{l}0.16^{* * * *} \\
(4.05)\end{array}$ & $\begin{array}{l}0.21^{* * * *} \\
(4.84)\end{array}$ & $\begin{array}{c}0.26^{* * *} \\
(5.71)\end{array}$ & $\begin{array}{l}0.28^{* * *} \\
(4.16)\end{array}$ & $\begin{array}{c}-0.43^{* * *} \\
(-4.18)\end{array}$ & $\begin{array}{l}0.35^{* * *} \\
(8.64)\end{array}$ & $\begin{array}{l}0.19^{* * *} \\
(4.79)\end{array}$ & $\begin{array}{c}0.17^{\text {*** }} \\
(4.41)\end{array}$ & $\begin{array}{c}0.11 \\
(0.93)\end{array}$ \\
\hline GDP & $\begin{array}{c}0.081^{* *} \\
(2.59)\end{array}$ & $\begin{array}{l}0.050 \\
(1.54)\end{array}$ & $\begin{array}{l}0.073^{*} \\
(2.18)\end{array}$ & $\begin{array}{l}0.028 \\
(0.66)\end{array}$ & $\begin{array}{c}-0.30^{* * *} \\
(-3.69)\end{array}$ & $\begin{array}{l}0.045 \\
(1.54)\end{array}$ & $\begin{array}{l}0.038 \\
(1.24)\end{array}$ & $\begin{array}{l}0.013 \\
(0.45)\end{array}$ & $\begin{array}{l}0.084 \\
(0.70)\end{array}$ \\
\hline PR & $\begin{array}{l}-0.050 \\
(-1.44)\end{array}$ & $\begin{array}{l}-0.039 \\
(-1.08)\end{array}$ & $\begin{array}{l}-0.039 \\
(-1.03)\end{array}$ & $\begin{array}{l}-0.11^{*} \\
(-2.47)\end{array}$ & $\begin{array}{l}0.089 \\
(1.46)\end{array}$ & $\begin{array}{l}-0.052 \\
(-1.70)\end{array}$ & $\begin{array}{l}-0.074^{*} \\
(-2.16)\end{array}$ & $\begin{array}{c}-0.12^{* * *} \\
(-3.55)\end{array}$ & $\begin{array}{l}-0.045 \\
(-0.32)\end{array}$ \\
\hline Mixed & $\begin{array}{l}-0.27^{* * *} \\
(-6.93)\end{array}$ & $\begin{array}{l}-0.24^{* * *} \\
(-5.95)\end{array}$ & $\begin{array}{l}-0.26^{* * *} \\
(-6.16)\end{array}$ & $\begin{array}{c}-0.20^{* * *} \\
(-4.77)\end{array}$ & $\begin{array}{l}-0.16^{* *} \\
(-2.68)\end{array}$ & $\begin{array}{c}-0.22^{* * *} \\
(-6.50)\end{array}$ & $\begin{array}{l}-0.30^{* * *} \\
(-7.79)\end{array}$ & $\begin{array}{l}-0.29^{* * *} \\
(-7.64)\end{array}$ & $\begin{array}{c}-0.27 \\
(-1.70)\end{array}$ \\
\hline Urbaniz & & & & $\begin{array}{l}-3.6 \mathrm{e}- \\
09^{* * *} \\
(-6.16)\end{array}$ & & & & & \\
\hline Openness & & & & $\begin{array}{c}0.00080 \\
(0.42)\end{array}$ & & & & & \\
\hline Income ineq. & & & & $\begin{array}{c}-0.0031^{*} \\
(-2.29)\end{array}$ & & & & & \\
\hline Fam. farms & & & & $\begin{array}{c}0.0071^{* * *} \\
(5.66)\end{array}$ & & & & & \\
\hline Union Dens. & & & & & $\begin{array}{c}0.00068 \\
(0.63)\end{array}$ & & & & \\
\hline Left & & & & & $\begin{array}{l}0.18^{* * *} \\
(5.61)\end{array}$ & & & & \\
\hline Inter-st. war & & & & & & $\begin{array}{c}-0.094^{* *} \\
(-2.87)\end{array}$ & & & \\
\hline Civil war & & & & & & $\begin{array}{l}-0.16^{* * *} \\
(-4.65)\end{array}$ & & & \\
\hline Corruption & & & & & & $\begin{array}{l}-1.89^{* * *} \\
(-17.69)\end{array}$ & & & \\
\hline Imp. Admin. & & & & & & $\begin{array}{c}0.081^{* * *} \\
(4.95)\end{array}$ & & & \\
\hline Female parti. & & & & & & $\begin{array}{l}1.30^{* * *} \\
(18.75)\end{array}$ & & & \\
\hline Civil society & & & & & & $\begin{array}{l}-0.058 \\
(-0.72)\end{array}$ & & & \\
\hline Party linkages & & & & & & & & $\begin{array}{c}0.33^{* * *} \\
(20.27)\end{array}$ & \\
\hline $\begin{array}{l}\text { Country } \\
\text { Dummies }\end{array}$ & Yes & Yes & Yes & Yes & Yes & Yes & Yes & Yes & No \\
\hline $\begin{array}{l}\text { Year } \\
\text { Dummies }\end{array}$ & Yes & Yes & Yes & Yes & Yes & Yes & Yes & Yes & Yes \\
\hline Observations & 7137 & 6975 & 6732 & 4208 & 1635 & 6116 & 7093 & 7125 & 7137 \\
\hline
\end{tabular}


Table A21. Party institutionalization on coverage of major risks (Encompassingness, from SPAW) including one control at a time

\begin{tabular}{|c|c|c|c|c|c|c|c|c|c|c|c|c|c|}
\hline & $(1)$ & (2) & (3) & (4) & (5) & (6) & (7) & (8) & (9) & (10) & (11) & (12) & (13) \\
\hline Party Instit. & $\begin{array}{l}0.42^{* * *} \\
(5.85)\end{array}$ & $\begin{array}{l}0.43^{* * *} \\
(5.83)\end{array}$ & $\begin{array}{l}0.42^{* * *} \\
(5.91)\end{array}$ & $\begin{array}{l}0.16^{*} \\
(2.23)\end{array}$ & $\begin{array}{l}0.44^{* * *} \\
(6.05)\end{array}$ & $\begin{array}{l}1.20^{* * *} \\
(7.25)\end{array}$ & $\begin{array}{l}0.67^{* * *} \\
(5.28)\end{array}$ & $\begin{array}{l}0.41^{* * *} \\
(5.63)\end{array}$ & $\begin{array}{l}0.45^{* * *} \\
(6.28)\end{array}$ & $\begin{array}{l}0.42^{* * *} \\
(5.69)\end{array}$ & $\begin{array}{l}0.39^{* * *} \\
(5.50)\end{array}$ & $\begin{array}{l}0.47^{* * *} \\
(6.19)\end{array}$ & $\begin{array}{l}0.41^{* * *} \\
(5.68)\end{array}$ \\
\hline Polyarchy & $\begin{array}{l}-0.44^{* * *} \\
(-6.30)\end{array}$ & $\begin{array}{l}-0.44^{* * *} \\
(-6.24)\end{array}$ & $\begin{array}{c}-0.42^{* * *} \\
(-6.03)\end{array}$ & $\begin{array}{l}-0.30^{* * *} \\
(-4.74)\end{array}$ & $\begin{array}{c}-0.44^{* * *} \\
(-6.28)\end{array}$ & $\begin{array}{l}-0.35^{* *} \\
(-2.81)\end{array}$ & $\begin{array}{c}-0.71^{* * *} \\
(-7.06)\end{array}$ & $\begin{array}{l}-0.44^{* * *} \\
(-6.11)\end{array}$ & $\begin{array}{l}-0.46^{* * *} \\
(-6.50)\end{array}$ & $\begin{array}{l}-0.44^{* * *} \\
(-5.99)\end{array}$ & $\begin{array}{c}-0.66^{* * *} \\
(-8.14)\end{array}$ & $\begin{array}{l}-0.30^{* * *} \\
(-3.77)\end{array}$ & $\begin{array}{l}-0.52^{* * *} \\
(-5.56)\end{array}$ \\
\hline Pop. & $\begin{array}{l}1.17^{* * *} \\
(26.99)\end{array}$ & $\begin{array}{l}1.22^{* * *} \\
(27.39)\end{array}$ & $\begin{array}{l}1.20^{* * *} \\
(27.20)\end{array}$ & $\begin{array}{l}0.60^{* * *} \\
(11.55)\end{array}$ & $\begin{array}{l}1.17^{* * *} \\
(26.48)\end{array}$ & $\begin{array}{l}1.00^{* * *} \\
(11.53)\end{array}$ & $\begin{array}{l}1.18^{* * *} \\
(20.32)\end{array}$ & $\begin{array}{l}1.23^{* * *} \\
(27.42)\end{array}$ & $\begin{array}{l}1.19^{* * *} \\
(27.49)\end{array}$ & $\begin{array}{l}1.17^{* * * *} \\
(26.98)\end{array}$ & $\begin{array}{l}1.19^{* * *} \\
(27.23)\end{array}$ & $\begin{array}{l}1.14^{* * *} \\
(25.54)\end{array}$ & $\begin{array}{l}1.16^{* * *} \\
(27.00)\end{array}$ \\
\hline GDP & $\begin{array}{l}0.18^{* * *} \\
(4.98)\end{array}$ & $\begin{array}{l}0.23^{* * *} \\
(6.02)\end{array}$ & $\begin{array}{l}0.23^{* * *} \\
(6.25)\end{array}$ & $\begin{array}{l}0.32^{* * *} \\
(7.17)\end{array}$ & $\begin{array}{l}0.18^{* * *} \\
(4.67)\end{array}$ & $\begin{array}{c}0.11 \\
(1.66)\end{array}$ & $\begin{array}{c}-0.37^{* * *} \\
(-5.40)\end{array}$ & $\begin{array}{l}0.21^{* * *} \\
(5.30)\end{array}$ & $\begin{array}{l}0.20^{* * *} \\
(5.47)\end{array}$ & $\begin{array}{l}0.18^{* * *} \\
(4.94)\end{array}$ & $\begin{array}{l}0.16^{* * *} \\
(4.33)\end{array}$ & $\begin{array}{l}0.12^{* *} \\
(2.96)\end{array}$ & $\begin{array}{l}0.18^{* * *} \\
(5.00)\end{array}$ \\
\hline PR & $\begin{array}{l}0.55^{* * *} \\
(16.22)\end{array}$ & $\begin{array}{l}0.54^{* * *} \\
(15.64)\end{array}$ & $\begin{array}{l}0.52^{* * *} \\
(15.52)\end{array}$ & $\begin{array}{l}0.23^{* * *} \\
(5.51)\end{array}$ & $\begin{array}{l}0.57^{* * *} \\
(16.38)\end{array}$ & $\begin{array}{l}0.45^{* * *} \\
(7.00)\end{array}$ & $\begin{array}{l}0.75^{* * *} \\
(14.32)\end{array}$ & $\begin{array}{l}0.55^{* * *} \\
(16.12)\end{array}$ & $\begin{array}{l}0.55^{* * *} \\
(16.24)\end{array}$ & $\begin{array}{l}0.55^{* * *} \\
(16.25)\end{array}$ & $\begin{array}{l}0.56^{* * *} \\
(16.55)\end{array}$ & $\begin{array}{l}0.52^{* * *} \\
(13.47)\end{array}$ & $\begin{array}{l}0.55^{* * *} \\
(15.63)\end{array}$ \\
\hline Mixed & $\begin{array}{l}0.52^{* * *} \\
(11.37)\end{array}$ & $\begin{array}{l}0.52^{* * *} \\
(11.41)\end{array}$ & $\begin{array}{l}0.49^{* * *} \\
(11.35)\end{array}$ & $\begin{array}{l}0.21^{* * *} \\
(3.55)\end{array}$ & $\begin{array}{l}0.52^{* * *} \\
(11.12)\end{array}$ & $\begin{array}{c}0.42^{* * *} \\
(6.36)\end{array}$ & $\begin{array}{c}0.46^{* * *} \\
(7.15)\end{array}$ & $\begin{array}{l}0.54^{* * *} \\
(11.41)\end{array}$ & $\begin{array}{l}0.50^{* * *} \\
(11.46)\end{array}$ & $\begin{array}{l}0.52^{* * *} \\
(11.41)\end{array}$ & $\begin{array}{l}0.53^{* * *} \\
(11.47)\end{array}$ & $\begin{array}{l}0.45^{* * *} \\
(9.24)\end{array}$ & $\begin{array}{l}0.52^{* * *} \\
(11.23)\end{array}$ \\
\hline Urban & & $\begin{array}{l}-3.7^{* * *} \\
(-6.61)\end{array}$ & & & & & & & & & & & \\
\hline Openness & & & $\begin{array}{c}-0.0046^{*} \\
(-2.28)\end{array}$ & & & & & & & & & & \\
\hline Inc, ineq. & & & & $\begin{array}{c}0.014^{* * *} \\
(9.08)\end{array}$ & & & & & & & & & \\
\hline Fam. farms & & & & & $\begin{array}{c}0.0013 \\
(1.40)\end{array}$ & & & & & & & & \\
\hline Union den. & & & & & & $\begin{array}{c}0.0048^{* * *} \\
(5.04)\end{array}$ & & & & & & & \\
\hline Left executive & & & & & & & $\begin{array}{c}-0.092^{* *} \\
(-2.73)\end{array}$ & & & & & & \\
\hline Inter-state war. & & & & & & & & $\begin{array}{c}-0.093^{*} \\
(-2.33)\end{array}$ & & & & & \\
\hline Civil war & & & & & & & & & $\begin{array}{l}-0.088^{*} \\
(-2.21)\end{array}$ & & & & \\
\hline Corruption & & & & & & & & & & $\begin{array}{c}0.0028 \\
(0.03)\end{array}$ & & & \\
\hline Imp. Admin. & & & & & & & & & & & $\begin{array}{c}0.078^{* * *} \\
(5.13)\end{array}$ & & \\
\hline Women pol. & & & & & & & & & & & & $\begin{array}{c}-0.72^{* * *} \\
(-8.10)\end{array}$ & \\
\hline Civil society & & & & & & & & & & & & & $\begin{array}{c}0.11 \\
(1.31)\end{array}$ \\
\hline Country FE & Yes & Yes & Yes & Yes & Yes & Yes & Yes & Yes & Yes & Yes & Yes & Yes & Yes \\
\hline Year FE & Yes & Yes & Yes & Yes & Yes & Yes & Yes & Yes & Yes & Yes & Yes & Yes & Yes \\
\hline Observations & 6154 & 6003 & 6052 & 3860 & 6051 & 1832 & 2449 & 5852 & 6140 & 6154 & 6154 & 5553 & 6154 \\
\hline
\end{tabular}


Table A22. Party institutionalization and universalism (v2dlunivl, from V-Dem) including one control at a time.

\begin{tabular}{|c|c|c|c|c|c|c|c|c|c|c|c|c|c|}
\hline & (1) & (2) & (3) & (4) & (5) & (6) & (7) & (8) & (9) & (10) & (11) & $(12)$ & (13) \\
\hline Party Instit. & $\begin{array}{l}1.30^{* * *} \\
(16.23)\end{array}$ & $\begin{array}{l}1.29^{* * *} \\
(15.95)\end{array}$ & $\begin{array}{l}1.32^{* * *} \\
(16.28)\end{array}$ & $\begin{array}{l}1.24^{* * *} \\
(11.66)\end{array}$ & $\begin{array}{l}1.25^{* * *} \\
(15.32)\end{array}$ & $\begin{array}{l}1.51^{* * *} \\
(7.50)\end{array}$ & $\begin{array}{c}1.35^{* * *} \\
(11.07)\end{array}$ & $\begin{array}{l}1.32^{* * *} \\
(15.95)\end{array}$ & $\begin{array}{l}1.30^{* * *} \\
(16.28)\end{array}$ & $\begin{array}{l}1.12^{* * *} \\
(14.76)\end{array}$ & $\begin{array}{l}1.25^{* * *} \\
(16.19)\end{array}$ & $\begin{array}{l}1.33^{* * *} \\
(17.84)\end{array}$ & $\begin{array}{l}1.31^{* * * *} \\
(16.55)\end{array}$ \\
\hline Polyarchy & $\begin{array}{l}0.35^{* * *} \\
(5.42)\end{array}$ & $\begin{array}{l}0.40^{* * *} \\
(6.18)\end{array}$ & $\begin{array}{l}0.33^{* * *} \\
(5.03)\end{array}$ & $\begin{array}{l}0.53^{* * *} \\
(7.64)\end{array}$ & $\begin{array}{l}0.43^{* * *} \\
(6.65)\end{array}$ & $\begin{array}{l}1.24^{* * *} \\
(9.38)\end{array}$ & $\begin{array}{c}1.37^{* * *} \\
(16.79)\end{array}$ & $\begin{array}{l}0.37^{* * *} \\
(5.57)\end{array}$ & $\begin{array}{l}0.33^{* * *} \\
(5.10)\end{array}$ & $\begin{array}{l}0.049 \\
(0.74)\end{array}$ & $\begin{array}{l}-0.22^{* *} \\
(-2.84)\end{array}$ & $\begin{array}{l}-0.074 \\
(-1.07)\end{array}$ & $\begin{array}{c}0.43^{* * *} \\
(5.08)\end{array}$ \\
\hline Pop. & $\begin{array}{l}0.10^{*} \\
(2.53)\end{array}$ & $\begin{array}{l}0.12^{* *} \\
(2.92)\end{array}$ & $\begin{array}{l}0.11^{* *} \\
(2.63)\end{array}$ & $\begin{array}{l}0.67^{* * *} \\
(11.65)\end{array}$ & $\begin{array}{l}0.090^{*} \\
(2.16)\end{array}$ & $\begin{array}{c}-0.31^{* * *} \\
(-4.32)\end{array}$ & $\begin{array}{l}-0.66^{* * *} \\
(-12.99)\end{array}$ & $\begin{array}{l}0.11^{* *} \\
(2.59)\end{array}$ & $\begin{array}{l}0.11^{*} \\
(2.57)\end{array}$ & $\begin{array}{l}0.11^{* *} \\
(2.76)\end{array}$ & $\begin{array}{l}0.14^{* * *} \\
(3.30)\end{array}$ & $\begin{array}{l}0.25^{* * *} \\
(6.71)\end{array}$ & $\begin{array}{l}0.11^{* *} \\
(2.67)\end{array}$ \\
\hline GDP & $\begin{array}{l}0.28^{* * *} \\
(9.74)\end{array}$ & $\begin{array}{l}0.30^{* * *} \\
(10.46)\end{array}$ & $\begin{array}{c}0.30^{* * *} \\
(9.76)\end{array}$ & $\begin{array}{l}0.38^{* * *} \\
(12.71)\end{array}$ & $\begin{array}{l}0.30^{* * *} \\
(9.66)\end{array}$ & $\begin{array}{l}0.64^{* * *} \\
(11.19)\end{array}$ & $\begin{array}{l}0.31^{* * *} \\
(5.67)\end{array}$ & $\begin{array}{l}0.29^{* * *} \\
(9.43)\end{array}$ & $\begin{array}{c}0.27^{* * *} \\
(9.18)\end{array}$ & $\begin{array}{c}0.23^{* * *} \\
(7.96)\end{array}$ & $\begin{array}{c}0.21^{* * *} \\
(7.40)\end{array}$ & $\begin{array}{c}0.29^{* * *} \\
(9.97)\end{array}$ & $\begin{array}{c}0.28^{* * *} \\
(9.67)\end{array}$ \\
\hline PR & $\begin{array}{l}0.10^{* *} \\
(2.65)\end{array}$ & $\begin{array}{l}0.094^{*} \\
(2.47)\end{array}$ & $\begin{array}{l}0.075 \\
(1.93)\end{array}$ & $\begin{array}{l}-0.16^{* * *} \\
(-3.34)\end{array}$ & $\begin{array}{l}0.068 \\
(1.78)\end{array}$ & $\begin{array}{l}0.53^{* * *} \\
(9.21)\end{array}$ & $\begin{array}{l}0.48^{* * *} \\
(10.61)\end{array}$ & $\begin{array}{l}0.093^{*} \\
(2.43)\end{array}$ & $\begin{array}{l}0.10^{* *} \\
(2.76)\end{array}$ & $\begin{array}{l}0.10^{* *} \\
(2.86)\end{array}$ & $\begin{array}{l}0.12^{* *} \\
(3.19)\end{array}$ & $\begin{array}{l}0.11^{* *} \\
(3.02)\end{array}$ & $\begin{array}{l}0.11^{* *} \\
(2.81)\end{array}$ \\
\hline Mixed & $\begin{array}{l}-0.14^{* * *} \\
(-3.80)\end{array}$ & $\begin{array}{c}-0.14^{* * *} \\
(-3.78)\end{array}$ & $\begin{array}{l}-0.16^{* * *} \\
(-4.02)\end{array}$ & $\begin{array}{l}-0.22^{* * *} \\
(-5.28)\end{array}$ & $\begin{array}{l}-0.15^{* * *} \\
(-4.01)\end{array}$ & $\begin{array}{l}0.15^{*} \\
(2.20)\end{array}$ & $\begin{array}{l}0.41^{* * *} \\
(8.00)\end{array}$ & $\begin{array}{c}-0.15^{* * *} \\
(-3.83)\end{array}$ & $\begin{array}{c}-0.14^{* * *} \\
(-3.78)\end{array}$ & $\begin{array}{l}-0.10^{* *} \\
(-2.89)\end{array}$ & $\begin{array}{c}-0.14^{* * *} \\
(-3.53)\end{array}$ & $\begin{array}{l}-0.070^{*} \\
(-2.00)\end{array}$ & $\begin{array}{l}-0.14^{* * *} \\
(-3.66)\end{array}$ \\
\hline Urban & & $\begin{array}{c}-2.9 \mathrm{e}-09^{* * *} \\
(-6.35)\end{array}$ & & & & & & & & & & & \\
\hline Openness & & & $\begin{array}{c}-0.0029^{*} \\
(-1.97)\end{array}$ & & & & & & & & & & \\
\hline Inc, ineq. & & & & $\begin{array}{c}-0.0037^{* *} \\
(-2.67)\end{array}$ & & & & & & & & & \\
\hline Fam. farms & & & & & $\begin{array}{c}0.0029^{* * *} \\
(3.48)\end{array}$ & & & & & & & & \\
\hline Union den. & & & & & & $\begin{array}{c}0.0085^{* * *} \\
(8.18)\end{array}$ & & & & & & & \\
\hline Left executive & & & & & & & $\begin{array}{l}0.13^{* * *} \\
(4.97)\end{array}$ & & & & & & \\
\hline Inter-state war. & & & & & & & & $\begin{array}{l}-0.040 \\
(-1.13)\end{array}$ & & & & & \\
\hline Civil war & & & & & & & & & $\begin{array}{c}-0.21^{\text {*** }} \\
(-6.02)\end{array}$ & & & & \\
\hline Corruption & & & & & & & & & & $\begin{array}{l}-1.53^{* * *} \\
(-15.34)\end{array}$ & & & \\
\hline Imp. Admin. & & & & & & & & & & & $\begin{array}{l}0.21^{\text {*** }} \\
(14.80)\end{array}$ & & \\
\hline Women pol. & & & & & & & & & & & & $\begin{array}{l}2.02^{* * *} \\
(27.29)\end{array}$ & \\
\hline Civil society & & & & & & & & & & & & & $\begin{array}{c}-0.11 \\
(-1.27)\end{array}$ \\
\hline Country FE & Yes & Yes & Yes & Yes & Yes & Yes & Yes & Yes & Yes & Yes & Yes & Yes & Yes \\
\hline Year FE & Yes & Yes & Yes & Yes & Yes & Yes & Yes & Yes & Yes & Yes & Yes & Yes & Yes \\
\hline Observations & 7137 & 6986 & 6987 & 4447 & 6981 & 1994 & 2604 & 6779 & 7122 & 7137 & 7137 & 6435 & 7137 \\
\hline
\end{tabular}


Table A23. Party institutionalization and universalism (Universalism Index; SPAW) including one control at a time

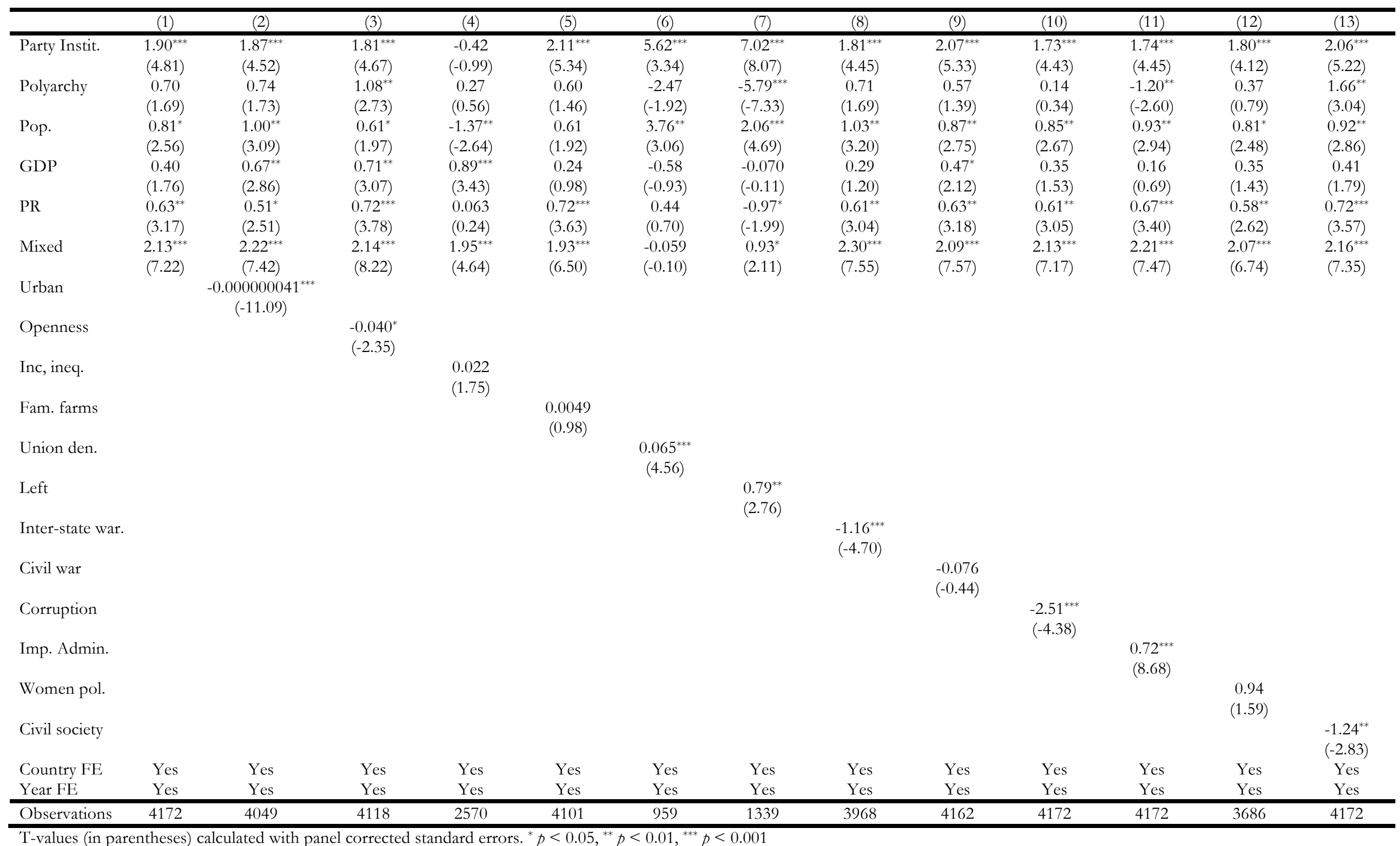


Table A24. Party institutionalization and replacement rates for sickness insurance (from SCIP) including one control at a time

\begin{tabular}{|c|c|c|c|c|c|c|c|c|c|c|c|}
\hline & $(1)$ & $(2)$ & (3) & (4) & (5) & (6) & $(7)$ & (8) & (9) & (10) & (11) \\
\hline Party Instit & $\begin{array}{l}1.63^{* * *} \\
(8.03)\end{array}$ & $\begin{array}{l}1.39^{* * *} \\
(6.87)\end{array}$ & $\begin{array}{l}1.28^{* * *} \\
(5.95)\end{array}$ & $\begin{array}{l}1.46^{*} \\
(2.18)\end{array}$ & $\begin{array}{l}1.67^{* * *} \\
(8.12)\end{array}$ & $\begin{array}{l}1.61^{* * *} \\
(8.39)\end{array}$ & $\begin{array}{l}1.62^{* * *} \\
(8.06)\end{array}$ & $\begin{array}{l}1.44^{* * *} \\
(5.98)\end{array}$ & $\begin{array}{l}1.55^{* * *} \\
(7.85)\end{array}$ & $\begin{array}{l}1.63^{* * *} \\
(8.04)\end{array}$ & $\begin{array}{l}2.01^{* * *} \\
(8.18)\end{array}$ \\
\hline Polyarchy & $\begin{array}{l}-0.54^{* * *} \\
(-3.86)\end{array}$ & $\begin{array}{l}-0.34^{*} \\
(-2.40)\end{array}$ & $\begin{array}{l}-0.20 \\
(-1.26)\end{array}$ & $\begin{array}{c}-0.67^{* * *} \\
(-3.50)\end{array}$ & $\begin{array}{c}-0.59^{* * *} \\
(-4.07)\end{array}$ & $\begin{array}{l}-0.33^{*} \\
(-2.57)\end{array}$ & $\begin{array}{c}-0.53^{* * *} \\
(-3.83)\end{array}$ & $\begin{array}{c}-0.62^{* * *} \\
(-4.19)\end{array}$ & $\begin{array}{l}-0.62^{* * *} \\
(-4.05)\end{array}$ & $\begin{array}{c}-0.50^{* * *} \\
(-3.39)\end{array}$ & $\begin{array}{l}-0.41^{* *} \\
(-2.89)\end{array}$ \\
\hline Pop. & $\begin{array}{l}-0.19^{*} \\
(-2.31)\end{array}$ & $\begin{array}{l}-0.050 \\
-0.60)\end{array}$ & $\begin{array}{l}-0.087 \\
(-1.05)\end{array}$ & $\begin{array}{l}-0.34^{*} \\
(-2.16)\end{array}$ & $\begin{array}{l}-0.11 \\
(-1.07)\end{array}$ & $\begin{array}{l}-0.11 \\
(-1.29)\end{array}$ & $\begin{array}{l}-0.19^{*} \\
(-2.30)\end{array}$ & $\begin{array}{l}-0.23^{* *} \\
(-2.72)\end{array}$ & $\begin{array}{l}-0.19^{*} \\
(-2.40)\end{array}$ & $\begin{array}{l}-0.17^{*} \\
(-2.14)\end{array}$ & $\begin{array}{l}-0.24^{* *} \\
(-2.83)\end{array}$ \\
\hline GDP & $\begin{array}{l}0.018 \\
(0.37)\end{array}$ & $\begin{array}{l}0.056 \\
(1.20)\end{array}$ & $\begin{array}{l}0.100 \\
(1.61)\end{array}$ & $\begin{array}{c}0.0011 \\
(0.01)\end{array}$ & $\begin{array}{c}0.0071 \\
(0.14)\end{array}$ & $\begin{array}{l}-0.033 \\
(-0.70)\end{array}$ & $\begin{array}{l}0.016 \\
(0.32)\end{array}$ & $\begin{array}{l}0.044 \\
(0.82)\end{array}$ & $\begin{array}{l}0.032 \\
(0.62)\end{array}$ & $\begin{array}{c}-0.0026 \\
(-0.05)\end{array}$ & $\begin{array}{l}0.012 \\
(0.24)\end{array}$ \\
\hline PR & $\begin{array}{l}0.071 \\
(1.26)\end{array}$ & $\begin{array}{l}0.052 \\
(0.90)\end{array}$ & $\begin{array}{l}0.023 \\
(0.37)\end{array}$ & $\begin{array}{l}-0.20 \\
(-1.77)\end{array}$ & $\begin{array}{l}0.081 \\
(1.40)\end{array}$ & $\begin{array}{l}0.035 \\
(0.65)\end{array}$ & $\begin{array}{l}0.066 \\
(1.15)\end{array}$ & $\begin{array}{l}0.088 \\
(1.38)\end{array}$ & $\begin{array}{c}0.11 \\
(1.73)\end{array}$ & $\begin{array}{l}0.093 \\
(1.49)\end{array}$ & $\begin{array}{l}0.069 \\
(1.18)\end{array}$ \\
\hline Mixed & $\begin{array}{c}0.12 \\
(1.95)\end{array}$ & $\begin{array}{l}0.096 \\
(1.47)\end{array}$ & $\begin{array}{l}0.081 \\
(1.15)\end{array}$ & $\begin{array}{c}-0.12 \\
(-1.17)\end{array}$ & $\begin{array}{l}0.13^{*} \\
(2.00)\end{array}$ & $\begin{array}{l}0.080 \\
(1.35)\end{array}$ & $\begin{array}{c}0.12 \\
(1.92)\end{array}$ & $\begin{array}{l}0.15^{*} \\
(2.16)\end{array}$ & $\begin{array}{l}0.14^{*} \\
(2.14)\end{array}$ & $\begin{array}{c}0.14^{*} \\
(2.07)\end{array}$ & $\begin{array}{c}0.12 \\
(1.88)\end{array}$ \\
\hline Urban & & $\begin{array}{c}-3.4 \mathrm{e}-09^{* * *} \\
(-6.50)\end{array}$ & & & & & & & & & \\
\hline Openness & & & $\begin{array}{c}-0.0082^{* * *} \\
(-5.76)\end{array}$ & & & & & & & & \\
\hline Inc, ineq. & & & & $\begin{array}{c}-0.0012 \\
(-0.63)\end{array}$ & & & & & & & \\
\hline Fam. farms & & & & & $\begin{array}{c}0.0021 \\
(1.48)\end{array}$ & & & & & & \\
\hline Union den. & & & & & & $\begin{array}{c}0.0054^{* * *} \\
(6.36)\end{array}$ & & & & & \\
\hline Left & & & & & & & $\begin{array}{l}0.019 \\
(0.88)\end{array}$ & & & & \\
\hline Corruption & & & & & & & & $\begin{array}{c}-0.75 \\
(-1.87)\end{array}$ & & & \\
\hline Imp. Admin. & & & & & & & & & $\begin{array}{l}0.042 \\
(1.56)\end{array}$ & & \\
\hline Women pol. & & & & & & & & & & $\begin{array}{l}-0.12 \\
(-1.06)\end{array}$ & \\
\hline Civil society & & & & & & & & & & & $\begin{array}{c}-0.60^{* * *} \\
(-3.38)\end{array}$ \\
\hline Country FE & Yes & Yes & Yes & Yes & Yes & Yes & Yes & Yes & Yes & Yes & Yes \\
\hline Year FE & Yes & Yes & Yes & Yes & Yes & Yes & Yes & Yes & Yes & Yes & Yes \\
\hline Observations & 263 & 263 & 259 & 184 & 263 & 250 & 263 & 263 & 263 & 263 & 263 \\
\hline
\end{tabular}


Table A25. Party institutionalization and coverage rates for sickness insurance (from SCIP) including one control at a time

\begin{tabular}{|c|c|c|c|c|c|c|c|c|c|c|c|}
\hline & (1) & (2) & (3) & (4) & (5) & (6) & (7) & (8) & (9) & $(10)$ & $(11)$ \\
\hline Party Instit. & $\begin{array}{l}1.27^{* * *} \\
(5.40)\end{array}$ & $\begin{array}{l}1.07^{* * *} \\
(4.53)\end{array}$ & $\begin{array}{l}1.06^{* * *} \\
(4.21)\end{array}$ & $\begin{array}{l}3.64^{* * *} \\
(4.77)\end{array}$ & $\begin{array}{l}1.40^{* * *} \\
(5.82)\end{array}$ & $\begin{array}{l}1.25^{* * *} \\
(5.56)\end{array}$ & $\begin{array}{l}1.27^{* * *} \\
(5.42)\end{array}$ & $\begin{array}{l}1.26^{* * *} \\
(4.90)\end{array}$ & $\begin{array}{l}1.04^{* * *} \\
(4.88)\end{array}$ & $\begin{array}{l}1.28^{* * *} \\
(5.43)\end{array}$ & $\begin{array}{l}1.62^{* * *} \\
(5.70)\end{array}$ \\
\hline Polyarchy & $\begin{array}{l}-0.30^{*} \\
(-2.10)\end{array}$ & $\begin{array}{l}-0.13 \\
(-0.87)\end{array}$ & $\begin{array}{l}-0.12 \\
(-0.69)\end{array}$ & $\begin{array}{l}-0.35 \\
(-1.94)\end{array}$ & $\begin{array}{l}-0.43^{* *} \\
(-2.79)\end{array}$ & $\begin{array}{l}-0.10 \\
(-0.81)\end{array}$ & $\begin{array}{l}-0.29^{*} \\
(-2.04)\end{array}$ & $\begin{array}{l}-0.31^{*} \\
(-2.03)\end{array}$ & $\begin{array}{l}-0.54^{* * *} \\
(-3.39)\end{array}$ & $\begin{array}{l}-0.25 \\
(-1.73)\end{array}$ & $\begin{array}{l}-0.19 \\
(-1.32)\end{array}$ \\
\hline Pop. & $\begin{array}{l}-0.041 \\
(-0.38)\end{array}$ & $\begin{array}{l}0.077 \\
(0.65)\end{array}$ & $\begin{array}{c}0.0089 \\
(0.08)\end{array}$ & $\begin{array}{l}0.22 \\
(1.72)\end{array}$ & $\begin{array}{l}0.18 \\
(1.63)\end{array}$ & $\begin{array}{l}0.044 \\
(0.40)\end{array}$ & $\begin{array}{l}-0.038 \\
(-0.35)\end{array}$ & $\begin{array}{l}-0.045 \\
(-0.39)\end{array}$ & $\begin{array}{l}-0.049 \\
(-0.54)\end{array}$ & $\begin{array}{l}-0.026 \\
(-0.24)\end{array}$ & $\begin{array}{l}-0.085 \\
(-0.81)\end{array}$ \\
\hline GDP & $\begin{array}{l}0.25^{* * *} \\
(4.94)\end{array}$ & $\begin{array}{l}0.28^{* * *} \\
(5.79)\end{array}$ & $\begin{array}{l}0.33^{* * *} \\
(4.94)\end{array}$ & $\begin{array}{l}0.16^{*} \\
(2.34)\end{array}$ & $\begin{array}{l}0.22^{* * *} \\
(4.30)\end{array}$ & $\begin{array}{l}0.24^{* * *} \\
(5.09)\end{array}$ & $\begin{array}{l}0.25^{* * *} \\
(4.85)\end{array}$ & $\begin{array}{l}0.25^{* * *} \\
(4.86)\end{array}$ & $\begin{array}{l}0.29^{* * *} \\
(5.64)\end{array}$ & $\begin{array}{l}0.23^{* * *} \\
(4.22)\end{array}$ & $\begin{array}{l}0.24^{* * * *} \\
(4.93)\end{array}$ \\
\hline PR & $\begin{array}{l}-0.11^{*} \\
(-2.32)\end{array}$ & $\begin{array}{l}-0.13^{* *} \\
(-2.64)\end{array}$ & $\begin{array}{l}-0.12^{*} \\
(-2.53)\end{array}$ & $\begin{array}{l}-0.059 \\
(-0.64)\end{array}$ & $\begin{array}{l}-0.085 \\
(-1.77)\end{array}$ & $\begin{array}{l}-0.14^{*} \\
(-2.44)\end{array}$ & $\begin{array}{l}-0.12^{*} \\
(-2.51)\end{array}$ & $\begin{array}{l}-0.11^{*} \\
(-2.21)\end{array}$ & $\begin{array}{c}0.0069 \\
(0.15)\end{array}$ & $\begin{array}{l}-0.087 \\
(-1.64)\end{array}$ & $\begin{array}{l}-0.11^{*} \\
(-2.56)\end{array}$ \\
\hline Mixed & $\begin{array}{l}-0.025 \\
-0.42)\end{array}$ & $\begin{array}{l}-0.049 \\
(-0.81)\end{array}$ & $\begin{array}{l}-0.034 \\
(-0.57)\end{array}$ & $\begin{array}{l}0.012 \\
(0.15)\end{array}$ & $\begin{array}{l}-0.011 \\
(-0.20)\end{array}$ & $\begin{array}{l}-0.047 \\
(-0.70)\end{array}$ & $\begin{array}{l}-0.026 \\
(-0.44)\end{array}$ & $\begin{array}{l}-0.022 \\
(-0.38)\end{array}$ & $\begin{array}{l}0.035 \\
(0.66)\end{array}$ & $\begin{array}{c}-0.0068 \\
(-0.11)\end{array}$ & $\begin{array}{l}-0.027 \\
(-0.50)\end{array}$ \\
\hline Urban & & $\begin{array}{c}-2.9 \mathrm{e}-09^{* * *} \\
(-5.82)\end{array}$ & & & & & & & & & \\
\hline Openness & & & $\begin{array}{c}-0.0039^{* *} \\
(-2.90)\end{array}$ & & & & & & & & \\
\hline Inc, ineq. & & & & $\begin{array}{c}-0.0030^{*} \\
(-2.13)\end{array}$ & & & & & & & \\
\hline Fam. farms & & & & & $\begin{array}{c}0.0057^{* * *} \\
(4.94)\end{array}$ & & & & & & \\
\hline Union den. & & & & & & $\begin{array}{c}0.0050^{* * *} \\
(4.58)\end{array}$ & & & & & \\
\hline Left & & & & & & & $\begin{array}{l}0.038 \\
(1.88)\end{array}$ & & & & \\
\hline Corruption & & & & & & & & $\begin{array}{l}-0.062 \\
(-0.18)\end{array}$ & & & \\
\hline Imp. Admin. & & & & & & & & & $\begin{array}{l}0.13^{* * *} \\
(4.13)\end{array}$ & & \\
\hline Women pol. & & & & & & & & & & $\begin{array}{c}-0.13 \\
(-1.20)\end{array}$ & \\
\hline Civil society & & & & & & & & & & & $\begin{array}{l}-0.55^{* *} \\
(-2.95)\end{array}$ \\
\hline Country FE & Yes & Yes & Yes & Yes & Yes & Yes & Yes & Yes & Yes & Yes & Yes \\
\hline Year FE & Yes & Yes & Yes & Yes & Yes & Yes & Yes & Yes & Yes & Yes & Yes \\
\hline Observations & 267 & 267 & 263 & 188 & 267 & 254 & 267 & 267 & 267 & 267 & 267 \\
\hline
\end{tabular}


Table A26. Party institutionalization and social expenditures as share of GDP (from CPDS) including one control at a time

\begin{tabular}{|c|c|c|c|c|c|c|c|c|c|c|c|}
\hline & (1) & $(2)$ & (3) & (4) & (5) & (6) & (7) & (8) & (9) & $(10)$ & (11) \\
\hline Party Instit. & $\begin{array}{c}3.69 \\
(1.79)\end{array}$ & $\begin{array}{c}3.67 \\
(1.78)\end{array}$ & $\begin{array}{c}3.99 \\
(1.95)\end{array}$ & $\begin{array}{c}4.14 \\
(1.74)\end{array}$ & $\begin{array}{c}3.64 \\
(1.77)\end{array}$ & $\begin{array}{c}-2.80 \\
(-0.77)\end{array}$ & $\begin{array}{l}4.50^{*} \\
(1.98)\end{array}$ & $\begin{array}{c}-4.26 \\
(-1.70)\end{array}$ & $\begin{array}{l}5.84^{* *} \\
(2.74)\end{array}$ & $\begin{array}{l}4.51^{*} \\
(2.26)\end{array}$ & $\begin{array}{c}-0.27 \\
(-0.12)\end{array}$ \\
\hline Polyarchy & $\begin{array}{c}1.61 \\
(1.36)\end{array}$ & $\begin{array}{c}1.62 \\
(1.36)\end{array}$ & $\begin{array}{c}1.54 \\
(1.33)\end{array}$ & $\begin{array}{c}0.96 \\
(0.71)\end{array}$ & $\begin{array}{c}1.76 \\
(1.46)\end{array}$ & $\begin{array}{l}4.68^{* *} \\
(2.81)\end{array}$ & $\begin{array}{c}1.32 \\
(0.98)\end{array}$ & $\begin{array}{c}1.17 \\
(1.01)\end{array}$ & $\begin{array}{l}2.55^{*} \\
(2.12)\end{array}$ & $\begin{array}{l}3.80^{* *} \\
(2.82)\end{array}$ & $\begin{array}{l}-1.79 \\
(-1.26)\end{array}$ \\
\hline Pop. & $\begin{array}{c}-4.43^{* * *} \\
(-5.39)\end{array}$ & $\begin{array}{c}-4.41^{* * *} \\
(-5.24)\end{array}$ & $\begin{array}{l}-4.20^{* * *} \\
(-5.38)\end{array}$ & $\begin{array}{c}-4.36^{* * *} \\
(-5.13)\end{array}$ & $\begin{array}{c}-4.50^{* * *} \\
(-5.22)\end{array}$ & $\begin{array}{c}-4.11^{* * *} \\
(-4.61)\end{array}$ & $\begin{array}{l}-10.5^{* * *} \\
(-9.91)\end{array}$ & $\begin{array}{c}-5.29^{* * *} \\
(-6.18)\end{array}$ & $\begin{array}{c}-3.85^{* * *} \\
(-4.79)\end{array}$ & $\begin{array}{c}-3.46^{* * *} \\
(-4.68)\end{array}$ & $\begin{array}{l}-4.35^{\text {**** }} \\
(-5.30)\end{array}$ \\
\hline GDP & $\begin{array}{c}0.88 \\
(1.06)\end{array}$ & $\begin{array}{c}0.88 \\
(1.06)\end{array}$ & $\begin{array}{c}0.98 \\
(1.18)\end{array}$ & $\begin{array}{c}-0.78 \\
(-0.77)\end{array}$ & $\begin{array}{c}1.10 \\
(1.26)\end{array}$ & $\begin{array}{c}0.87 \\
(1.04)\end{array}$ & $\begin{array}{l}-0.52 \\
(-0.59)\end{array}$ & $\begin{array}{c}1.50 \\
(1.80)\end{array}$ & $\begin{array}{c}0.62 \\
(0.76)\end{array}$ & $\begin{array}{c}0.34 \\
(0.41)\end{array}$ & $\begin{array}{c}-0.46 \\
(-0.52)\end{array}$ \\
\hline PR & $\begin{array}{l}-1.29^{*} \\
(-2.17)\end{array}$ & $\begin{array}{l}-1.29^{*} \\
(-2.17)\end{array}$ & $\begin{array}{l}-1.71^{* *} \\
(-2.80)\end{array}$ & $\begin{array}{l}-2.79^{* * *} \\
(-3.71)\end{array}$ & $\begin{array}{l}-1.36^{*} \\
(-2.31)\end{array}$ & $\begin{array}{l}-0.045 \\
(-0.06)\end{array}$ & $\begin{array}{l}-0.66 \\
(-1.15)\end{array}$ & $\begin{array}{l}-2.25^{* * *} \\
(-4.04)\end{array}$ & $\begin{array}{l}-1.80^{* *} \\
(-2.88)\end{array}$ & $\begin{array}{l}-1.24^{*} \\
(-2.01)\end{array}$ & $\begin{array}{l}-1.06 \\
(-1.84)\end{array}$ \\
\hline Mixed & $\begin{array}{c}-1.70^{* *} \\
(-3.26)\end{array}$ & $\begin{array}{l}-1.70^{* *} \\
(-3.23)\end{array}$ & $\begin{array}{c}-1.93^{* * *} \\
(-3.55)\end{array}$ & $\begin{array}{c}-2.78^{* * *} \\
(-4.33)\end{array}$ & $\begin{array}{c}-1.74^{* * *} \\
(-3.38)\end{array}$ & $\begin{array}{l}-0.82 \\
(-1.40)\end{array}$ & $\begin{array}{l}-1.35^{* *} \\
(-2.73)\end{array}$ & $\begin{array}{c}-1.85^{* * *} \\
(-3.53)\end{array}$ & $\begin{array}{c}-1.82^{* * *} \\
(-3.36)\end{array}$ & $\begin{array}{l}-1.44^{* *} \\
(-2.74)\end{array}$ & $\begin{array}{l}-2.20^{\text {**** }} \\
(-4.11)\end{array}$ \\
\hline Urban & & $\begin{array}{c}-1.1 \mathrm{e}-09 \\
(-0.21)\end{array}$ & & & & & & & & & \\
\hline Openness & & & $\begin{array}{c}-0.034^{* * *} \\
(-3.65)\end{array}$ & & & & & & & & \\
\hline Inc, ineq. & & & & $\begin{array}{c}-0.030^{*} \\
(-2.41)\end{array}$ & & & & & & & \\
\hline Fam. farms & & & & & $\begin{array}{l}-0.013 \\
(-1.01)\end{array}$ & & & & & & \\
\hline Union den. & & & & & & $\begin{array}{c}0.044^{* * *} \\
(4.78)\end{array}$ & & & & & \\
\hline Left & & & & & & & $\begin{array}{l}-0.38^{*} \\
(-2.32)\end{array}$ & & & & \\
\hline Corruption & & & & & & & & $\begin{array}{l}-19.4^{* * *} \\
(-6.79)\end{array}$ & & & \\
\hline Imp. Admin. & & & & & & & & & $\begin{array}{c}-0.91^{* * *} \\
(-4.00)\end{array}$ & & \\
\hline Women pol. & & & & & & & & & & $\begin{array}{c}-3.96^{* * *} \\
(-4.37)\end{array}$ & \\
\hline Civil society & & & & & & & & & & & $\begin{array}{c}7.28^{* * *} \\
(4.02)\end{array}$ \\
\hline Country FE & Yes & Yes & Yes & Yes & Yes & Yes & Yes & Yes & Yes & Yes & Yes \\
\hline Year FE & Yes & Yes & Yes & Yes & Yes & Yes & Yes & Yes & Yes & Yes & Yes \\
\hline Observations & 781 & 781 & 781 & 741 & 781 & 737 & 739 & 781 & 781 & 775 & 781 \\
\hline
\end{tabular}


Table A27. Party institutionalization and Public Goods (v2dlencmps from V-Dem) including one control at a time

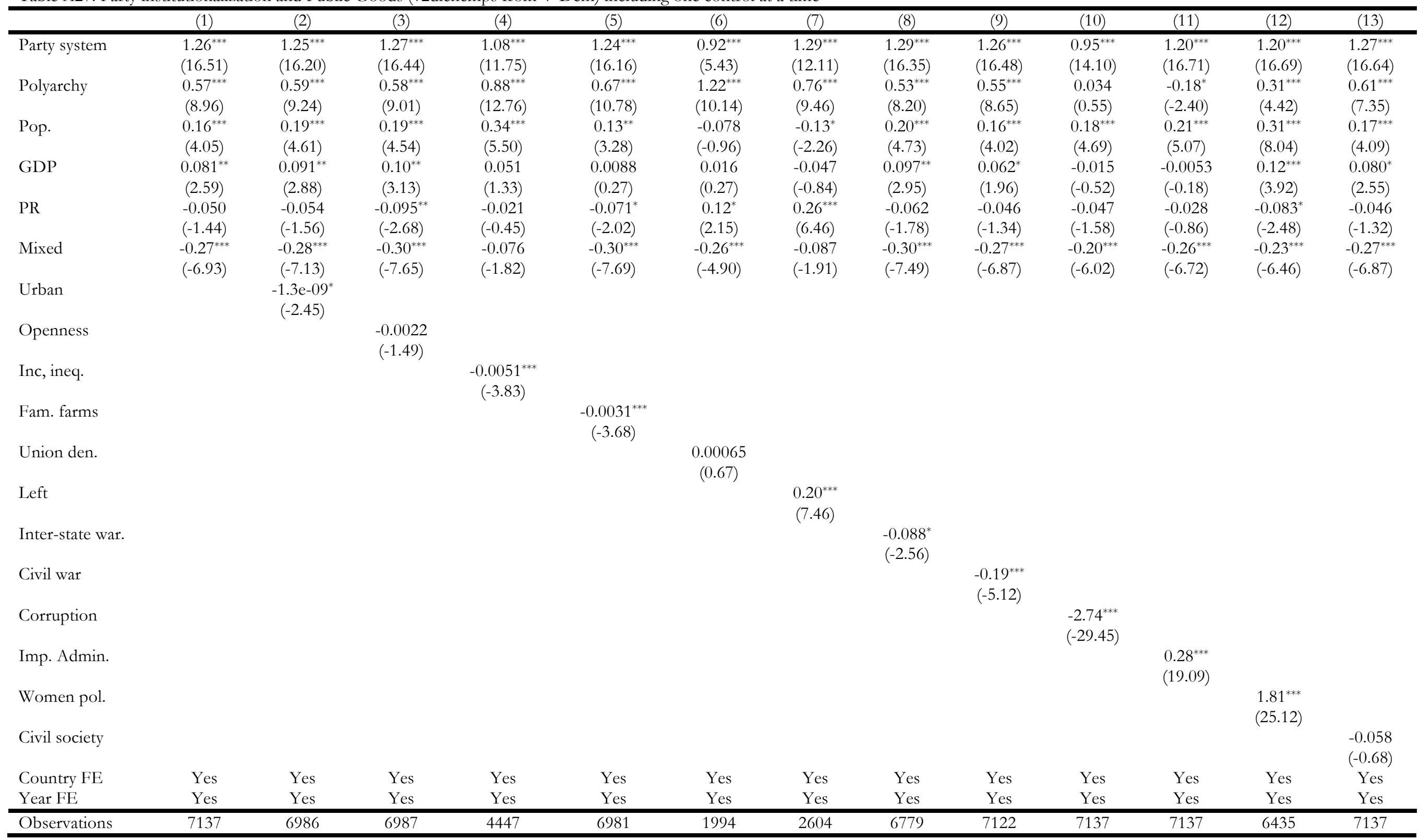

T-values (in parentheses) calculated with panel corrected standard errors. ${ }^{*} p<0.05,{ }^{* *} p<0.01,{ }^{* * *} p<0.001$ 


\section{Appendix A7: Replicating core heterogeneity tests (from Table 4 in paper) for alternative welfare measures}

Table A28. Party institutionalization on coverage of major welfare risks (Encompassingness; SPAW)

\begin{tabular}{|c|c|c|c|c|c|c|}
\hline Sample: & $\begin{array}{c}\text { (1) } \\
\text { Autocratic }\end{array}$ & $\begin{array}{c}(2) \\
\text { Democratic }\end{array}$ & $\begin{array}{c}(3) \\
\text { Western } \\
\text { countries }\end{array}$ & $\begin{array}{c}\text { (4) } \\
\text { Non-western } \\
\text { countries }\end{array}$ & $\begin{array}{l}\text { (5) } \\
\text { Low rural } \\
\text { inequality }\end{array}$ & $\begin{array}{l}\text { (6) } \\
\text { High rural } \\
\text { inequality }\end{array}$ \\
\hline Party Institut. & 0.0088 & $1.40^{* * *}$ & $1.39^{* * *}$ & $0.28^{* * *}$ & $0.86^{* * *}$ & 0.052 \\
\hline & $(0.10)$ & $(7.65)$ & $(6.81)$ & $(3.69)$ & $(7.87)$ & $(0.51)$ \\
\hline Population (ln) & $\begin{array}{l}0.65^{* * *} \\
(7.43)\end{array}$ & $\begin{array}{l}1.19^{* * *} \\
(16.71)\end{array}$ & $\begin{array}{l}1.11^{* * *} \\
(8.91)\end{array}$ & $\begin{array}{l}0.61^{* * *} \\
(10.79)\end{array}$ & $\begin{array}{l}1.03^{* * *} \\
(13.70)\end{array}$ & $\begin{array}{l}0.57^{* * *} \\
(6.33)\end{array}$ \\
\hline GDP p.c. (ln) & $\begin{array}{l}-0.074 \\
(-1.80)\end{array}$ & $\begin{array}{l}-0.18^{*} \\
(-2.50)\end{array}$ & $\begin{array}{c}0.16 \\
(1.55)\end{array}$ & $\begin{array}{l}0.20^{* * * *} \\
(5.06)\end{array}$ & $\begin{array}{l}0.53^{* * *} \\
(10.91)\end{array}$ & $\begin{array}{l}-0.24^{* *} \\
(-3.18)\end{array}$ \\
\hline PR & $\begin{array}{l}0.41^{* * *} \\
(8.81)\end{array}$ & $\begin{array}{l}0.87^{* * *} \\
(12.26)\end{array}$ & $\begin{array}{l}0.52^{* * *} \\
(7.05)\end{array}$ & $\begin{array}{l}0.51^{* * *} \\
(13.45)\end{array}$ & $\begin{array}{l}0.21^{* * *} \\
(5.00)\end{array}$ & $\begin{array}{l}0.73^{* * *} \\
(15.44)\end{array}$ \\
\hline Mixed & $\begin{array}{l}0.54^{* * *} \\
(9.00)\end{array}$ & $\begin{array}{l}0.60^{* * *} \\
(5.05)\end{array}$ & $\begin{array}{l}0.63^{* * *} \\
(6.12)\end{array}$ & $\begin{array}{l}0.43^{* * *} \\
(8.66)\end{array}$ & $\begin{array}{c}0.11 \\
(1.88)\end{array}$ & $\begin{array}{l}0.62^{* * *} \\
(9.30)\end{array}$ \\
\hline Polyarchy & & & $\begin{array}{l}-1.26^{* * *} \\
(-7.91)\end{array}$ & $\begin{array}{l}-0.19^{*} \\
(-2.48)\end{array}$ & $\begin{array}{l}-0.42^{* * *} \\
(-4.86)\end{array}$ & $\begin{array}{l}-0.48^{* * *} \\
(-4.57)\end{array}$ \\
\hline Country Dummies & Yes & Yes & Yes & Yes & Yes & Yes \\
\hline Year Dummies & Yes & Yes & Yes & Yes & Yes & Yes \\
\hline Observations & 3378 & 2767 & 1558 & 4596 & 3596 & 2474 \\
\hline
\end{tabular}

T-values (in parentheses) calculated with panel corrected standard errors. ${ }^{*} p<0.05,{ }^{* *} p<0.01,{ }^{* * *} p<0.001$ 
Table A29. Testing for heterogeneity: Party institutionalization and SPAW Universalism Index

\begin{tabular}{|c|c|c|c|c|c|c|}
\hline Sample: & $\begin{array}{c}(1) \\
\text { Autocratic }\end{array}$ & $\begin{array}{c}(2) \\
\text { Democratic }\end{array}$ & $\begin{array}{c}(3) \\
\text { Western } \\
\text { countries }\end{array}$ & $\begin{array}{c}(4) \\
\text { Non-western } \\
\text { countries }\end{array}$ & $\begin{array}{l}\text { (5) } \\
\text { Low rural } \\
\text { inequality }\end{array}$ & $\begin{array}{l}\text { (6) } \\
\text { High rural } \\
\text { inequality }\end{array}$ \\
\hline Party Institut. & $1.07^{* *}$ & 1.28 & $6.97^{* * *}$ & $1.57^{* * *}$ & $2.29^{* * *}$ & $3.59^{* * *}$ \\
\hline & $(2.66)$ & $(0.85)$ & $(3.66)$ & (3.78) & $(4.19)$ & $(5.91)$ \\
\hline Population (ln) & $\begin{array}{l}1.53^{* * *} \\
(3.34)\end{array}$ & $\begin{array}{l}3.19^{* * *} \\
(4.85)\end{array}$ & $\begin{array}{c}1.62 \\
(1.25)\end{array}$ & $\begin{array}{l}0.98^{* *} \\
(2.63)\end{array}$ & $\begin{array}{c}0.90 \\
(1.38)\end{array}$ & $\begin{array}{l}-2.50^{* * *} \\
(-4.35)\end{array}$ \\
\hline GDP p.c. (ln) & $\begin{array}{c}-0.0037 \\
(-0.02)\end{array}$ & $\begin{array}{l}1.92^{* *} \\
(2.71)\end{array}$ & $\begin{array}{l}4.84^{* * *} \\
(4.51)\end{array}$ & $\begin{array}{l}0.072 \\
(0.31)\end{array}$ & $\begin{array}{l}2.11^{* * *} \\
(8.00)\end{array}$ & $\begin{array}{l}-2.65^{\text {*** }} \\
(-5.42)\end{array}$ \\
\hline PR & $\begin{array}{l}0.40^{*} \\
(1.96)\end{array}$ & $\begin{array}{l}-0.039 \\
(-0.07)\end{array}$ & $\begin{array}{l}-1.75^{*} \\
(-2.30)\end{array}$ & $\begin{array}{l}0.69^{* * *} \\
(3.33)\end{array}$ & $\begin{array}{l}1.09^{* * *} \\
(3.56)\end{array}$ & $\begin{array}{c}0.44 \\
(1.52)\end{array}$ \\
\hline Mixed & $\begin{array}{l}2.22^{* * *} \\
(6.47)\end{array}$ & $\begin{array}{c}1.14 \\
(1.26)\end{array}$ & $\begin{array}{l}-1.76 \\
(-1.95)\end{array}$ & $\begin{array}{l}2.59^{* * *} \\
(8.09)\end{array}$ & $\begin{array}{c}0.58 \\
(1.13)\end{array}$ & $\begin{array}{l}1.66^{* * *} \\
(3.47)\end{array}$ \\
\hline Polyarchy & & & $\begin{array}{l}-6.88^{* * *} \\
(-4.34)\end{array}$ & $\begin{array}{l}1.89^{* * * *} \\
(4.26)\end{array}$ & $\begin{array}{l}-0.85 \\
(-1.43)\end{array}$ & $\begin{array}{l}0.084 \\
(0.13)\end{array}$ \\
\hline Country Dummies & Yes & Yes & Yes & Yes & Yes & Yes \\
\hline Year Dummies & Yes & Yes & Yes & Yes & Yes & Yes \\
\hline Observations & 2524 & 1646 & 820 & 3352 & 2245 & 1855 \\
\hline
\end{tabular}

T-values (in parentheses) calculated with panel corrected standard errors. ${ }^{*} p<0.05,{ }^{* *} p<0.01,{ }^{* * *} p<0.001$ 
Table A30. Testing for heterogeneity: Party institutionalization and Public Goods (v2dlencmps; V-Dem)

\begin{tabular}{|c|c|c|c|c|c|c|}
\hline Sample: & $\begin{array}{c}\text { (1) } \\
\text { Autocratic }\end{array}$ & $\begin{array}{c}(2) \\
\text { Democratic }\end{array}$ & $\begin{array}{c}(3) \\
\text { Western } \\
\text { countries }\end{array}$ & $\begin{array}{c}(4) \\
\text { Non-western } \\
\text { countries }\end{array}$ & $\begin{array}{l}\text { (5) } \\
\text { Low rural } \\
\text { inequality }\end{array}$ & $\begin{array}{l}\text { (6) } \\
\text { High rural } \\
\text { inequality }\end{array}$ \\
\hline Party Institut. & $1.12^{* * *}$ & $1.68^{* * *}$ & $1.19^{* * *}$ & $1.17^{* * *}$ & $1.53^{* * *}$ & $1.32^{* * *}$ \\
\hline & (11.19) & (12.88) & (7.98) & (13.94) & (15.35) & (11.33) \\
\hline Population (ln) & $\begin{array}{l}-0.015 \\
-0.18)\end{array}$ & $\begin{array}{c}-0.33^{* * *} \\
(-6.21)\end{array}$ & $\begin{array}{c}-0.44^{* * *} \\
(-4.82)\end{array}$ & $\begin{array}{c}0.41^{* * *} \\
(6.99)\end{array}$ & $\begin{array}{l}0.012 \\
(0.21)\end{array}$ & $\begin{array}{c}0.12 \\
(1.34)\end{array}$ \\
\hline GDP p.c. $(\ln )$ & $\begin{array}{l}-0.070 \\
(-1.68)\end{array}$ & $\begin{array}{l}0.095^{*} \\
(2.06)\end{array}$ & $\begin{array}{l}0.36^{* * *} \\
(4.33)\end{array}$ & $\begin{array}{l}0.028 \\
(0.83)\end{array}$ & $\begin{array}{l}0.17^{* * *} \\
(4.41)\end{array}$ & $\begin{array}{c}-0.0049 \\
(-0.08)\end{array}$ \\
\hline PR & $\begin{array}{l}-0.059 \\
(-1.21)\end{array}$ & $\begin{array}{l}0.068 \\
(1.51)\end{array}$ & $\begin{array}{l}-0.073 \\
(-1.46)\end{array}$ & $\begin{array}{l}-0.13^{* *} \\
(-3.06)\end{array}$ & $\begin{array}{l}-0.20^{* * *} \\
(-4.31)\end{array}$ & $\begin{array}{l}-0.045 \\
(-0.91)\end{array}$ \\
\hline Mixed & $\begin{array}{l}-0.15^{* *} \\
(-2.70)\end{array}$ & $\begin{array}{l}-0.086 \\
-1.67)\end{array}$ & $\begin{array}{l}-0.19^{* *} \\
(-3.06)\end{array}$ & $\begin{array}{c}-0.25^{* * *} \\
(-5.57)\end{array}$ & $\begin{array}{l}-0.12^{*} \\
(-2.18)\end{array}$ & $\begin{array}{c}-0.54^{* * * *} \\
(-9.37)\end{array}$ \\
\hline Polyarchy & & & $\begin{array}{l}1.24^{* * *} \\
(10.32)\end{array}$ & $\begin{array}{l}0.37^{* * * *} \\
(4.98)\end{array}$ & $\begin{array}{l}0.76^{* * *} \\
(8.53)\end{array}$ & $\begin{array}{c}0.16 \\
(1.61)\end{array}$ \\
\hline $\begin{array}{l}\text { Country } \\
\text { Dummies }\end{array}$ & Yes & Yes & Yes & Yes & Yes & Yes \\
\hline Year Dummies & Yes & Yes & Yes & Yes & Yes & Yes \\
\hline Observations & 3981 & 3137 & 1718 & 5419 & 4167 & 2885 \\
\hline
\end{tabular}

T-values (in parentheses) calculated with panel corrected standard errors. ${ }^{*} p<0.05,{ }^{* *} p<0.01,{ }^{* * *} p<0.001$ 


\section{Appendix A8: Tests using alternative PI measure, omitting party linkages indicator}

Table A31. Version of Party Institutionalization calculated without v2psprlnks regressed on various welfare measures

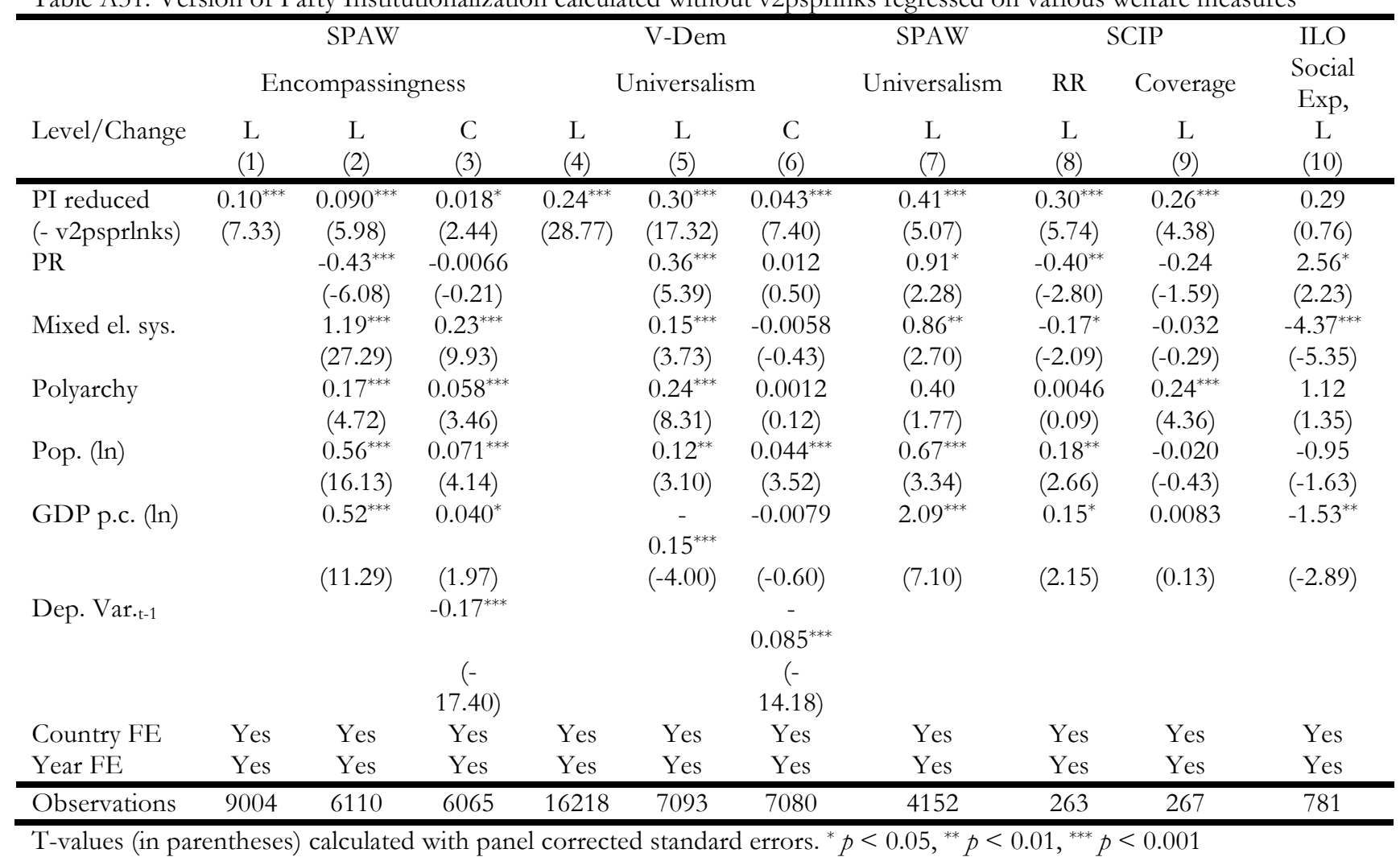




\section{Appendix A9: Placebo tests}

Table A32. Placebo tests on v2dlunivl (from V-Dem)

\begin{tabular}{|c|c|c|c|c|c|c|}
\hline \multirow[t]{2}{*}{ Dep var. } & \multicolumn{3}{|c|}{$\begin{array}{c}\text { Military Expenditure } \\
(\% \text { of GDP) }\end{array}$} & \multicolumn{3}{|c|}{$\begin{array}{c}\text { Expenditures for Public Order } \\
(\% \text { of GDP })\end{array}$} \\
\hline & $(1)$ & $(2)$ & (3) & (4) & (5) & (6) \\
\hline Party Institut. & $\begin{array}{l}-1.01^{* *} \\
(-2.81)\end{array}$ & $\begin{array}{c}0.16 \\
(0.39)\end{array}$ & $\begin{array}{c}0.13 \\
(0.50)\end{array}$ & $\begin{array}{c}-0.0051^{*} \\
(-2.38)\end{array}$ & $\begin{array}{c}-0.0015 \\
(-0.63)\end{array}$ & $\begin{array}{c}0.00034 \\
(0.17)\end{array}$ \\
\hline Polyarchy & & $\begin{array}{l}-1.62^{* * *} \\
(-5.80)\end{array}$ & $\begin{array}{l}-0.19 \\
(-0.82)\end{array}$ & & $\begin{array}{c}-0.0023 \\
(-0.94)\end{array}$ & $\begin{array}{c}-0.0015 \\
(-0.67)\end{array}$ \\
\hline Population & & $\begin{array}{l}-0.013 \\
(-0.04)\end{array}$ & $\begin{array}{c}0.11 \\
(0.43)\end{array}$ & & $\begin{array}{c}-0.0093^{* *} \\
(-2.70)\end{array}$ & $\begin{array}{c}-0.00023 \\
(-0.08)\end{array}$ \\
\hline GDP & & $\begin{array}{c}0.25 \\
(0.68)\end{array}$ & $\begin{array}{c}0.42 \\
(1.45)\end{array}$ & & $\begin{array}{l}-0.0039^{* * *} \\
(-4.35)\end{array}$ & $\begin{array}{c}-0.00090 \\
(-1.24)\end{array}$ \\
\hline PR & & $\begin{array}{l}-0.089 \\
(-0.37)\end{array}$ & $\begin{array}{l}-0.34^{*} \\
(-2.25)\end{array}$ & & $\begin{array}{c}0.0026^{* *} \\
(2.74)\end{array}$ & $\begin{array}{c}0.00039 \\
(0.46)\end{array}$ \\
\hline Mixed & & $\begin{array}{c}0.17 \\
(1.35)\end{array}$ & $\begin{array}{l}-0.078 \\
(-0.81)\end{array}$ & & $\begin{array}{c}0.0023 \\
(1.55)\end{array}$ & $\begin{array}{c}0.00017 \\
(0.16)\end{array}$ \\
\hline Lvd & & & $\begin{array}{l}-0.37^{* * * *} \\
(-4.26)\end{array}$ & & & $\begin{array}{c}-0.37^{* * *} \\
(-8.23)\end{array}$ \\
\hline Country FE & Yes & Yes & Yes & Yes & Yes & Yes \\
\hline Year FE & Yes & Yes & Yes & Yes & Yes & Yes \\
\hline Observations & 3028 & 1919 & 1763 & 854 & 721 & 623 \\
\hline
\end{tabular}




\section{Appendix A10: Additional tests for heterogeneity}

Table A33. Party institutionalization and universalism (v2dlunivl from V-Dem), split sample according to income inequality Gini coefficients.

\begin{tabular}{|c|c|c|}
\hline & $\begin{array}{c}\text { (1) } \\
\text { High Inequality }\end{array}$ & $\begin{array}{c}\text { (2) } \\
\text { Low } \\
\text { Inequality }\end{array}$ \\
\hline Party institutionalization & $\begin{array}{l}1.21^{* * *} \\
(14.63)\end{array}$ & $\begin{array}{l}1.99^{* * *} \\
(11.78)\end{array}$ \\
\hline Population & $\begin{array}{l}0.37^{* * *} \\
(4.85)\end{array}$ & $\begin{array}{l}0.20^{*} \\
(2.19)\end{array}$ \\
\hline GDP & $\begin{array}{l}0.13^{*} \\
(2.06)\end{array}$ & $\begin{array}{l}1.07^{* * *} \\
(13.88)\end{array}$ \\
\hline PR & $\begin{array}{l}0.11^{* *} \\
(2.86)\end{array}$ & $\begin{array}{l}0.68^{* * *} \\
(14.16)\end{array}$ \\
\hline Mixed & $\begin{array}{l}0.070 \\
(1.82)\end{array}$ & $\begin{array}{l}-0.30^{* * *} \\
(-4.69)\end{array}$ \\
\hline $\begin{array}{l}\text { Country FE } \\
\text { Year FE }\end{array}$ & $\begin{array}{l}\text { Yes } \\
\text { Yes }\end{array}$ & $\begin{array}{l}\text { Yes } \\
\text { Yes }\end{array}$ \\
\hline Observations & 4893 & 2235 \\
\hline
\end{tabular}


Table A34. Party institutionalization and universalism (v2dlunivl: V-Dem). Interaction specifications.

\begin{tabular}{lccc} 
& $(1)$ & $(2)$ & $(3)$ \\
& Rural inequality & Income inequality & Western vs other countries \\
\hline Party inst. & $1.97^{* * *}$ & $1.39^{* *}$ & $\left(6.89^{* * *}\right.$ \\
& $(8.09)$ & $(2.79)$ & $(9)$ \\
Fam. Farms & 0.0042 & & \\
& $(1.41)$ & & $-0.034^{* *}$ \\
Party inst. ${ }^{*}$ Fam. farms & 0.0014 & $(-2.70)$ & 0.018 \\
Income ineq. & $(0.33)$ & $(1.18)$ & $-6.97^{* * *}$ \\
Party inst.*Income ineq. & & & $(-27.87)$ \\
& & & $4.39^{* * *}$ \\
West & & & $(20.91)$ \\
Western dummy*Party inst. & & Yes & Yes \\
Country Dummies & & Yes & 2235 \\
Year Dummies & Yes & 2235 & Yes \\
\hline Observations & 2199 & & \\
\hline
\end{tabular}

T-values (in parentheses) calculated with panel corrected standard errors. Constant, year- and country-fixed effects, and controls (GDP [Log], population [Log], Polyarchy index, electoral system dummies) omitted from table. ${ }^{*} p<0.05,{ }^{* *} p<$ $0.01,{ }^{* * *} p<0.001$ 
Table A35. Party institutionalization on universalism (v2dlunivl from V-Dem), omitting regions from sample

\begin{tabular}{|c|c|c|c|c|c|c|c|c|c|c|c|}
\hline $\begin{array}{l}\text { Region } \\
\text { excluded }\end{array}$ & $\begin{array}{c}(1) \\
\text { All } \\
\text { include } \\
\text { d }\end{array}$ & $\begin{array}{c}\text { (2) } \\
\text { East. } \\
\text { Europ } \\
\mathrm{e}\end{array}$ & $\begin{array}{c}\text { (3) } \\
\text { Lat. } \\
\text { Amer. }\end{array}$ & $\begin{array}{c}(4) \\
\mathrm{MEN} \\
\mathrm{A}\end{array}$ & $\begin{array}{c}\text { (5) } \\
\text { Sub- } \\
\text { Sa. } \\
\text { Africa. }\end{array}$ & $\begin{array}{c}\text { (6) } \\
\text { West }\end{array}$ & $\begin{array}{c}\text { (7) } \\
\text { East. } \\
\text { Asia }\end{array}$ & $\begin{array}{c}\text { (8) } \\
\text { South- } \\
\text { East } \\
\text { Asia }\end{array}$ & $\begin{array}{c}(9) \\
\text { South } \\
\text { Asia }\end{array}$ & $\begin{array}{c}(10) \\
\text { Pacific }\end{array}$ & $\begin{array}{c}(11) \\
\text { Caribbea } \\
\mathrm{n}\end{array}$ \\
\hline Party instit. & $\begin{array}{l}0.96^{* * *} \\
(12.30)\end{array}$ & $\begin{array}{c}0.96^{* * *} \\
(12.30)\end{array}$ & $\begin{array}{c}1.75^{\text {*** }} \\
(19.50 \\
)\end{array}$ & $\begin{array}{l}1.38^{* * *} \\
(16.08)\end{array}$ & $\begin{array}{c}1.40^{* * *} \\
(14.21 \\
)\end{array}$ & $\begin{array}{c}0.98^{* * *} \\
(11.94 \\
)\end{array}$ & $\begin{array}{c}1.31^{* * * *} \\
(16.22 \\
)\end{array}$ & $\begin{array}{c}1.22^{* * *} \\
(14.98 \\
)\end{array}$ & $\begin{array}{c}1.39^{* * *} \\
(17.01 \\
)\end{array}$ & $\begin{array}{c}1.30^{* * *} \\
(16.23 \\
)\end{array}$ & $\begin{array}{l}1.29^{* * *} \\
(16.10)\end{array}$ \\
\hline Country FE & Yes & Yes & Yes & Yes & Yes & Yes & Yes & Yes & Yes & Yes & Yes \\
\hline Year FE & Yes & Yes & Yes & Yes & Yes & Yes & Yes & Yes & Yes & Yes & Yes \\
\hline $\begin{array}{l}\text { Observation } \\
\mathrm{s}\end{array}$ & 6394 & 6394 & 5739 & 6497 & 5490 & 5419 & 6913 & 6766 & 6859 & 7137 & 7019 \\
\hline
\end{tabular}


Table A36. Party institutionalization on various welfare state measures, with sample restricted to Latin American countries V-Dem universalism SPAW SPAW universalism encompassingness

\begin{tabular}{|c|c|c|c|c|c|c|}
\hline & (1) & (2) & (3) & (4) & (5) & (6) \\
\hline Party instit. & $\begin{array}{c}0.82^{* * *} \\
(7.71)\end{array}$ & $\begin{array}{c}0.21 \\
(1.43)\end{array}$ & $\begin{array}{c}0.20^{*} \\
(2.01)\end{array}$ & $\begin{array}{l}0.32^{* *} \\
(2.61)\end{array}$ & $\begin{array}{l}1.29^{* *} \\
(2.64)\end{array}$ & $\begin{array}{l}4.80^{* * *} \\
(5.82)\end{array}$ \\
\hline Polyarchy & & $\begin{array}{l}0.46^{* *} \\
(3.29)\end{array}$ & & $\begin{array}{l}-0.30^{* *} \\
(-2.58)\end{array}$ & & $\begin{array}{l}-0.070 \\
(-0.09)\end{array}$ \\
\hline Population & & $\begin{array}{l}0.80^{* * *} \\
(6.51)\end{array}$ & & $\begin{array}{c}-0.17 \\
(-1.45)\end{array}$ & & $\begin{array}{l}-1.19 \\
(-1.28)\end{array}$ \\
\hline GDP & & $\begin{array}{c}-0.87^{* * *} \\
(-7.77)\end{array}$ & & $\begin{array}{c}-0.46^{* * *} \\
(-5.48)\end{array}$ & & $\begin{array}{l}-4.12^{* * *} \\
(-6.47)\end{array}$ \\
\hline PR & & $\begin{array}{l}0.49^{* * *} \\
(6.03)\end{array}$ & & $\begin{array}{l}0.74^{* * *} \\
(12.88)\end{array}$ & & $\begin{array}{c}0.0027 \\
(0.01)\end{array}$ \\
\hline Mixed & & $\begin{array}{c}0.37^{* * *} \\
(4.45)\end{array}$ & & $\begin{array}{c}0.36^{* * *} \\
(5.35)\end{array}$ & & $\begin{array}{c}2.66^{* * *} \\
(6.88)\end{array}$ \\
\hline Country Dummies & Yes & Yes & Yes & Yes & Yes & Yes \\
\hline Year Dummies & Yes & Yes & Yes & Yes & Yes & Yes \\
\hline Observations & 2159 & 1398 & 1838 & 1257 & 1377 & 999 \\
\hline
\end{tabular}

T-values calculated with panel corrected standard errors. ${ }^{*} p<0.05,{ }^{* *} p<0.01,{ }^{* * *} p<0.001$ 